SANDIA REPORT

SAND 2007-2654

Unclassified Unlimited Release

Printed June 2007

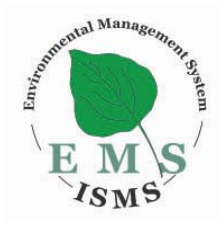

\title{
Site Environmental Report for 2006 Sandia National Laboratories, California
}

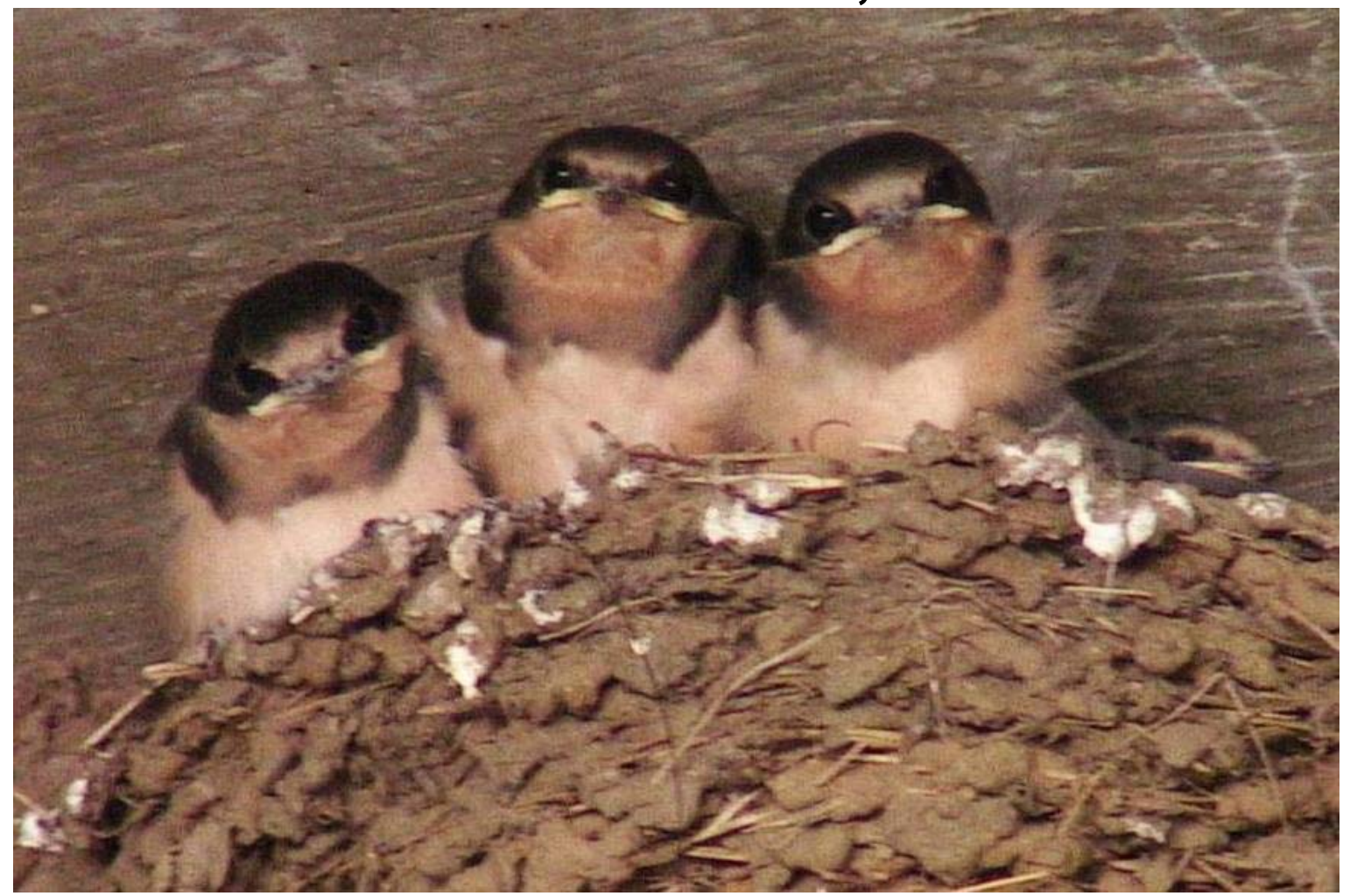

B.L. Larsen

Prepared by

Sandia National Laboratories

Livermore, California 94550

Sandia is a multiprogram laboratory operated by Sandia Corporation,

a Lockheed Martin Company, for the United States Department of Energy's

National Nuclear Security Administration under Contract DE-AC04-94AL85000.

Approved for public release; further dissemination unlimited. 
Issued by Sandia National Laboratories, operated for the United States Department of Energy by Sandia Corporation.

NOTICE: This report was prepared as an account of work sponsored by an agency of the United States Government. Neither the United States Government, nor any agency thereof, nor any of their employees, nor any of their contractors, subcontractors, or their employees, make any warranty, express or implied, or assume any legal liability or responsibility for the accuracy, completeness, or usefulness of any information, apparatus, product, or process disclosed, or represent that its use would not infringe privately owned rights. Reference herein to any specific commercial product, process, or service by trade name, trademark, manufacturer, or otherwise, does not necessarily constitute or imply its endorsement, recommendation, or favoring by the United States Government, any agency thereof, or any of their contractors or subcontractors. The views and opinions expressed herein do not necessarily state or reflect those of the United States Government, any agency thereof, or any of their contractors.

Printed in the United States of America. This report has been reproduced directly from the best available copy.

Available to DOE and DOE contractors from

U.S. Department of Energy

Office of Scientific and Technical Information

P.O. Box 62

Oak Ridge, TN 37831

Telephone: $\quad$ (865) 576-8401

Facsimile: (865) 576-5728

E-Mail:_reports@adonis.osti.gov

Online ordering: http://www.doe.gov/bridge

Available to the public from

U.S. Department of Commerce

National Technical Information Service

5285 Port Royal Road

Springfield, VA 22161

$\begin{array}{ll}\text { Telephone: } & \text { (800) 553-6847 } \\ \text { Facsimile: } & \text { (703) 605-6900 }\end{array}$

E-Mail:_orders@ntis.fedworld.gov

Online order: http://www.ntis.gov/ordering.htm
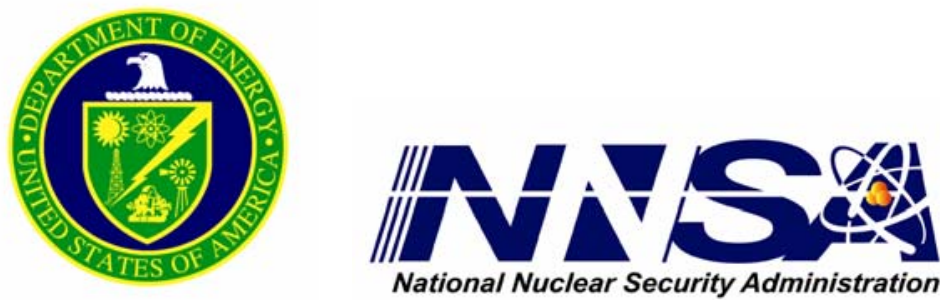
SAND 2007-2654

Unclassified Unlimited Release

Printed June 2007

\title{
Site Environmental Report for 2006 Sandia National Laboratories, California
}

\author{
Barbara L. Larsen \\ Environmental Management Department \\ Sandia National Laboratories, California \\ 7011 East Avenue \\ Livermore, CA 94550
}

\begin{abstract}
Sandia National Laboratories, California (SNL/CA) is a government-owned/contractoroperated laboratory. Sandia Corporation, a Lockheed Martin Company, operates the laboratory for the Department of Energy's National Nuclear Security Administration (NNSA). The NNSA Sandia Site Office oversees operations at the site, using Sandia Corporation as a management and operating contractor. This Site Environmental Report for 2006 was prepared in accordance with DOE Order 231.1A (DOE 2004a). The report provides a summary of environmental monitoring information and compliance activities that occurred at SNL/CA during calendar year 2006. General site and environmental program information is also included.
\end{abstract}




\title{
Acknowledgements
}

This report was prepared by the Sandia National Laboratories, California Environmental Management Department, and reviewed and approved by the Department of Energy, National Nuclear Security Administration, Sandia Site Office. The author acknowledges the following key contributors to the content, review, and production of this report.

\author{
Karen Agogino \\ Mark Brynildson \\ Laurie Farren \\ Leslee Gardizi \\ Janet Harris \\ Robert Holland \\ Jeff Irwin \\ Kristin Kerr \\ Sandy Leo \\ Joanne Mount-Sartor \\ Gary Shamber
}

Additional information about this report can be obtained from:

\author{
Sandia National Laboratories, California \\ Public and Media Relations Office \\ P.O. Box 969 \\ Livermore, CA 94551-0969 \\ Attention: Mike Janes \\ Phone: (925) 294-2447 \\ E-mail: mejanes@sandia.gov \\ Or \\ U.S. Department of Energy \\ National Nuclear Security Administration \\ Sandia Site Office \\ P.O. Box 5400 \\ Albuquerque, NM 87185-5400 \\ Attention: Karen Agogino \\ Phone: (505) 845-6100 \\ E-mail: kagogino@doeal.gov
}




\section{Contents}

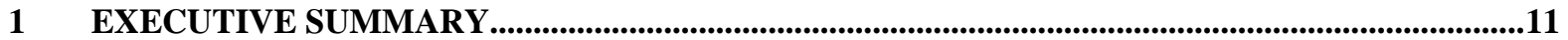

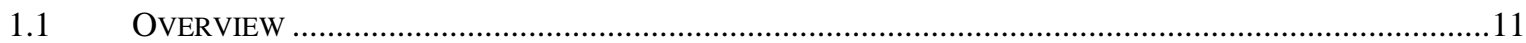

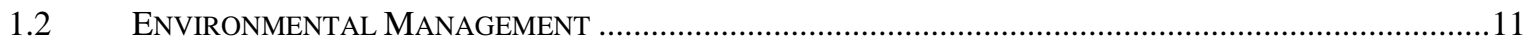

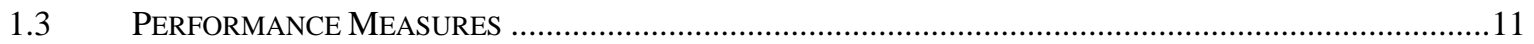

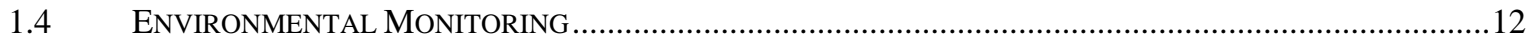

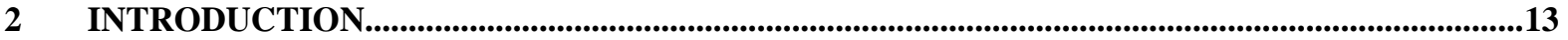

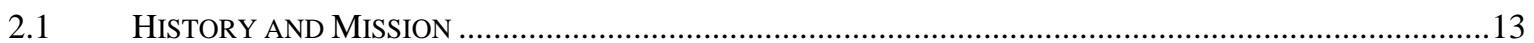

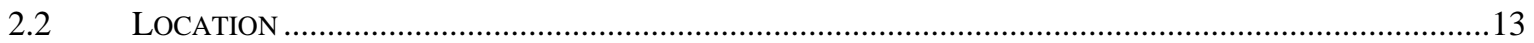

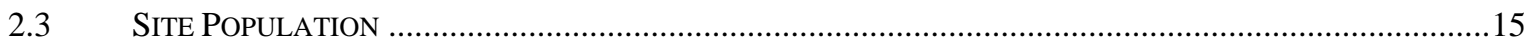

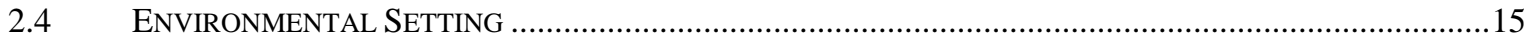

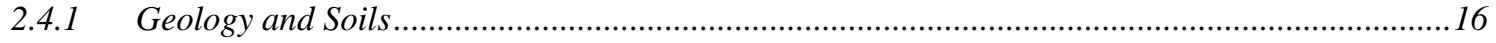

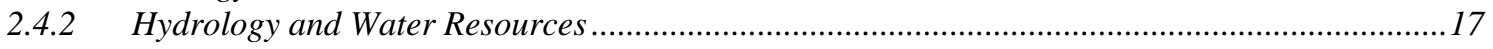

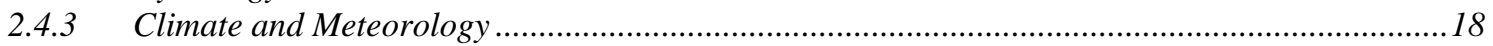

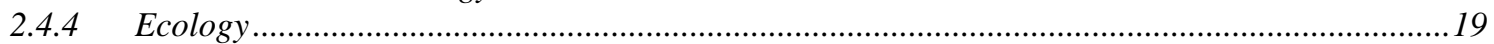

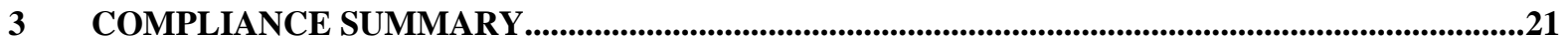

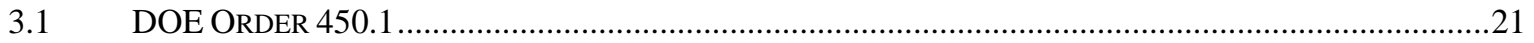

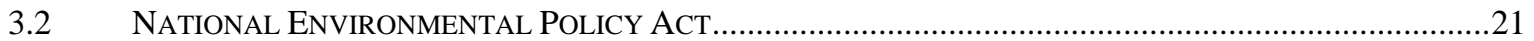

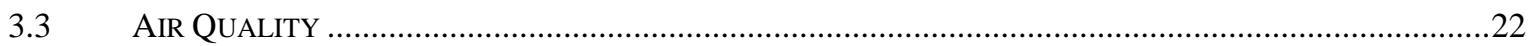

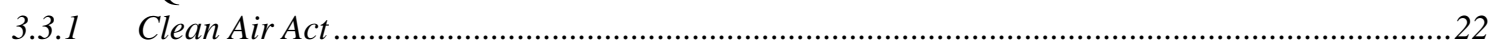

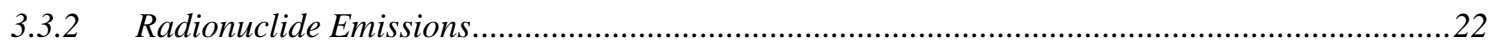

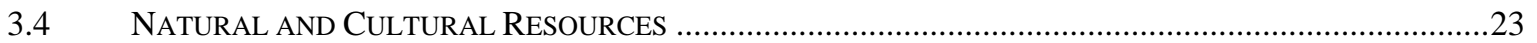

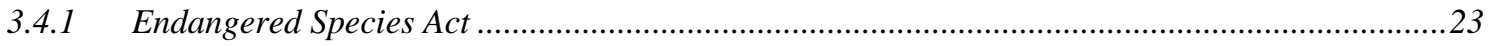

3.4.2 Interim Protections for California Red-legged Frogs ..................................................................23

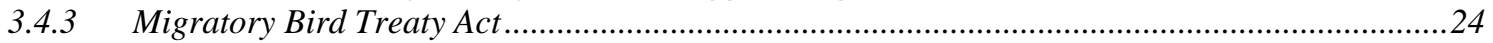

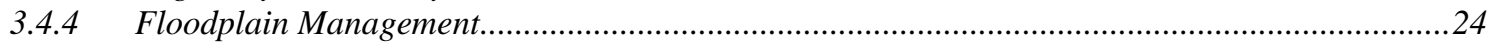

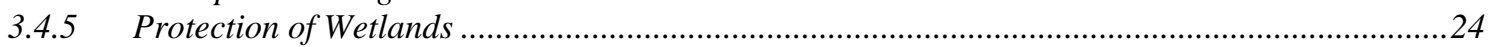

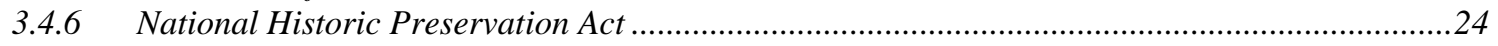

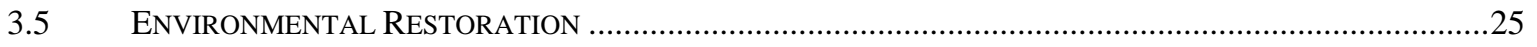

3.5.1 Comprehensive Environmental Response, Compensation, and Liability Act ...............................25

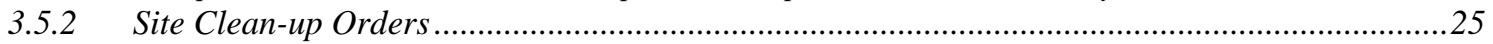

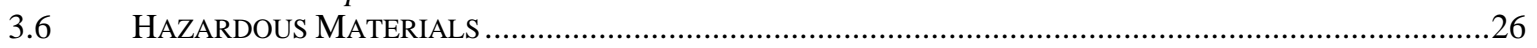

3.6.1 Emergency Planning and Community Right-to-Know Act...........................................................26

3.6.2 California Hazardous Materials Release Response Plans and Inventory Law ...........................26

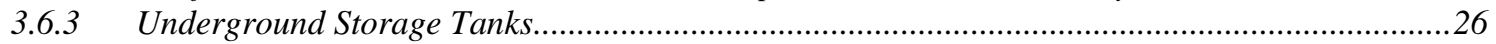

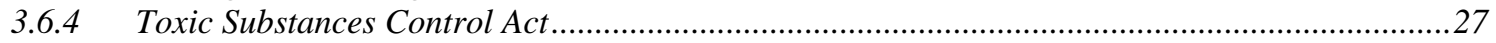

3.6.5 Federal Insecticide, Fungicide, and Rodenticide Act ...............................................................27

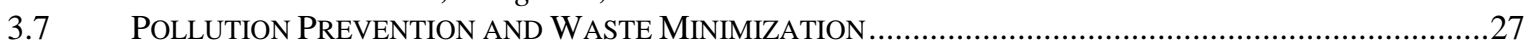

3.7.1 Pollution Prevention Requirements of DOE Order 450.1 …...............................................28

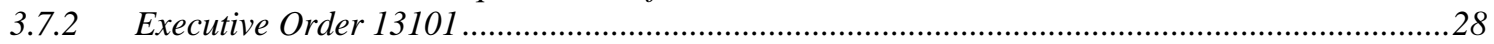

3.7.3 Hazardous Waste Source Reduction and Management Review Act ............................................29

3.7.4 Pollution Prevention Act........................................................................................................29

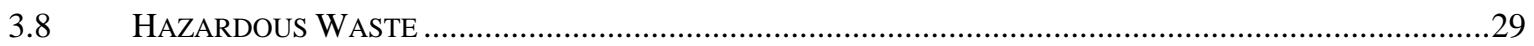

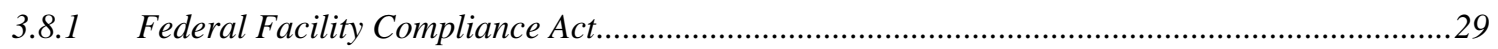

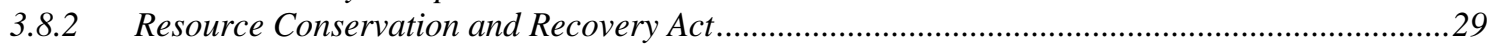

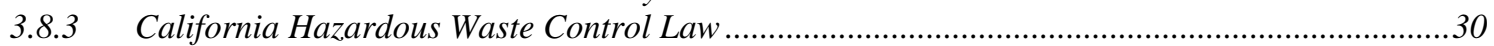

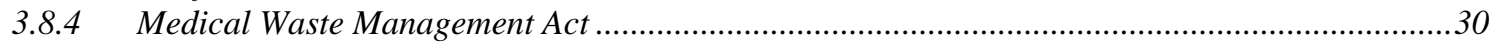

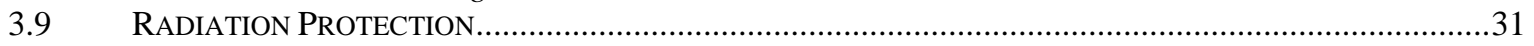

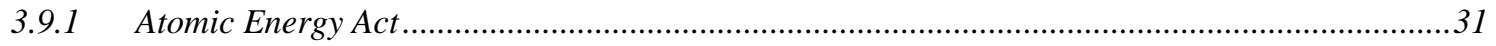

3.9.2 DOE Order 435.1, Radioactive Waste Management ....................................................................31

3.9.3 DOE Order 5400.5, Radiation Protection of the Public and the Environment .............................31 


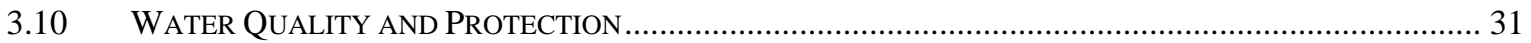

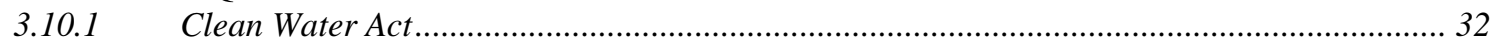

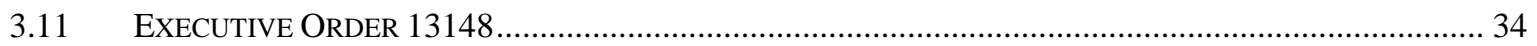

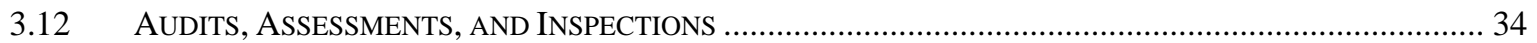

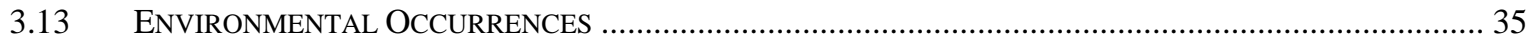

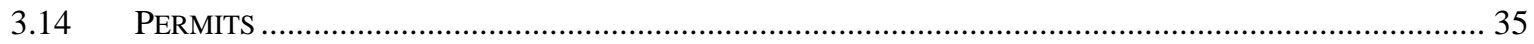

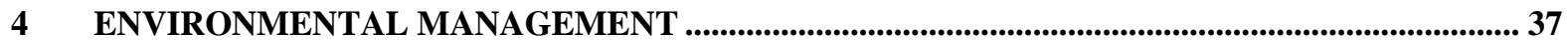

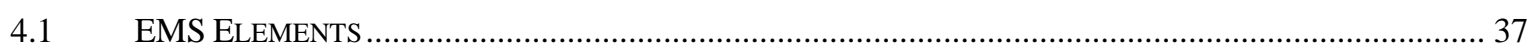

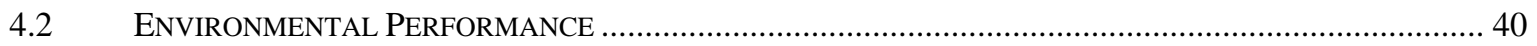

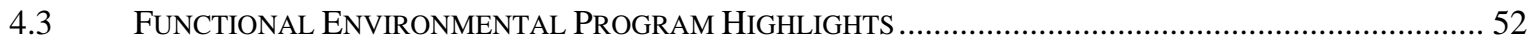

4.3.1 Air Quality Program........................................................................................................... 52

4.3.2 Environmental Monitoring and Restoration Program................................................................ 53

4.3.3 Environmental Planning and Ecology Program...................................................................... 53

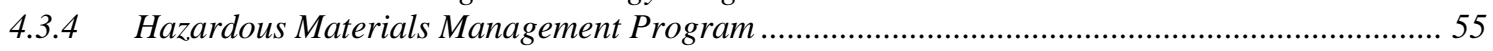

4.3.5 Pollution Prevention and Waste Minimization Program ............................................................... 55

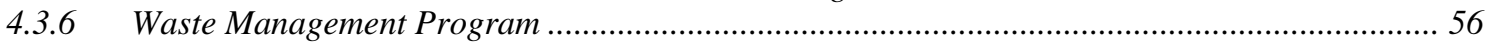

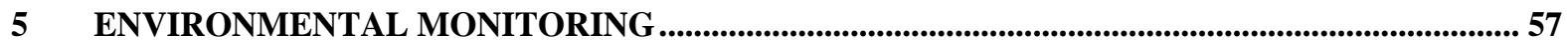

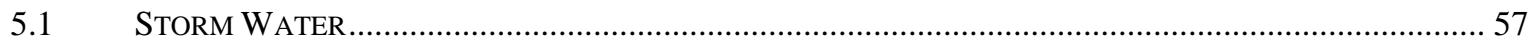

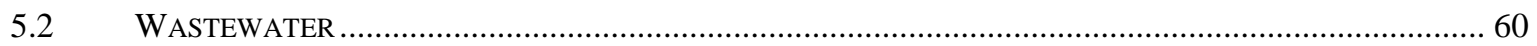

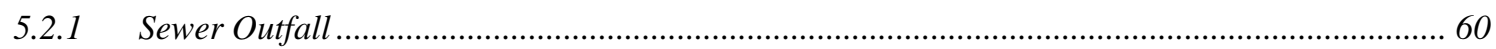

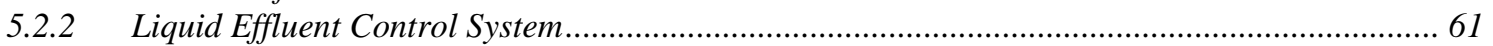

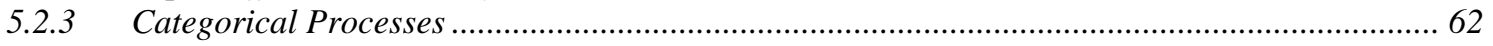

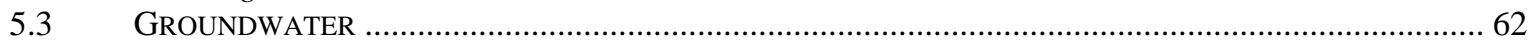

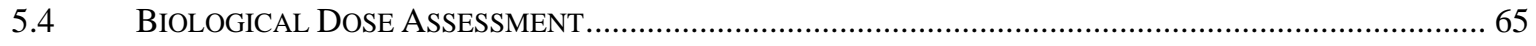

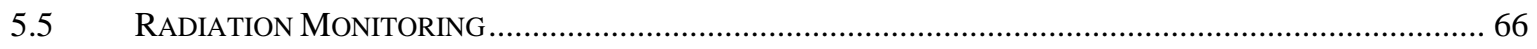

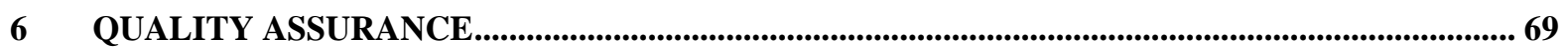

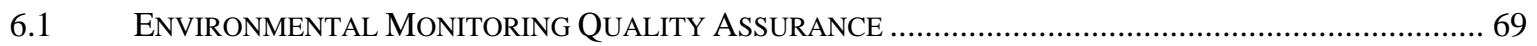

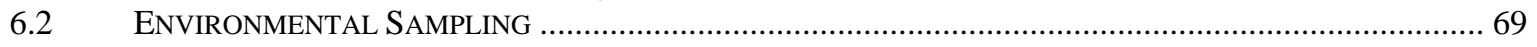

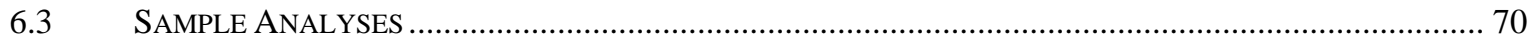

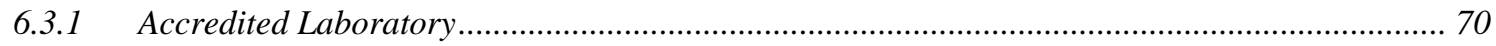

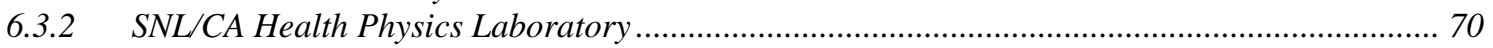

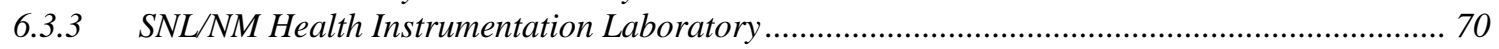

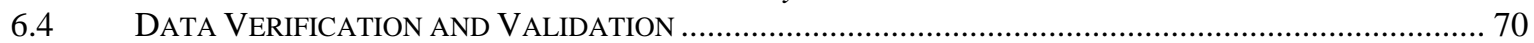

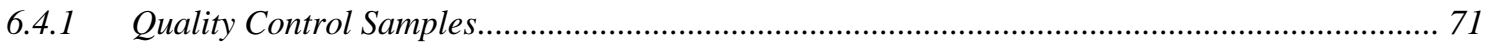

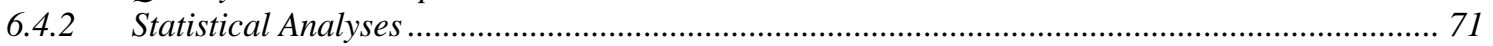

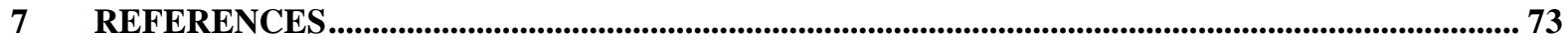

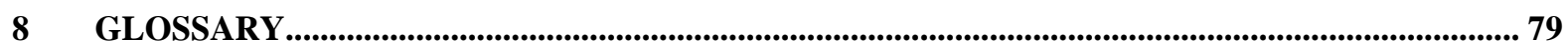

9 GROUNDWATER ANALYTICAL RESULTS AND WELL COMPLETION DATA...................... 81

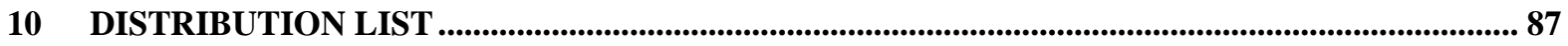

\section{Tables}

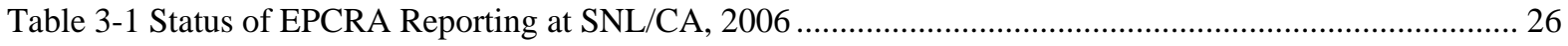

Table 3-2 Order 5400.5 Compliance Summary, 2006 ...................................................................................... 32

Table 3-3 SNL/CA Activities in Support of Executive Order 13148 ................................................................ 34

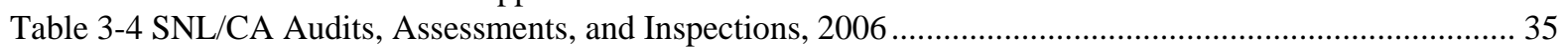

Table 3-5 SNL/CA Environmental Permits and Orders, 2006 ....................................................................... 36

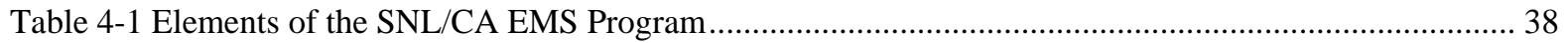

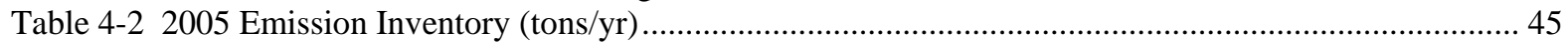

Table 4-3 Comparison of 2006 Operations with SWEA Envelope ................................................................. 54 
Table 5-1 Summary of Analytical Results for Storm Water, 2005/2006 Wet Season.......................................59

Table 5-2 Sewer Outfall Sampling Schedule, 2006..................................................................................60

Table 5-3 Weekly Composite Sewer Outfall Monitoring Results - Physical Parameters and Metals, 2006........61

Table 5-4 Monitoring for Semiconductor Manufacturing Categorical Process, 2006 .....................................62

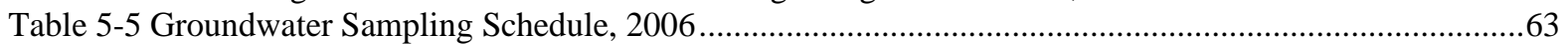

Table 5-6 Summary of Groundwater Analyses at Navy Landfill, 2006 .....................................................64

Table 5-7 Summary of Groundwater Analyses at Arroyo Seco Wells - Metals, 2006 ....................................64

Table 5-8 Summary of Groundwater Analyses at Arroyo Seco Wells - Minerals and Tritium, 2006................65

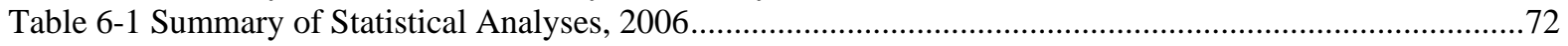

Table 9-1 Results of Quarterly Groundwater Analyses at SNL/CA, 2006 ...................................................82

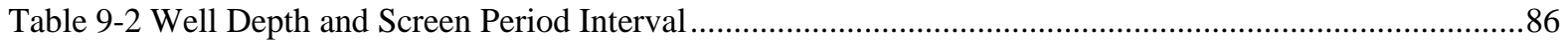

\section{Figures}

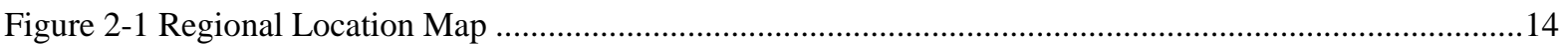

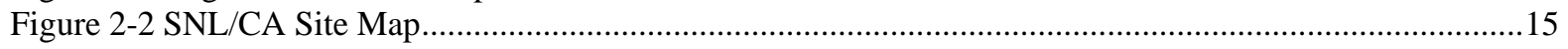

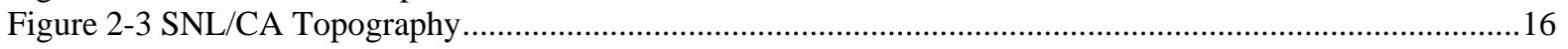

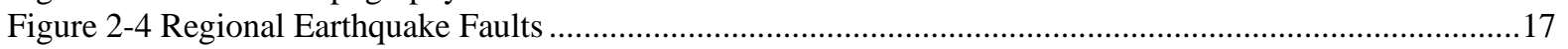

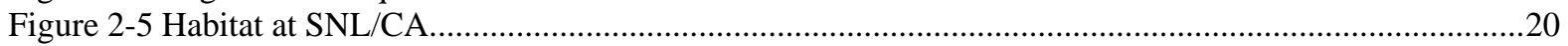

Figure 4-1 Measurement of Excellence in Environmental Management.....................................................40

Figure 4-2 Weekly Composite Copper Concentrations in Wastewater ......................................................41

Figure 4-3 Weekly Composite Zinc Concentrations in Wastewater.........................................................42

Figure 4-4 Annual Wastewater Discharges ..................................................................................42

Figure 4-5 Constituents in Storm Water, 2005/2006 Rainy Season ............................................................43

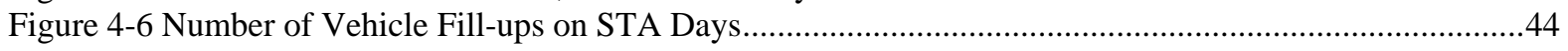

Figure 4-7 Procurement of Environmentally Friendly Products.............................................................45

Figure 4-8 Quantity and Toxicity of Hazardous Materials at SNL/CA ......................................................47

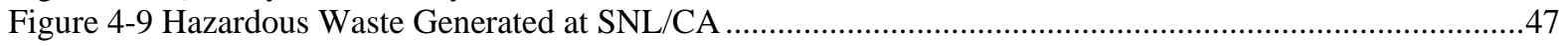

Figure 4-10 Radioactive Waste Generated at SNL/CA ...........................................................................48

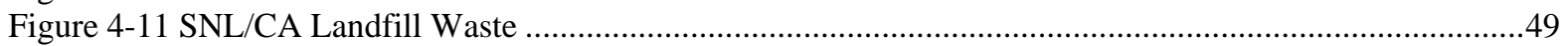

Figure 4-12 Recycled Scrap Metal, Paper, and Wood......................................................................49

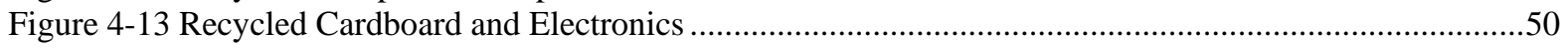

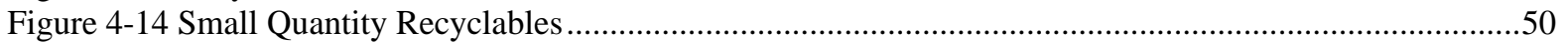

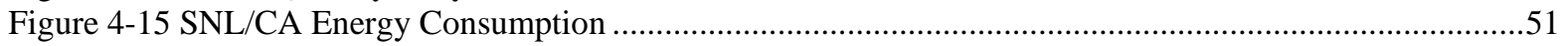

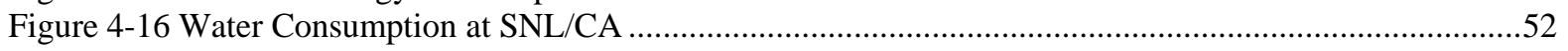

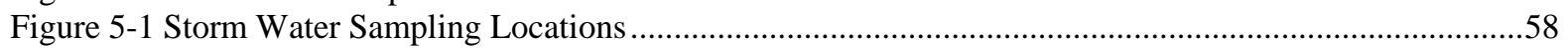

Figure 5-2 Groundwater Monitoring Well Locations ...........................................................................63

Figure 5-3 Dosimeter Locations at SNL/CA and Around Site Perimeter..................................................67

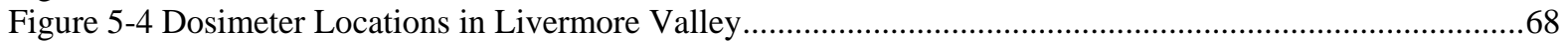




\section{Preface}

Each year, Sandia National Laboratories, California (SNL/CA) prepares a summary report to provide environmental information to the local community, pursuant to the requirements of Department of Energy Order 231.1A. The Site Environmental Report for 2006 summarizes SNL/CA's compliance with environmental requirements, presents the results of monitoring and surveillance activities, and provides an update of site environmental programs.

The Site Environmental Report for 2006 was prepared for ease in readability. Each chapter focuses on a specific topic or area. Reference to other sections and chapters is made throughout the report to avoid redundancy. Detailed data is provided only when necessary to improve the presentation of information and the quality of the document. Acronyms are defined within each chapter as well as listed at the beginning of the report. References are compiled into one list and presented at the end of the document. 


\section{Acronyms and Abbreviations}

\begin{tabular}{|c|c|}
\hline ALARA & as low as reasonably achievable \\
\hline BAAQMD & Bay Area Air Quality Management District \\
\hline BTU & British thermal unit \\
\hline CCR & California Code of Regulations \\
\hline CARB & California Air Resources Board \\
\hline CEARP & Comprehensive Environmental Assessment and Response Program \\
\hline CERCLA & Comprehensive Environmental Response, Compensation, and Liability Act \\
\hline CFR & Code of Federal Regulations \\
\hline CRMP & Cultural Resource Management Plan \\
\hline DOE & Department of Energy \\
\hline DTSC & Department of Toxic Substances Control (California) \\
\hline EMS & environmental management system \\
\hline EO & executive order \\
\hline EPA & Environmental Protection Agency \\
\hline EPCRA & Emergency Planning and Community Right-to-Know Act \\
\hline ES\&H & environment, safety, and health \\
\hline FIFRA & Federal Insecticide, Fungicide, and Rodenticide Act \\
\hline FONSI & Finding of No Significant Impact \\
\hline $\begin{array}{l}\text { General } \\
\text { Permit }\end{array}$ & $\begin{array}{l}\text { State of California, NPDES General Permit for Storm Water Discharge } \\
\text { Associated with Industrial Activities }\end{array}$ \\
\hline ISO & International Standards Organization \\
\hline $\mathrm{kg}$ & kilogram \\
\hline $\mathrm{kg} / \mathrm{yr}$ & kilogram per year \\
\hline LECS & liquid effluent control system \\
\hline LLNL & Lawrence Livermore National Laboratory \\
\hline MCLs & maximum contaminant levels \\
\hline $\mathrm{mg} / \mathrm{L}$ & milligrams per liter \\
\hline mrem & millirem \\
\hline MS4 & California Small Municipal Separate Storm Sewer System \\
\hline MSDS & material safety data sheet \\
\hline $\mathrm{mSv}$ & milliSeivert \\
\hline ND & non-detectable \\
\hline NEPA & National Environmental Policy Act \\
\hline NESHAPs & National Emission Standards for Hazardous Air Pollutants \\
\hline
\end{tabular}




\begin{tabular}{|c|c|}
\hline $\mathrm{ng} / \mathrm{L}$ & nanogram per liter \\
\hline NNSA & National Nuclear Security Administration \\
\hline NNSA/SSO & National Nuclear Security Administration, Sandia Site Office \\
\hline NPDES & national pollutant discharge elimination system \\
\hline O\&G & oil and grease \\
\hline ODS & ozone depleting substances \\
\hline PCB & polychlorinated biphenyl \\
\hline $\mathrm{pCi} / \mathrm{L}$ & picocuries per liter \\
\hline POTW & publicly owned treatment works \\
\hline $\mathrm{PP} / \mathrm{WM}$ & Pollution Prevention and Waste Minimization \\
\hline QAPP & quality assurance program plan \\
\hline RCRA & Resource Conservation and Recovery Act \\
\hline RWQCB & Regional Water Quality Control Board (California) \\
\hline $\begin{array}{l}\text { SARA } \\
\text { Title III }\end{array}$ & Superfund Amendments and Reauthorization Act of 1986, Title III \\
\hline SHPO & State Historic Preservation Officer \\
\hline SNL & Sandia National Laboratories \\
\hline $\mathrm{SNL} / \mathrm{CA}$ & Sandia National Laboratories, California \\
\hline SNL/NM & Sandia National Laboratories, New Mexico \\
\hline STA & Spare-the-Air \\
\hline SWEA & Site-wide environmental assessment \\
\hline TPHD & total petroleum hydrocarbons diesel \\
\hline TRI & toxic release inventory \\
\hline TSCA & Toxic Substances Control Act \\
\hline TSS & total suspended solids \\
\hline$\mu \mathrm{g} / \mathrm{L}$ & micrograms per liter \\
\hline U.S. & United States \\
\hline USC & United States Code \\
\hline USFWS & United States Fish and Wildlife Service \\
\hline UST & underground storage tank \\
\hline
\end{tabular}




\section{Executive Summary}

\subsection{Overview}

Sandia National Laboratories is one of three national laboratories supporting the U.S. Department of Energy (DOE) statutory responsibilities for nuclear weapon research and design, development of energy technologies, and basic scientific research. Sandia has facilities in New Mexico, California, Nevada, and Hawaii. Sandia National Laboratories, California (SNL/CA) is a multi-program engineering and science laboratory supporting the nuclear weapons stockpile program, energy and environment research, homeland security, micro- and nano-technologies, and basic science and engineering research.

The Site Environmental Report provides a summary of environmental management performance and compliance efforts at SNL/CA for calendar year 2006. The document also satisfies the DOE requirement for preparation of an annual environmental report, one of the required reports listed in DOE Order 231.1A, Environment, Safety, and Health Reporting (DOE 2004a).

The Site Environmental Report is divided into ten chapters. Chapter 1, the Executive Summary, highlights compliance and monitoring results obtained in 2006. Chapter 2 provides a brief introduction to SNL/CA and the existing environment found on site. Chapter 3 summarizes SNL/CA's compliance activities with the major environmental requirements applicable to site operations. Chapter 4 presents information on environmental management, performance measures, and environmental programs. Chapter 5 presents the results of monitoring and surveillance activities in 2006. Chapter 6 discusses quality assurance. Chapters 7 through 9 provide supporting information for the report and Chapter 10 is the report distribution list.

\subsection{Environmental Management}

Sandia maintains a comprehensive environmental management system (EMS) that incorporates environmental stewardship, compliance, and a process of continual improvement. SNL/CA's program uses the framework established by the international standard for EMS, ISO 14001. On September 25, 2006, SNL/CA obtained ISO 14001:2004 certification of its EMS. Additional information on environmental management is presented in Chapter 4.

\subsection{Performance Measures}

SNL/CA measures environmental performance as progress towards achieving EMS objectives. During 2006, SNL/CA demonstrated improvement and progress towards achieving 14 of 22 EMS objectives. Measurement data for the remaining eight objectives were not collected during 2006. SNL/CA received one notice of violation in 2006 for an administrative deficiency related to hazardous waste. Section 3.13 presents the details of this 
violation. Section 4.2 provides additional information about SNL/CA's environmental performance in 2006.

\subsection{Environmental Monitoring}

SNL/CA monitors storm water, wastewater, groundwater, and direct (ambient) radiation. The results of monitoring show that no pollutants were detected in storm water runoff at levels that are a cause for concern, and that all wastewater generated by site operations complied with the site outfall discharge limits for regulated physical parameters and metals. SNL/CA continued to see carbon tetrachloride in groundwater at the Navy Landfill in 2006 with a concentration similar to that detected in past years. Wells at the Fuel Oil Spill site had insufficient water to sample during 2006; consequently, no samples were collected. Monitoring data indicate that SNL/CA is not contributing significantly to the external radiation dose in the area. The average annual external radiation dose at the site perimeter was 62 mrem $(0.62 \mathrm{mSv})$, which is within the dose range measured over the last fifteen years. Additional information about environmental monitoring at SNL/CA is provided in Chapter 5. 


\section{Introduction}

\subsection{History and Mission}

Sandia National Laboratories, California (SNL/CA) was established in 1956 by Sandia Corporation to provide a closer relationship with Lawrence Livermore National Laboratory (LLNL) and their nuclear weapons design work. The SNL/CA facility evolved into an engineering research and development laboratory by the early 1960s, and into a multiprogram engineering and science laboratory during the 1970s. As international arms control efforts increased in the late 1970s and throughout the 1980s, the United States emphasized treaty monitoring, safety, security, and control of the national nuclear weapons stockpile. With the end of the Cold War in the late 1980s, the role of SNL/CA to support stockpile stewardship ensuring nonproliferation and continued safety, security, and reliability, took on greater importance.

\section{Research Activities at SNL/CA}

$>$ Science-based performance and reliability testing and computer-based modeling of nuclear weapon components

$>$ Development, design, and testing of nonnuclear components for nuclear weapon systems

$>$ Development and testing of materials and diagnostic equipment in support of defense programs, homeland security, and basic science and engineering

$>$ Energy and environmental research

$>$ Research and development of microelectronics, microsystems, and nanotechonolgies

SNL/CA has provided distinguished service to the nation for over 50 years through engineering support and systems integration for nuclear weapons and related national security research and development efforts. Our programs support four key areas - the national nuclear deterrence policy and stockpile security, nonproliferation and materials control, energy and critical infrastructure, and emerging threats. SNL/CA is committed to collaborative research and development with industry and universities, resulting in new and enhanced technologies that have both commercial and national security benefits.

SNL/CA is a government owned/contractor operated laboratory. The site, the buildings, and the equipment are owned by the government; while Sandia Corporation, a Lockheed Martin Company, operates the laboratory for the Department of Energy's National Nuclear Security Administration (NNSA). The NNSA/Sandia Site Office (NNSA/SSO) oversees the operations at the site, using Sandia Corporation as a management and operating contractor.

\subsection{Location}

SNL/CA is located approximately 40 miles east of San Francisco, near the City of Livermore in eastern Alameda County. The site lies at the western base of the Altamont Hills on relatively flat terrain with low relief sloping gently northwest and north. Figure 2-1 shows the regional location of the site. 
SNL/CA occupies 410 acres. The main campus (134 acres) is surrounded by the remaining undeveloped SNL/CA land (276 acres) on the east, south, and west (Figure 2-2, Site Map). To the north of SNL/CA are East Avenue and LLNL. Land use to the east and south of the site is agricultural and low-density residential. A new residential development is located along the western boundary of the site.

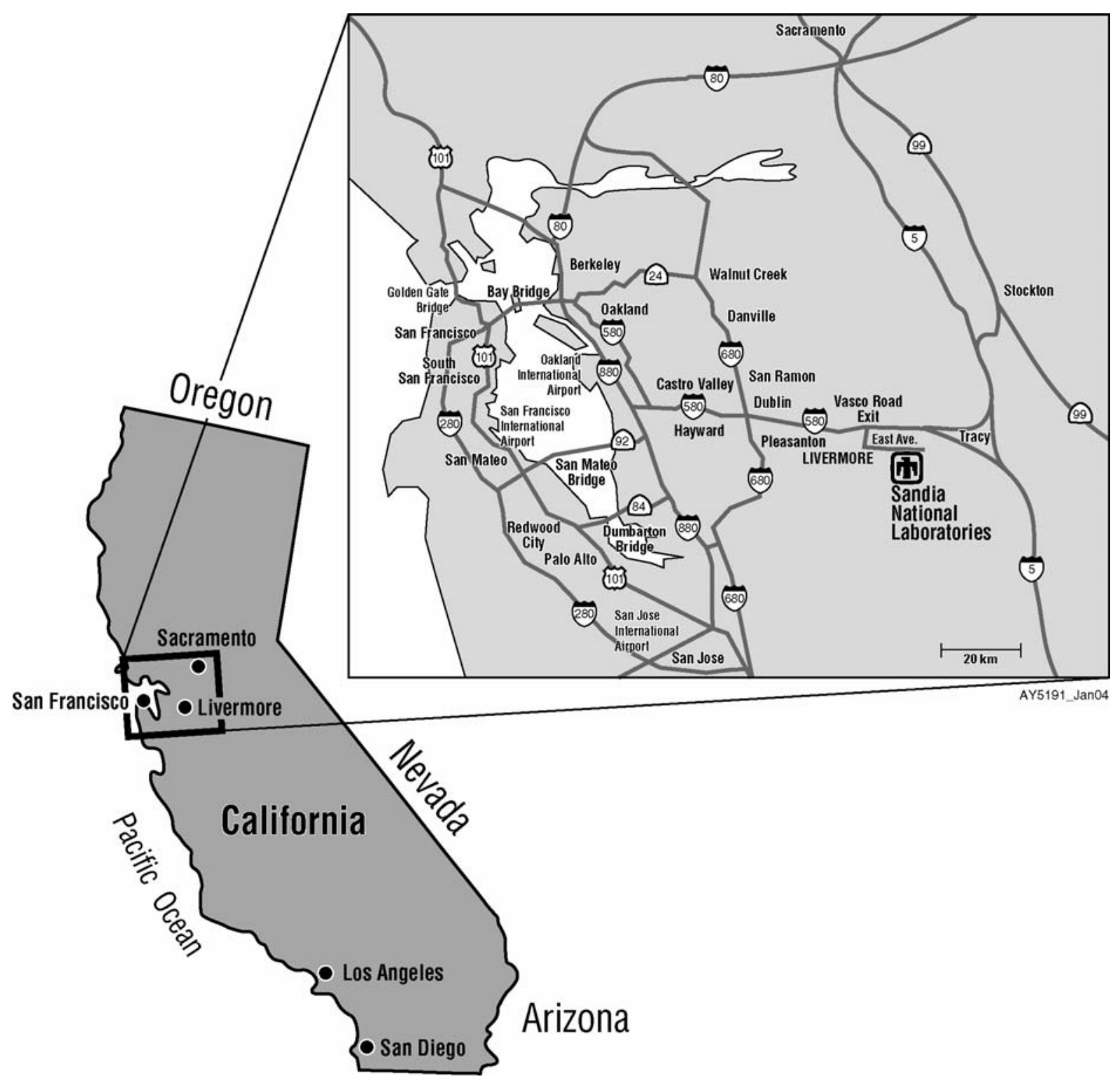

Figure 2-1 Regional Location Map 


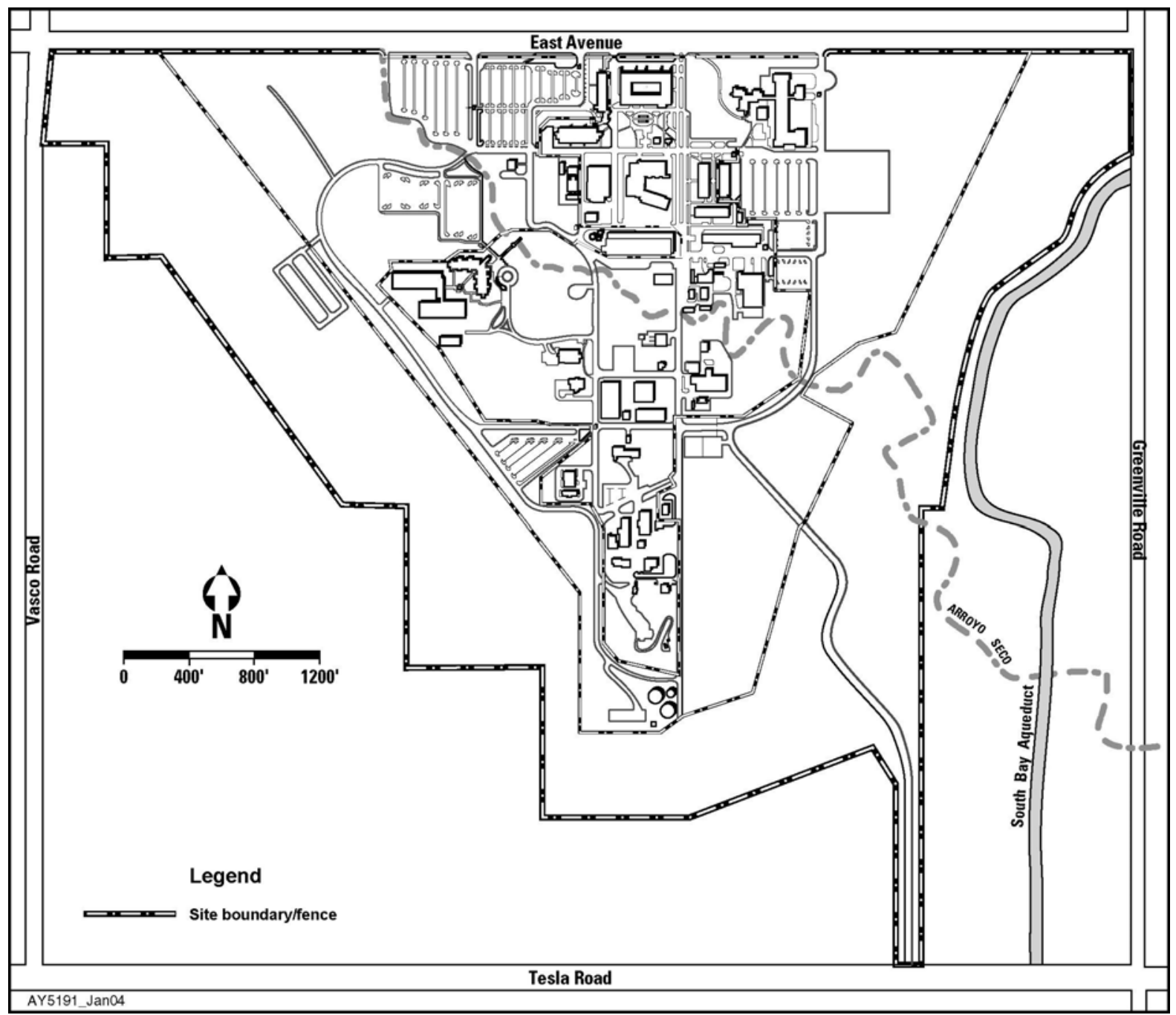

Figure 2-2 SNL/CA Site Map

\subsection{Site Population}

The SNL/CA workforce is comprised of Sandia employees (full and part-time staff, student interns, and post-doctoral appointees) and contracted staff. In September 2006, there were 1040 Sandia employees working at SNL/CA, a decrease of sixty from 2005. Eighty-two percent of Sandia employees live in Alameda, Contra Costa, and San Joaquin counties. Thirty-five percent live in Livermore. The contracted workforce fluctuates throughout the year depending on program staffing needs. An estimate of contracted staff is not available.

\subsection{Environmental Setting}

The following summarizes the environmental setting at SNL/CA. Additional information can be found in the Final Site-wide Environmental Assessment of the Sandia National Laboratories/California (DOE 2003a). 


\subsubsection{Geology and Soils}

SNL/CA is located in the California Coast Ranges geologic province in the southeastern portion of the Livermore Valley. The valley forms an irregularly shaped lowland area about 16 miles long, east to west, and 7 to 10 miles wide, north to south. The land at SNL/CA slopes gently to the northwest and north, with steep terrain in the southern portion of the site and along the banks of Arroyo Seco. The site ranges in elevation from 615 feet above mean sea level at the northwest corner of the property to 849 feet at the southern end. Site topography is depicted on Figure 2-3.

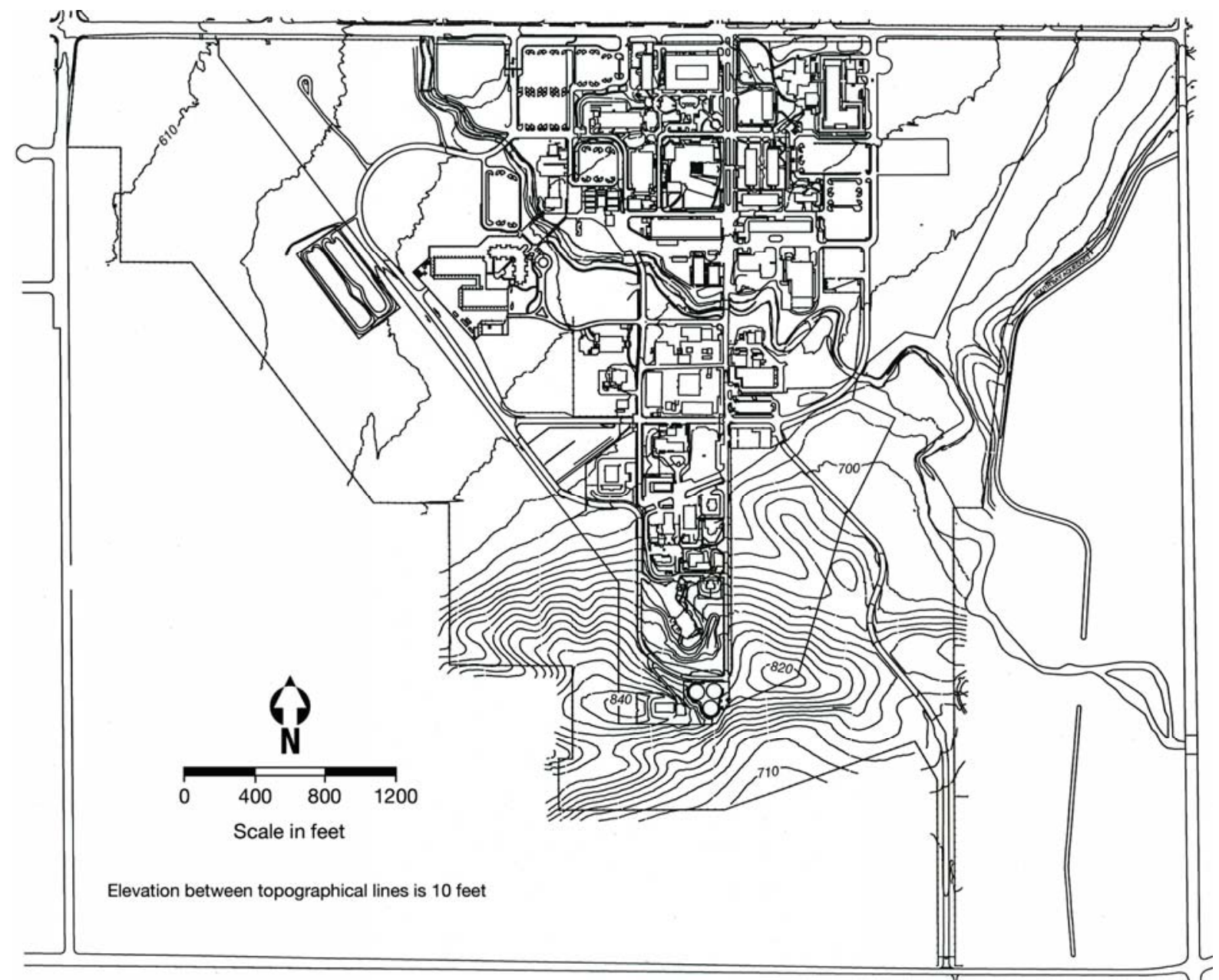

Figure 2-3 SNL/CA Topography

SNL/CA is located in a seismically active region. The major fault systems in the area are the San Andreas Fault system and the much older Coast Range thrust fault system. The upper plate of the Coast Range thrust formed the northwest trending Coast Range, including the Altamont Hills. Any seismic activity in the Livermore Valley would probably result from movement on the San Andreas Fault, a right-lateral strike-slip fault system trending northwest-southeast, extending from Point Arena to the Gulf of California. The regional faults closest to SNL/CA, the Hayward, Calaveras, Greenville, and Tesla faults follow this trend, and have been seismically active in the historic past. A magnitude 5.8 earthquake on 
the Greenville fault in 1980 caused minor damage at SNL/CA and in the Livermore Valley. The Las Positas fault crossing SNL/CA is a transverse fault, at right angles to the Greenville fault, and was active during this earthquake. The Verona fault is a low angle thrust fault, dissimilar to the regional faulting, and probably not connecting with either the Calaveras or Las Positas faults. Only microseismicity was recorded on the Verona fault in 1980. These faults are shown on Figure 2-4.

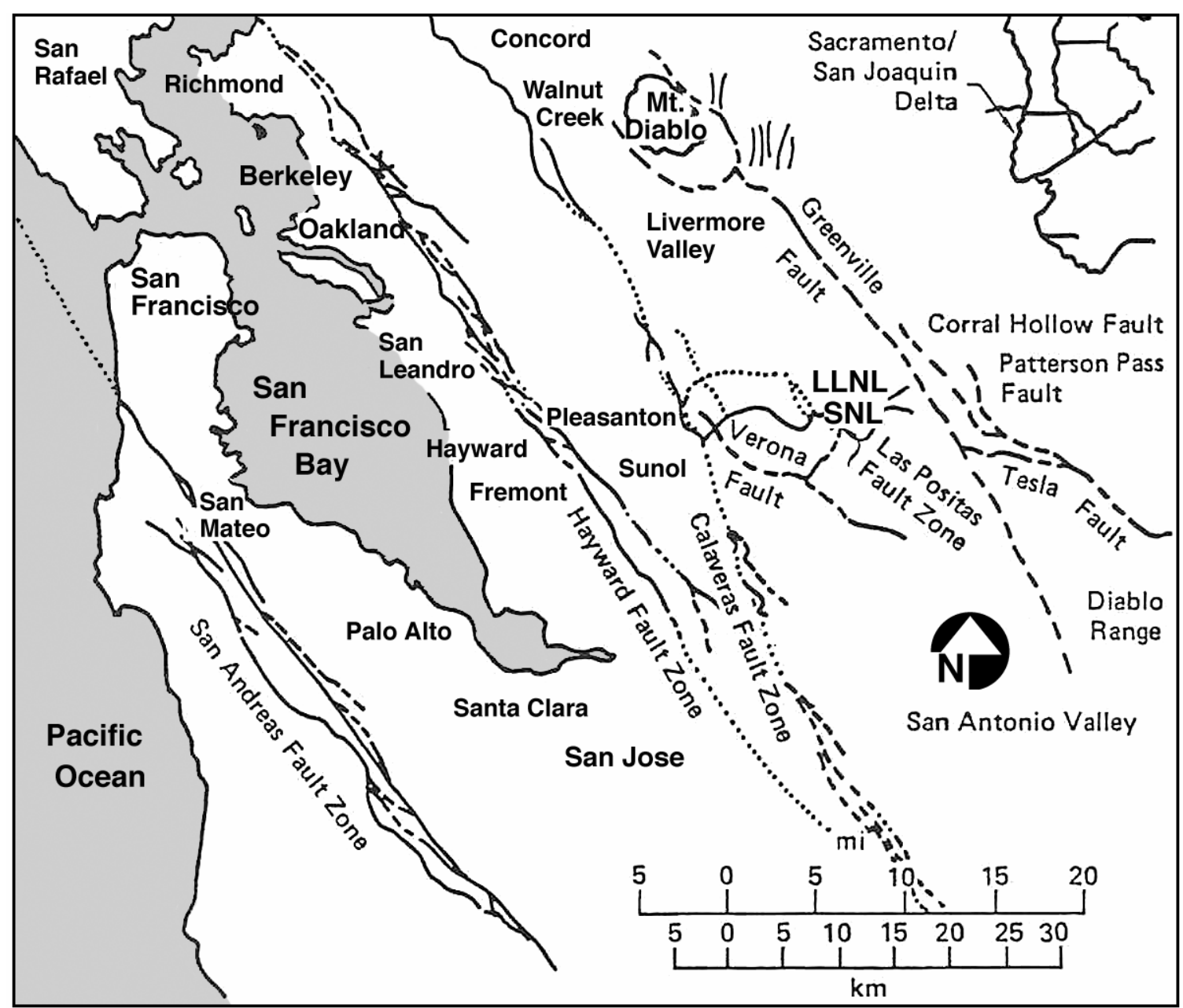

Figure 2-4 Regional Earthquake Faults

Surface soils and arroyo sediments cover the SNL/CA site. Underlying soils at the site are formed primarily upon sediments deposited by local streams. Three soils cover most of SNL/CA: Rincon clay loam, Positas gravelly loam, and Livermore gravelly loam. There are no known mineral resources or fossil occurrences at the site.

\subsubsection{Hydrology and Water Resources}

Groundwater in the SNL/CA area occurs within saturated unconsolidated geologic material. Depth to groundwater varies from less than 20 feet on the eastern portion of the site to 126 feet on the west side of the site. Water bearing-units beneath the site are composed of shallow heterogeneous, unconsolidated alluvium and deep fluvial and lacustrine sediments. 
Groundwater near SNL/CA is generally suitable for use as domestic, municipal, agricultural, and industrial supply. However, some shallower groundwater may be of marginal quality and not suitable for industrial or agricultural purposes. Groundwater less than 300 feet deep is usually unsuitable for domestic use without treatment.

SNL/CA purchases potable water from LLNL, who is supplied by the San Francisco Water District through the Hetch Hetchy Aqueduct. Additionally, the Alameda County Flood Control and Water Conservation District, Zone 7, supplements this primary water source as needed. SNL/CA's water use is metered by LLNL as it enters the site. In 2006, SNL/CA used 70.7 million gallons of water, an increase of approximately 16.1 million gallons from water used in 2005. (See discussion in Section 4.2). The site discharged approximately 11.2 million gallons of wastewater during the year. Water loss, or the difference between water use and wastewater discharge, is attributed to irrigation, cooling towers, water tank releases, evaporative losses, eyewash and safety shower testing, fire system testing, and waste water from liquid effluent control system (LECS) tanks that is trucked offsite for disposal. During 2006, one LECS tank (approximately 2100 gallons) of wastewater containing diesel constituents was transported offsite for disposal. Additional information is provided in Section 5.2.2.

There are no perennial streams or natural surface water bodies at SNL/CA. The Arroyo Seco, an ephemeral and intermittent stream, diagonally traverses the site from southeast to northwest. The arroyo typically flows only in very wet years, and for short periods of time during heavy storms. A seasonal wetland that is wet well into June, and sometimes July, is located in the streambed along the eastern part of the arroyo. Storm water runoff at SNL/CA is conveyed to Arroyo Seco through a system of storm drains and channels. The Arroyo Seco and seasonal wetland are shown on Figure 2-5.

A man-made recharge basin consisting of two cells encompassing approximately 2.7 acres, is located in the west outer perimeter area at SNL/CA. LLNL constructed the basin in 1989 to serve as a recharge basin for their groundwater treatment program. Between 1989 and 2003, treated water from the LLNL site was routinely discharged to the recharge basin cells. LLNL's groundwater restoration program has progressed to a point where recharge through the basin is no longer necessary or desirable. Consequently, in June 2005, LLNL terminated its agreement with SNL/CA for use of this area. SNL/CA plans to return the area to pre-1989 condition by backfilling and reseeding with appropriate vegetation.

\subsubsection{Climate and Meteorology}

The climate at SNL/CA is typical of the Mediterranean conditions in the San Francisco Bay region where cool, wet winters and hot, dry summers are normal. In the summer, inland valleys, such as the Livermore Valley, generally experience more sunshine and higher temperatures than the coastal areas. In the winter, temperatures in the valley are usually cooler than at the coast.

Annual meteorological data for 2006 was obtained from SNL/CA's meteorological tower. The annual rainfall for 2006 was 14.84 inches. Temperatures in 2006 ranged from $31^{\circ}$ to $109^{\circ}$ Fahrenheit. Average annual rainfall in the Livermore area over the last five years was 
13.1 inches (LLNL 2006). The windiest months in the area occur in the spring and summer, and are dominated by westerly sea breezes. The winds during the fall and winter are typically lighter and more varied in direction.

\subsubsection{Ecology}

The plant community at SNL/CA is typical of the surrounding region, consisting primarily of grassland. Localized areas of coyote brush scrub, willow riparian woodland, and wetland habitat are also present. Areas developed and disturbed by Sandia operations constitute an additional habitat type, designated altered habitat. Habitat types are depicted on Figure 2-5. No threatened, endangered, proposed, or candidate plant species are present onsite.

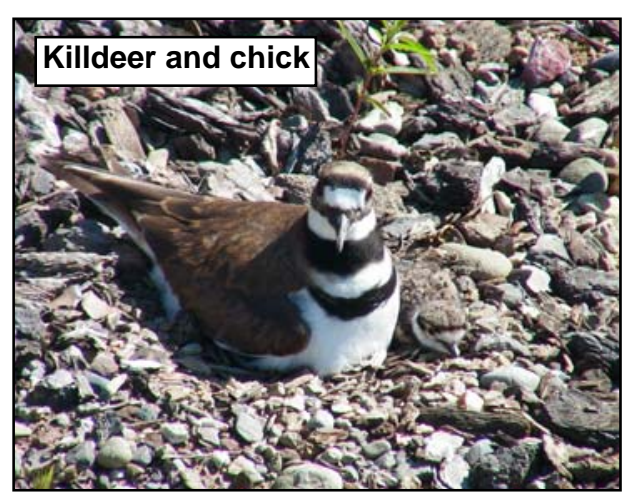

A variety of wildlife species live and forage at SNL/CA. During 2006, SNL/CA identified 67 bird species, 8 species of amphibians and reptiles, and 18 mammal species on site. SNL/CA is located within the range of the mountain lion (Puma concolor), a "specially protected mammal” under California law. Several sightings of a mountain lion were reported at SNL/CA in 2006. Passive monitoring at the site for visiting mountain lions is ongoing.

SNL/CA provides habitat (or potential habitat) for two threatened wildlife species, the California red-legged frog (Rana aurora draytonii) and the California tiger salamander (Ambystoma californiense). The most recent confirmed observation of a tiger salamander at SNL/CA was on January 6, 2003, when one salamander was found in a shallow depression filled with leaf litter. The first confirmed observation of California red-legged frogs at SNL/CA occurred in April 2004 when several individuals were seen on the eastern portion of the site in shallow water contained within Arroyo Seco. California red-legged frogs were also observed during 2005 and 2006 in this location.

Numerous bird species nest or forage on site, most of which are protected under the Migratory Bird Treaty Act. One species, the Swainson's hawk (Buteo swainsoni) observed as a fly-over at SNL/CA in April 2006, is a California state threatened species. Several birds are also special concern species. The Cooper's hawk (Accipiter cooperii), Ferruginous hawk (Buteo regalis), Northern harrier (Circus cyaneus), Sharp-shinned hawk (Accipiter striatus), and Yellow warbler (Dendroica petechia) are California species of special concern. The White-tailed kite (Elanus leucurus) and the Golden eagle (Aquila chrysaetos) are California fully protected species. The Loggerhead shrike (Lanius ludovicianus) and Western burrowing owl (Athene cunicularia) are Federal birds of conservation concern and California species of special concern. The Loggerhead shrike was the only special concern species nesting at SNL/CA in 2006.

SNL/CA maintains a wildlife website to provide information on the site's wildlife and ecology. The website was established in 2004 and includes information on site requirements, a photo gallery, summaries of survey activities, species information, and informational 
posters. The wildlife website is publicly available from the external Sandia California website at http://www.ca.sandia.gov/wildlife/.

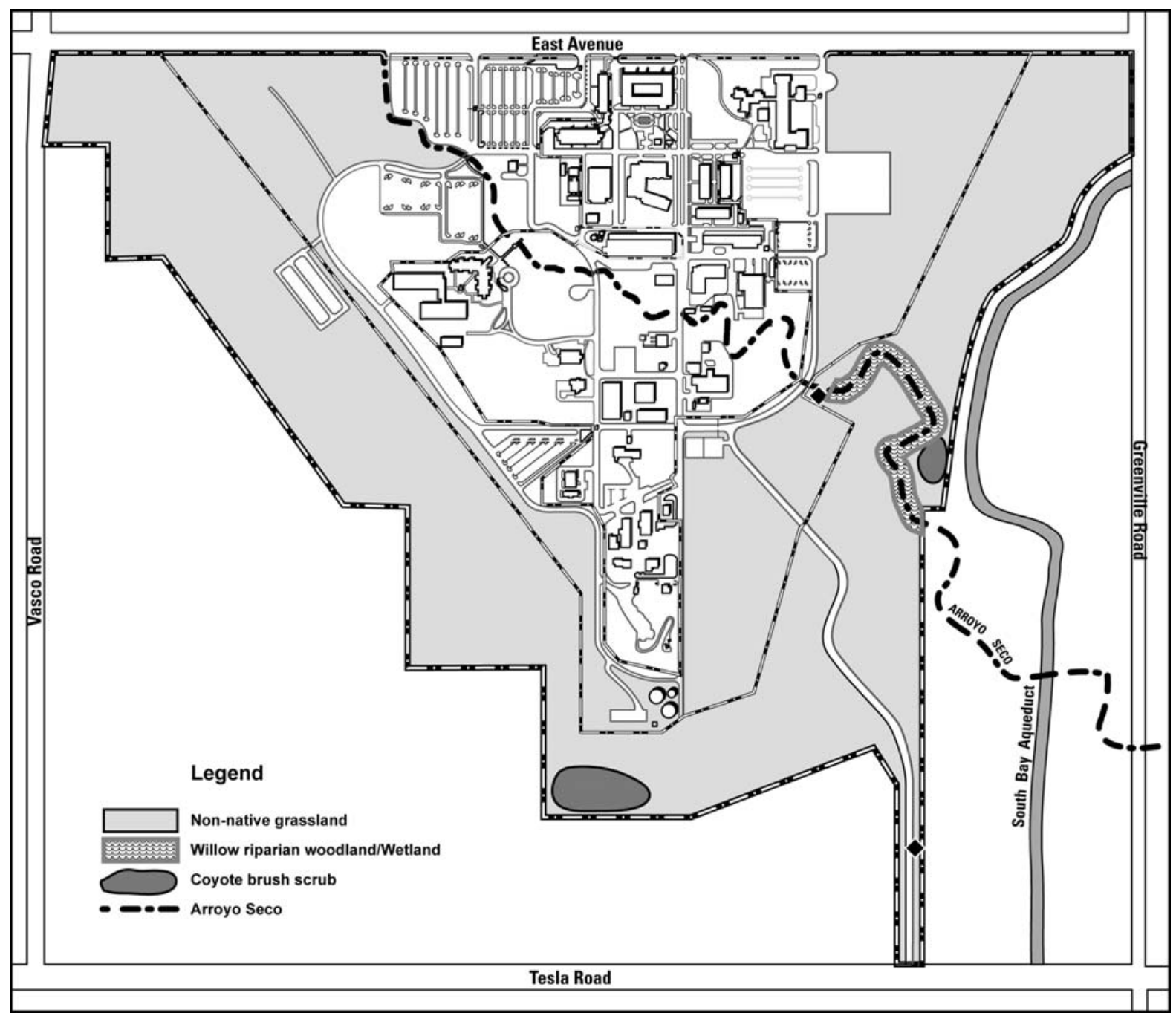

Figure 2-5 Habitat at SNL/CA 


\section{Compliance Summary}

Sandia National Laboratories, California (SNL/CA) operates in compliance with the letter and spirit of applicable federal, state, and local environmental laws and regulations. Additionally, as a Department of Energy (DOE) facility, the site is subject to DOE directives (DOE orders), and to presidential executive orders. This chapter provides a summary of SNL/CA compliance with major environmental requirements for calendar year 2006.

\subsection{DOE Order 450.1}

DOE Order 450.1, Environmental Protection Program outlines the basic strategy for environmental compliance at DOE facilities, including SNL/CA. The objectives of Order 450.1 are to implement sound environmental stewardship practices, and to meet or exceed compliance with environmental, public health, and resource protection laws, regulations, and DOE requirements (DOE 2005b). The order requires DOE sites to meet these objectives through an environmental management system (EMS) that integrates environment, safety, and health into work planning and execution. Sandia implemented its EMS in December 2005, the DOE established deadline. In 2006, SNL/CA upgraded the EMS Program to fully conform to the international standard for EMS, ISO 14001:2004, and received third-party certification to the standard. Chapter 4 provides additional information on SNL/CA's EMS program.

\subsection{National Environmental Policy Act}

The National Environmental Policy Act (NEPA) is the basic national charter for protection of the environment. It requires all federal agencies to evaluate the affects of major federal actions on the human environment, including the physical, socioeconomic, and cultural environments. NEPA review of DOE actions is conducted in accordance with DOE NEPA Implementing Procedures (10 CFR 1021). Under these procedures, DOE may prepare a programmatic (including site-wide) document at any time to further the purposes of NEPA. In 2003, DOE's National Nuclear Security Administration/Sandia Site Office (NNSA/SSO) issued a site-wide environmental assessment (SWEA) for continued operations at SNL/CA (DOE 2003a) and a Finding of No Significant Impact (FONSI) on March 20, 2003 (DOE 2003b). The SWEA evaluates the impacts of site operations over the next ten years, and the FONSI concludes that continuation of site operations is not a major federal action significantly affecting the quality of the human environment.

SNL/CA supports compliance with NEPA and DOE's NEPA Implementing Procedures by reviewing all new projects and programs or changes to existing projects and programs to ensure that they fit within the bounds of existing NEPA documents and impact analyses for the site. The SNL/CA NEPA review process is documented in an administrative procedure (SNL/CA 2005a) that is reviewed and updated every three years, or as needed. During fiscal year 2006, 130 projects underwent NEPA review. None of these projects required preparation of an environmental assessment or environmental impact statement. 


\subsection{Air Quality}

\subsubsection{Clean Air Act}

The Clean Air Act (42 USC § 7401) is the federal statute that forms the basis for the national air pollution control effort. It authorizes the Environmental Protection Agency (EPA) to promulgate air quality regulations and establishes national ambient air quality standards for criteria pollutants. Authority to implement the requirements of the Clean Air Act is provided to each state that has an EPA approved State Implementation Plan. The State Implementation Plan for California describes how National Ambient Air Quality Standards will be obtained in each air district. Each district establishes and enforces air pollution regulations to attain and maintain state and federal ambient air quality standards. The Bay Area Air Quality Management District (BAAQMD) is the regulating authority for controlling air pollution from stationary sources at SNL/CA. The California Air Resources Board (CARB) is responsible for ensuring that federal and state standards are met for mobile and small "area" sources of air pollution.

SNL/CA does not have any major sources of air pollutants (as defined in 40 CFR Part 70.2) present on site. SNL/CA works with the BAAQMD and CARB to permit or register all regulated emission sources. For the 2005/2006 permit period ${ }^{1}$, SNL/CA had 15 permitted emission sources. The number of permits remained at 15 for the 2006/2007 permit period. Table 3-5 (Section 3.14) provides a list of the permitted sources.

\subsubsection{Radionuclide Emissions}

The National Emissions Standards for Hazardous Air Pollutants, Subpart H - National Emission Standards for Emissions of Radionuclides Other Than Radon From Department of Energy Facilities (NESHAPs) (40 CFR Part 61) establishes radiation protection standards, monitoring requirements, and annual reporting of radionuclide air emissions. Additional requirements pertaining to radionuclide emissions are contained in DOE Order 450.1, Environmental Protection Program (DOE 2005b), and DOE Order 5400.5, Radiation Protection of the Public and the Environment (DOE 1993).

SNL/CA does not currently have any radionuclide emission sources that are subject to the monitoring requirements of 40 CFR Part 61. To comply with national emission standards, SNL/CA evaluates individual projects with the potential to release radionuclide emissions to determine the worst-case dose to the public. Additionally, dose calculations are compared to the requirements to determine the need for annual monitoring. During 2006, SNL/CA evaluated one project with the potential to produce radionuclides through nuclear fission in a non-sealed source. Conservative estimates based on the rate of fission indicated that the amount of radionuclides produced would be several orders of magnitude below the annual possession quantities in 40 CFR 61.

\footnotetext{
${ }^{1}$ The BAAQMD permit period is July 1 through June 30 each year. Permit data is presented for the two periods applicable to 2006.
} 


\subsection{Natural and Cultural Resources}

\subsubsection{Endangered Species Act}

The Endangered Species Act (16 USC § 1531 et. seq.) provides for protection of plant and wildlife species in danger of becoming extinct. In 2002, NNSA/SSO and SNL/CA initiated consultation with the U.S. Fish and Wildlife Service (USFWS) under Section 7 of the Endangered Species Act for maximum operations of the SNL/CA site. On December 8, 2004, the USFWS issued a biological and conference opinion for continued operations at SNL/CA. The biological opinion concludes that proposed site operations are not likely to jeopardize the continued existence of the California red-legged frog (Rana aurora draytonii) and the California tiger salamander (Ambystoma californiense), the two threatened species present on site. The conference opinion concludes that site operations are not likely to destroy or adversely modify proposed critical habitat for the red-legged frog ${ }^{2}$.

In October 2006, NNSA/SSO and SNL/CA submitted a request to the USFWS for an amendment to the December 2004 biological and conference opinion. NNSA/SSO and SNL/CA are seeking an amendment to backfill a man-made recharge basin that is no longer needed and designate the area for future construction. Because the recharge basin was still in use at the time of the initial consultation, the project was not included as part of the SNL/CA maximum operations alternative. SNL/CA and NNSA/SSO met with the USFWS on December 13, 2006 to discuss the proposed action. Because California tiger salamanders were found in the area in the past, the USFWS indicated that a mitigation offset would be required for the proposed construction zone. Project planning will continue in 2007.

\subsubsection{Interim Protections for California Red-legged Frogs}

In October 2006, interim restrictions on pesticide use went into effect to protect the California red-legged frog. The restrictions are the result of a settlement agreement between the EPA and the Center for Biological Diversity that requires the EPA to consult with the USFWS under the Endangered Species Act on the impacts of 66 pesticide ingredients to the red-legged frog. The agreement, outlined in a Stipulated Injunction and Order (US District Court 2006), places restrictions on the use of these pesticides in red-legged frog aquatic and upland habitat until consultations are complete and biological opinions are issued by the USFWS. In response to these interim protections, SNL/CA has restricted the use of products containing the named pesticide ingredients in and along Arroyo Seco.

\footnotetext{
${ }^{2}$ In 2002, when the consultation process began, the Sandia site was within designated critical habitat for the California red-legged frog. In November 2002, the designation was overturned (U.S. District Court 2002), and in April 2004, the USFWS re-issued proposed critical habitat that included the Sandia site (USFWS 2004). However, in November 2005, the USFWS issued a revised designation (USFWS 2005), and a final rule in April 2006 (USFWS 2006). Under the 2006 final designation, the Sandia site is not included in the critical habitat area.
} 


\subsubsection{Migratory Bird Treaty Act}

The Migratory Bird Treaty Act (16 USC $\$ 703$ et. seq.) provides for protection of migratory birds, their nests, and eggs. Sixty-one of the 67 bird species observed at SNL/CA in 2006 are protected under this act. In 2006, there was no intentional take of migratory birds or disturbance to nests or eggs at the site. Migratory birds often build nests within the developed campus in locations where they will be disturbed by maintenance activities. To avoid harming birds, nests, or eggs, SNL/CA delays activities until the young have fledged, or surveys determine that the nest is abandoned. In 2006, three maintenance activities were delayed to protect nesting birds.

\subsubsection{Floodplain Management}

Executive Order 11988, Floodplain Management (EO 11988), requires federal agencies to consider impacts associated with the occupancy and modification of floodplains, to reduce the risk of flood loss, to minimize the impact of floods on human safety, health, and welfare, and to restore and preserve the natural and beneficial values served by floodplains. In 2002, SNL/CA completed a management plan for the Arroyo Seco to identify channel improvements and stream zone management activities that will reduce flood and erosion risk

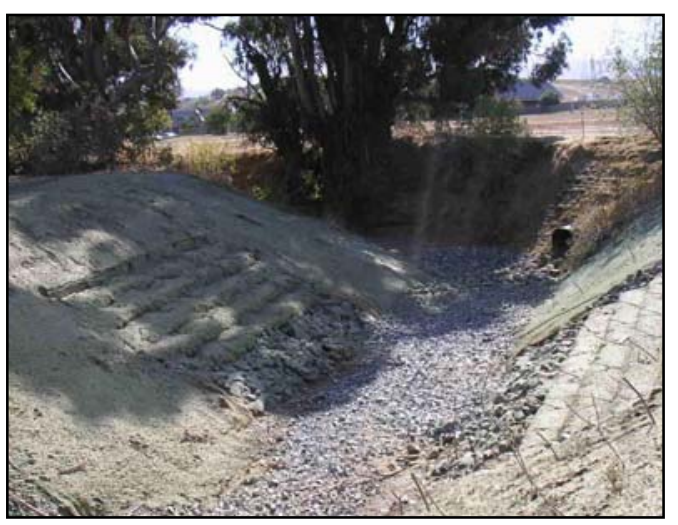
and provide improved habitat for wildlife species that may use the arroyo (Matthews 2002). The plan identifies areas for constructing functional floodplains and for planting of native riparian vegetation. During 2005, the U.S. Army Corp of Engineers authorized five tasks identified in the Arroyo Seco management plan. SNL/CA completed these five tasks during 2006. Also in 2006, SNL/CA submitted design packages for the fifteen remaining arroyo improvements outlined in the management plan. Approval from the Army Corp is pending.

\subsubsection{Protection of Wetlands}

Executive Order 11990, Protection of Wetlands (EO 11990), requires federal agencies to minimize the destruction, loss, or degradation of wetlands and preserve and enhance the natural and beneficial values of wetlands. A small wetland area of 0.44 acres is present at SNL/CA. During 2006, SNL/CA did not conduct any activities in the wetland area, or affecting wetlands.

\subsubsection{National Historic Preservation Act}

The National Historic Preservation Act (16 USC § 470) requires federal agencies to identify, record, and protect cultural resources. In 1990, an assessment of cultural resources at the SNL/CA site was completed. Although no prehistoric resources, Native American resources, or historic archaeological sites were identified during this assessment, there is a possibility that buried resources could be present on site (DOE 2003a). SNL/CA includes provisions for 
cultural resources in all construction-related contracts where the potential for buried resources may be unearthed. In 2006, there were no buried archaeological resources unearthed at SNL/CA.

In 2001, SNL/CA completed an historic building survey. None of the buildings onsite are identified as historically significant or eligible for the National Register of Historic Places (SNL 2002). The results of the historic building survey were submitted to NNSA/SSO. In December 2004, NNSA transmitted the survey results to the California State Historic Preservation Officer (SHPO). In April 2005, NNSA/SSO received concurrence from the California SHPO that none of the properties located at SNL/CA are eligible for inclusion in the National Register of Historic Places.

On September 22, 2004, DOE issued updated guidelines for developing cultural resource management plans (CRMP) for all DOE facilities (DOE 2004b). These guidelines are intended to assist each facility in meeting the statutory and regulatory requirements applicable to cultural resources. In 2005, SNL/CA prepared a site-specific CRMP following DOE guidance.

\subsection{Environmental Restoration}

\subsubsection{Comprehensive Environmental Response, Compensation, and Liability Act}

Between 1984 and 1986, DOE investigated the SNL/CA site under their Comprehensive Environmental Assessment and Response Program (CEARP) to identify and assess potential environmental problems (DOE 1986). The CEARP investigation evaluated compliance with major federal environmental laws, including the Comprehensive Environmental Response, Compensation, and Liability Act (CERCLA) (42 USC § 9601). CERCLA established liability compensation, cleanup, and emergency response for hazardous substances released to the environment. During the CEARP investigation, two potential CERCLA sites were identified at SNL/CA, the Fuel Oil Spill Site and the Navy Landfill. A Hazard Ranking System study was performed for each site to determine if either qualified for listing on the National Priorities List. Hazard Ranking System scores for both sites fell below 28.5, the qualifying score for listing. Since completion of the CEARP investigation, there have been no hazardous substance releases or contaminated sites found at SNL/CA that warranted CERCLA investigation or a Hazard Ranking System study.

In addition to cleanup and emergency response requirements, CERCLA also established a program to report spills of hazardous substances to the National Response Center. SNL/CA incorporates CERCLA reporting requirements into an operating procedure for spill prevention and control (SNL/CA 2004a). In 2006, there were no releases of hazardous substances that required notification under CERCLA.

\subsubsection{Site Clean-up Orders}

Since 1985, environmental restoration and monitoring activities at SNL/CA have been conducted in compliance with site clean-up orders issued by the California Regional Water 
Quality Control Board, San Francisco Bay Region under provisions established in the California Water Code (California RWQCB 1989). Although there are no active remediation sites at SNL/CA, groundwater monitoring is ongoing at two locations, the Fuel Oil Spill site and the Navy Landfill. SNL/CA currently samples three groundwater monitoring wells for residual contamination: two at the Fuel Oil Spill site (when there is sufficient water to collect a sample); and one at the Navy Landfill. Sampling results are presented in Chapter 5, Environmental Monitoring.

\subsection{Hazardous Materials}

\subsubsection{Emergency Planning and Community Right-to-Know Act}

The Emergency Planning and Community Right-to-Know Act (EPCRA) -- also known as the Superfund Amendments and Reauthorization Act of 1986, Title III (SARA Title III) (42 USC $\S 11001$, et. seq.) -- requires reporting of toxic chemical usage and releases. To meet EPCRA requirements, SNL/CA submits annual reports to the EPA, the State of California, Alameda County Department of Environmental Health, and the LLNL Fire Department, which serves as the local fire department. EPCRA reporting requirements applicable to SNL/CA for 2006 are presented in Table 3-1.

Table 3-1 Status of EPCRA Reporting at SNL/CA, 2006

\begin{tabular}{llc}
\hline EPCRA Section & Description of Reporting & Required in 2006 \\
\hline Sec. 302-303 & Planning Notification & $\begin{array}{c}\text { Yes } \\
\text { (sulfuric acid only) }\end{array}$ \\
\hline Sec. 304 & Extremely Hazardous Substances Release Notification & No \\
\hline Sec. 311-312 & Material Safety Data Sheet/ Chemical Inventory & Yes \\
\hline Sec. 313 & Toxic Release Inventory Reporting & Yes (lead only) \\
\hline
\end{tabular}

\subsubsection{California Hazardous Materials Release Response Plans and Inventory Law}

The California Hazardous Materials Release Response Plans and Inventory Law (Assembly Bill 2185) addresses the management of hazardous and acutely hazardous materials in the state. Additional requirements pertaining to hazardous materials are codified in the California Health and Safety Code, Division 20, Chapter 6.95 §25500, et seq. In compliance with California requirements, SNL/CA annually submits a Hazardous Material Business Plan to the Alameda County Department of Environmental Health.

\subsubsection{Underground Storage Tanks}

Hazardous or petroleum products stored in underground storage tanks (UST) are regulated under California Health and Safety Code Division 20, Chapter 6.7, §§ 25280-25299.8. California code incorporates the UST provisions of the Resource Conservation and Recovery Act (RCRA) and establishes standards for construction, operation, maintenance, inspection, and testing of USTs. Alameda County Environmental Health Department is the regulating authority for USTs at SNL/CA. SNL/CA operates one UST in accordance with California 
requirements. Each year, SNL/CA declares and permits the tank with the Alameda County Office of Environmental Health. This declaration is part of the Hazardous Material Business Plan described in Section 3.6.2.

\subsubsection{Toxic Substances Control Act}

The Toxic Substances Control Act (TSCA) is the primary Federal statute regulating the manufacture, use, distribution, disposal, import, or export of certain chemicals and substances (15 USC § 2601 et. seq.). TSCA requirements that are applicable to Sandia operations are incorporated into the Sandia ES\&H Manual (SNL 2006b). For SNL/CA operations, the only TSCA regulated chemicals imported or exported are for research and development purposes thus exempt from reporting to EPA. In 2006, SNL/CA was not required to prepare any TSCA declarations for submittal to EPA.

SNL/CA tracks disposal of TSCA materials that are not otherwise captured as RCRA or California toxic hazardous waste. These materials include asbestos and polychlorinated biphenyls (PCBs). The majority of TSCA waste generated onsite is asbestos from abatement activities. Only small quantities of PCB wastes are generated at SNL/CA, consisting of light ballasts that are not specifically marked as PCB-free.

\subsubsection{Federal Insecticide, Fungicide, and Rodenticide Act}

The Federal Insecticide, Fungicide, and Rodenticide Act (FIFRA) restricts the registration, sale, use, and disposal of pesticides (includes herbicides, insecticides, fungicides, and rodenticides) (7 USC $\S 136$ ). Activities at SNL/CA that fall under the provisions of FIFRA include the storage and use of pesticides, and disposal of pesticide containers. Pesticide handling and storage follows a site-specific standard operating procedure that includes provisions for training, use of personal protective equipment, proper handling following manufacturers guidelines, secondary containment during storage, and disposal of product and containers (SNL/CA 2004b). Pesticide use at SNL/CA is overseen by a certified pesticide applicator.

\subsection{Pollution Prevention and Waste Minimization}

Pollution prevention concepts first appeared in RCRA. An expressed concern was to minimize the generation of hazardous waste through process substitution, materials recovery, recycling, reuse, and treatment. RCRA established the reduction or elimination of hazardous waste as national policy, and required that hazardous waste generators and RCRA permit holders have a program in place to minimize waste. SNL/CA is required to report waste generation and recycling information yearly to DOE. To meet this requirement, the Annual Waste Generation and Pollution Prevention Progress Report was submitted to DOE on November 30, 2006 (SNL/CA 2006c). Additionally, SNL/CA's Waste Minimization Certificate required by the Hazardous Waste Storage Facility Part B Permit was submitted to the California Department of Toxic Substances Control (DTSC) prior to the March deadline. 


\subsubsection{Pollution Prevention Requirements of DOE Order $\mathbf{4 5 0 . 1}$}

On December 7, 2005, DOE issued changes to DOE Order 450.1 that establish five performance-based pollution prevention and sustainable environmental stewardship goals. These goals supersede the pollution prevention leadership goals that expired in 2005. During 2006, SNL/CA developed and implemented site-specific activities to support the new DOE goals including:

$>$ improvements to the Green Purchasing Team;

$>$ recycling of additional waste streams; and

$>$ evaluation of the site-wide recycling program for improvement opportunities.

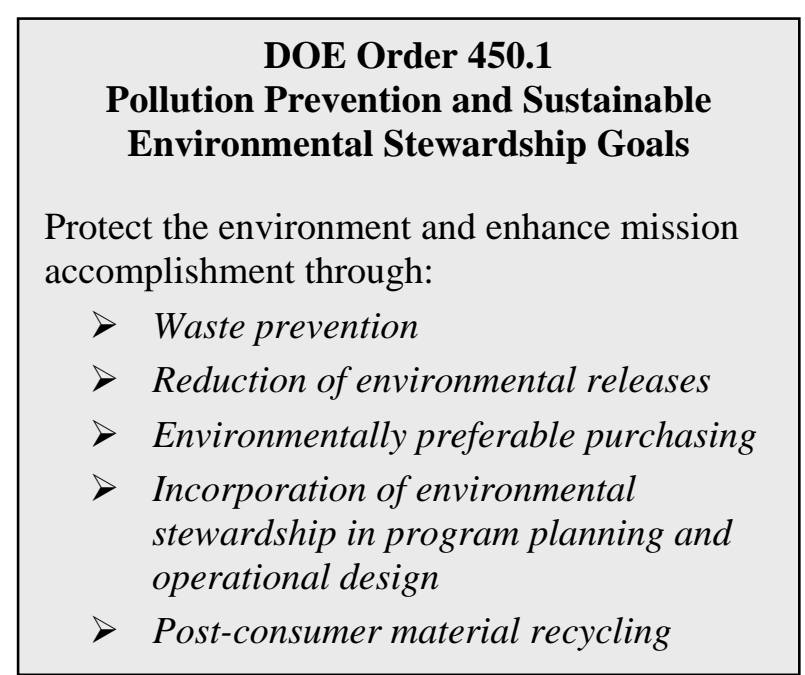

Additional information about each of these activities is provided in Chapter 4.

\subsubsection{Executive Order 13101}

Executive Order 13101, Greening the Government Through Waste Prevention, Recycling, and Federal Acquisition (EO 13101) ( $^{3}$ directs executive agencies to implement affirmative procurement programs that favor acquisition and use of recycled products and environmentally preferable products and services. EO 13101 also establishes an annual reporting requirement for federal agencies.

At SNL/CA, affirmative procurement is a coordinated effort between the Pollution Prevention and Waste Minimization (PP/WM) Program and the Procurement Department. The PP/WM staff communicates the requirements of EO 13101 through presentations and training targeting individuals involved in purchasing products and services. Both groups work closely with suppliers to ensure that environmentally preferable products are available for purchase.

The performance-based pollution prevention and sustainable environmental stewardship goal established in Order 450.1 for environmentally preferable purchasing supersedes the goal established by DOE in 1996. In 2006, 86.7 percent of the products purchased by SNL/CA met EPA standards for justified and recycled content, compared to 84.6 percent in 2005. SNL/CA electronically submitted this affirmative procurement information to DOE on November 30, 2006 for use in the annual DOE environmentally preferable products report.

\footnotetext{
${ }^{3}$ On January 24, 2007, EO 13423 was issued. This new executive order revokes and consolidates five executive orders, including EO 13101.
} 


\subsubsection{Hazardous Waste Source Reduction and Management Review Act}

The California Hazardous Waste Source Reduction and Management Review Act of 1989, (Senate Bill 14), requires hazardous waste generators to consider source reduction as the preferred method of managing hazardous waste. Under this act, facilities that generate more than 12,000 kilograms (kg) of hazardous waste or $12 \mathrm{~kg}$ of extremely hazardous waste annually are required to conduct source reduction planning.

Under an agreement between DOE and DTSC, all of DOE's California sites are considered one waste generator, rather than individual DOE facilities. Every four years, SNL/CA completes a Source Reduction and Evaluation Review and Plan in cooperation with the three other DOE sites in California: Lawrence Livermore National Laboratory (LLNL); Lawrence Berkeley National Laboratory; and Stanford Linear Accelerator Center. The most recent plan was completed in August 2003 and provides information for 1999 through 2002. The plan also identifies waste reduction opportunities for any waste stream that is over 5 percent of a site's total routine regulated waste. The next plan, which will include information from calendar year 2006, will be prepared in 2007.

\subsubsection{Pollution Prevention Act}

The Pollution Prevention Act of 1990 declares, as national policy, that pollution should be prevented or reduced at the source (42 USC $\S 13101$ et. seq.). Facilities that meet the reporting requirements under EPCRA, Section 313 are also required to file a toxic chemical source reduction and recycling report. The Section 313 report for 2006 will include source reduction and recycling information to meet this requirement. See Section 3.6.1 for additional information on EPCRA reporting requirements.

\subsection{Hazardous Waste}

\subsubsection{Federal Facility Compliance Act}

The Federal Facility Compliance Act waives sovereign immunity with respect to RCRA for federal facilities (42 USC § 6961). The act gives EPA, and authorized states, authority to conduct annual inspections of federal facilities and establishes requirements for management of hazardous/mixed waste.

SNL/CA is not subject to a site-specific federal facility compliance agreement for mixed waste. The site does not possess or store any legacy mixed waste. All mixed waste generated at SNL/CA during 2006 was appropriately managed under the site's RCRA Hazardous Waste Facility Permit.

\subsubsection{Resource Conservation and Recovery Act}

RCRA regulates the generation, transportation, treatment, storage, and disposal of hazardous chemical waste, non-hazardous solid waste, and hazardous or petroleum products stored in 
USTs (42 USC $§ 6901$ et. seq.). The State of California has authority from the EPA to implement RCRA. The DTSC administers most aspects of RCRA in the state, and is the regulating authority for hazardous waste operations at SNL/CA, including the hazardous component of radioactive mixed waste.

SNL/CA operates a Hazardous Waste Treatment and Storage Facility under a RCRA Hazardous Waste Facility Permit issued by DTSC on March 30, 2004. The permit is effective through March 2014 and allows for storage and treatment of hazardous waste.

By definition, SNL/CA is a large quantity generator of RCRA waste. As such, the site is required under RCRA standards and implementing regulations (40 CFR 262.41) to submit a biennial report to EPA. The 2006 biennial report was submitted in February 2006 and provided information about the quantity of RCRA hazardous waste generated, stored, and shipped during the 2005 reporting period.

SNL/CA received one minor violation from DTSC in 2006. The violation concerned incomplete documentation related to the RCRA permit. Corrective actions were taken immediately; no fines were assessed. Additional information is provided in Section 3.13.

\subsubsection{California Hazardous Waste Control Law}

The Hazardous Waste Control Law (California Health and Safety Code §25100 et. seq.) provides a separate regulatory framework for hazardous waste management in California. The state law incorporates all RCRA requirements and imposes additional requirements that are broader and more comprehensive than the federal system. Under the California law, additional waste materials (e.g., oils, metals, asbestos) or activities (e.g., treatment) are regulated as hazardous. State standards are incorporated into SNL/CA's Waste Management Program so that California regulated waste is managed as hazardous waste in compliance with state requirements.

The California Environmental Health Standards for Management of Hazardous Waste (22 CCR, Division 4.5) requires all permitted hazardous waste facilities to submit an annual facility report to DTSC. Annual facility reports provide information about the quantity of RCRA and California designated hazardous waste generated and stored at SNL/CA, and the quantity of waste shipped from the site. A separate annual facility report for the 2005 calendar year was not requested by DTSC in 2006 because the biennial report submitted to EPA (see Section 3.8.2) satisfied the reporting requirement. An annual report for the 2006 calendar year will be submitted to DTSC in 2007.

\subsubsection{Medical Waste Management Act}

The California Medical Waste Management Act (California Health and Safety Code, Division 104, Part 14, §§ 117600-118360) provides for regulation of medical waste generators, transporters, and treatment facilities. The Alameda County Department of Environmental Health is the regulating authority for medical waste generated at SNL/CA. SNL/CA has two facilities identified as small quantity generators of medical waste, one with limited onsite treatment and one without onsite treatment. 


\subsection{Radiation Protection}

\subsubsection{Atomic Energy Act}

The purpose of the Atomic Energy Act is to assure the proper management of nuclear materials and radioactive waste (42 USC § 2011 et. seq.). The act allows DOE to set radiation protection standards to control exposure to the public and the environment that may result from operations at DOE facilities. DOE sets these standards through department directives or orders. Operations at SNL/CA are subject to the requirements established in DOE Order 435.1, Radioactive Waste Management (DOE 2001) and DOE Order 5400.5, Radiation Protection of the Public and the Environment (DOE 1993).

\subsubsection{DOE Order 435.1, Radioactive Waste Management}

DOE Order 435.1 establishes requirements to manage radioactive waste in a manner that protects the environment, and worker and public health and safety. Under this order, DOE contractor operated facilities are required to plan, document, execute, and evaluate the management of radioactive waste. Requirements of Order 435.1 are incorporated into the SNL/CA radioactive waste management element of the Waste Management Program. The program includes certification and characterization of waste; provisions for inspections and audits; training requirements; and operating procedures for handling, storing, packaging, shipping, and offsite disposal of radioactive waste.

SNL/CA generates low-level radioactive waste and low-level mixed waste. No transuranic or high-level radioactive waste is generated by SNL/CA operations. Radioactive wastes are stored onsite in the Radioactive Waste Treatment and Storage Facility. Low-level waste is shipped offsite for land disposal at the Nevada Test Site. Low-level mixed waste is managed under RCRA and shipped offsite for disposal at commercial disposal sites in compliance with site-specific waste acceptance criteria.

\subsubsection{DOE Order 5400.5, Radiation Protection of the Public and the Environment}

DOE Order 5400.5 sets radiation protection standards for DOE operations so that radiation exposures to members of the public and the environment are as low as reasonably achievable (ALARA) and maintained within established limits of the order. Table 3-2 provides a summary of SNL/CA compliance with this order in 2006.

\subsection{Water Quality and Protection}

SNL/CA is subject to the requirements of the Clean Water Act and equivalent California statutes. SNL/CA does not operate a public water system, and is not involved in any environmental restoration activities for which Safe Drinking Water Act standards are being applied. 
Drinking water at SNL/CA is purchased through LLNL and obtained from the San Francisco Water District or the Alameda County Flood Control and Water Conservation District, Zone 7. The San Francisco Water District and Zone 7 are responsible for monitoring the quality of the incoming water. SNL/CA is not required to treat or sample the drinking water. LLNL maintains the drinking water distribution system for both sites and screens for water quality (SNL/CA 2002).

Table 3-2 Order 5400.5 Compliance Summary, 2006

\begin{tabular}{|c|c|}
\hline Order 5400.5 Requirement & SNL/CA 2006 Summary \\
\hline $\begin{array}{l}\text { Maximum exposure to members of public }=100 \\
\mathrm{mrem} / \mathrm{yr}\end{array}$ & $\begin{array}{l}\text { There were no radionuclide emissions in } 2006 \text {. } \\
\text { The average annual gamma radiation } \\
\text { measurement at the site perimeter in } 2006 \text { was } 62 \\
\text { mrem, or } 7 \text { mrem more than distant locations, } \\
\text { where the average annual dose was } 55 \text { mrem. The } \\
\text { difference between perimeter and distant locations } \\
\text { is most likely the result of normal fluctuations and } \\
\text { natural variations in ambient radiation. }\end{array}$ \\
\hline Adopt ALARA exposures & $\begin{array}{l}\text { ALARA is incorporated into ES\&H policy, } \\
\text { ES\&H manual, and site operating procedures. }\end{array}$ \\
\hline $\begin{array}{l}\text { Control release of liquid radioactive wastes to the } \\
\text { environment }\end{array}$ & $\begin{array}{l}\text { No intentional discharges of liquid wastes to the } \\
\text { environment occur onsite. No accidental releases } \\
\text { of liquid radioactive waste occurred in } 2006 \text {. }\end{array}$ \\
\hline Control burial of low-level waste & $\begin{array}{l}\text { Disposal of low-level waste does not occur onsite. } \\
\text { ES\&H procedures, manuals, and management } \\
\text { systems are incorporated into site operations to } \\
\text { ensure proper handling, and disposal of } \\
\text { radioactive materials offsite at approved facilities. }\end{array}$ \\
\hline Control radioactive releases to the sanitary sewer & $\begin{array}{l}\text { Radioactive releases to the sanitary sewer above } \\
\text { DOE } 5400.5 \text { guidelines are not allowed at } \\
\text { SNL/CA. ES\&H procedures, manuals, and } \\
\text { management systems are incorporated into site } \\
\text { operations to ensure proper handling and disposal } \\
\text { of radioactive materials. }\end{array}$ \\
\hline $\begin{array}{l}\text { Implement environmental monitoring and } \\
\text { surveillance }\end{array}$ & $\begin{array}{l}\text { An environmental monitoring and surveillance } \\
\text { program has been in place at SNL/CA for more } \\
\text { than } 30 \text { years. }\end{array}$ \\
\hline $\begin{array}{l}\text { Control the release of property with residual } \\
\text { radioactivity }\end{array}$ & $\begin{array}{l}\text { SNL/CA does not release any property to the } \\
\text { public with residual radioactivity above } \\
\text { authorized limits. Excess property of this type is } \\
\text { either transferred to other DOE facilities for reuse } \\
\text { or transferred to Waste Management for disposal. }\end{array}$ \\
\hline NESHAPS Dose evaluations & $\begin{array}{l}\text { There were no airborne radionuclide emission } \\
\text { sources in 2006; therefore, there is no monitoring } \\
\text { data available for dose evaluations. }\end{array}$ \\
\hline
\end{tabular}

\subsubsection{Clean Water Act}

The Clean Water Act regulates all direct discharges into navigable waters of the United States (U.S.) (33 USC $\S 1251$ ). Direct discharges to waters of the U.S. require permits issued under the National Pollutant Discharge Elimination System (NPDES). In California, the State 
Water Resources Control Board has authority from EPA to implement the Clean Water Act. Federal permitting requirements are included in Waste Discharge Requirements issued by Regional Water Quality Control Boards.

\section{Wastewater Discharge}

Wastewater generated at SNL/CA is discharged to the City of Livermore Water Reclamation Plant, a publicly owned treatment works (POTW). The Livermore POTW maintains an NPDES permit, and then regulates industry discharges into their sewer system. A Wastewater Discharge Permit issued by the Livermore POTW regulates SNL/CA's wastewater discharges. The permit is updated annually and includes discharge limits for the site sanitary sewer outfall and for processes subject to EPA pretreatment standards. During 2006, SNL/CA did not exceed established discharge limits at the sewer outfall.

SNL/CA has three categorical processes that are subject to EPA's pretreatment standards: two metal finishing operations, and a semiconductor manufacturing operation. The two metal finishing operations are closed-loop processes and do not discharge any effluents. Wastewater generated from the semiconductor manufacturing process is sampled and monitored as part of the Environmental Monitoring Program. There were no exceedances of the discharge limits from this source during 2006.

\section{Storm Water Discharge}

General storm water discharges at SNL/CA are covered under the State of California NPDES General Permit for Storm Water Discharge Associated with Industrial Activities (General Permit) (California Water Resources Control Board 1997). The General Permit requires SNL/CA to implement a storm water pollution prevention plan. The SNL/CA plan describes the rationale for monitoring discharge locations and identifies best management practices for reducing pollutant contact with storm water.

SNL/CA's storm water management program also incorporates the six minimum control measures required by the California Small Municipal Separate Storm Sewer System (MS4) General Permit. The MS4 General Permit was adopted in 2003 to meet EPA Phase II storm water regulations. Although the MS4 General Permit is not yet a regulatory requirement for SNL/CA, the site anticipates that it will be regulated as a non-traditional small MS4 when notification is provided by the regulating agency.

In 2006, SNL/CA visually monitored 21 storm water discharge locations and sampled nine locations. The result of monitoring and sampling activities conducted in 2006 did not identify any issues of concern. Section 5.1 presents a summary of 2006 results. 


\subsection{Executive Order 13148}

Executive Order 13148, Greening of the Government Through Leadership in Environmental Management (EO 13148) ${ }^{4}$ directs federal agencies to integrate environmental accountability into day-to-day decision making and long-term planning processes. Table 3-3 presents the activities conducted at SNL/CA in support of this executive order.

Table 3-3 SNL/CA Activities in Support of Executive Order 13148

\begin{tabular}{l} 
E.O. 13148 Goal \\
Develop and implement environmental management \\
system (EMS) \\
\hline Establish and implement environmental compliance audit \\
programs and policies that emphasize pollution prevention
\end{tabular}
SNL/CA Activity

EMS documented and implemented in 2005. EMS program certified to ISO 14001 in 2006.

Establish and implement environmental compliance audit
programs and policies that emphasize pollution prevention SNL/CA's ES\&H Interdisciplinary Team process ensures that each new and modified project is evaluated for pollution prevention and waste minimization opportunities. Additionally, SNL/CA maintains a PP/WM Program that periodically conducts pollution prevention opportunity assessments, and assists site customers in implementing new processes to reduce pollution and waste.

\begin{tabular}{l}
\hline EPCRA Reporting \\
\hline Reduce EPCRA 313 reported Toxic Release Inventory \\
(TRI) releases and off-site transfers of toxic chemicals for \\
treatment and disposal
\end{tabular}
Conducted annually.

SNL/CA meets the TRI reporting threshold for lead only. Lead releases are generated from activities at the firing range. To reduce TRI releases, a change in ammunition type would be required. Because NNSA/SSO dictates the ammunition type used at SNL/CA, any changes would need to come from NNSA/SSO.

Reduce use of toxic chemicals, hazardous substances, and pollutants, or generation of hazardous and radioactive waste types

SNL/CA maintains a PP/WM Program to identify waste minimization opportunities and to assist site customers in implementing new processes to reduce pollution and waste.

Reduce use of ozone-depleting substances (ODS)

SNL/CA complies with the regulations contained in 40 CFR 82 that are designed to end production of ODS, support recycling of ODS during servicing and disposal, and identify alternatives for ODS.

Promote sustainable management of federal lands through cost-effective, environmentally sound landscaping practices, and programs to reduce adverse impacts to the natural environment

Site landscaping practices follow the SNL/CA Visual Quality Guidelines and Landscape Master Plan that incorporates the use of drought tolerant and native plant species into landscape design.

\subsection{Audits, Assessments, and Inspections}

Table 3-4 provides a list of environmental program audits, assessments, and/or inspections conducted at SNL/CA during 2006.

\footnotetext{
${ }^{4}$ On January 24, 2007, EO 13423 was issued. This new executive order revokes and consolidates five executive orders, including EO 13148.
} 


\subsection{Environmental Occurrences}

SNL/CA had one environmental occurrence in 2006 involving incomplete documentation associated with the site RCRA Hazardous Waste Facility Permit. On August 16, 2006, SNL/CA received an inspection report from DTSC identifying three minor violations observed during a facility inspection conducted on March 29 and 30, 2006. This was later revised to one minor violation upon detailed review by DTSC and SNL/CA in a meeting at DTSC on November 6, 2006. The permit update to correct this minor violation is pending DTSC approval. The violation is that Sandia's weekly facility inspection form did not include the inspection time and full name of the inspector.

Table 3-4 SNL/CA Audits, Assessments, and Inspections, 2006

\begin{tabular}{|c|c|c|c|}
\hline Title & Area of Focus & Date Conducted & Results \\
\hline Alameda County Inspection & $\begin{array}{l}\text { Erosion at the Navy Landfill } \\
\text { site }\end{array}$ & December 21, 2006 & No violations \\
\hline $\begin{array}{l}\text { City of Livermore, Water } \\
\text { Resources Division } \\
\text { Inspections }\end{array}$ & $\begin{array}{l}\text { Wastewater discharges and } \\
\text { categorical process } \\
\text { laboratories }\end{array}$ & August 23-24, 2006 & No violations \\
\hline $\begin{array}{l}\text { California Department of } \\
\text { Toxic Substances Control } \\
\text { Inspection }\end{array}$ & $\begin{array}{l}\text { Hazardous Waste Facility, } \\
\text { RCRA permit compliance }\end{array}$ & March 29 -31, 2006 & $\begin{array}{l}1 \text { minor } \\
\text { administrative } \\
\text { violation }\end{array}$ \\
\hline $\begin{array}{l}\text { Third Party Environmental } \\
\text { Management System (EMS) } \\
\text { Audit (NSF-ISR) }\end{array}$ & $\begin{array}{l}\text { Conformance with the ISO } \\
\text { 14001:2004 EMS standard }\end{array}$ & $\begin{array}{l}\text { September 19-21, } \\
2006\end{array}$ & $\begin{array}{l}\text { SNL/CA EMS } \\
\text { Program Certified } \\
\text { under ISO } \\
\text { 14001:2004 }\end{array}$ \\
\hline $\begin{array}{l}\text { Pollution Prevention } \\
\text { Program Review } \\
\text { (NNSA/SSO) }\end{array}$ & $\begin{array}{l}\text { All components of the } \\
\text { PP/WM Program }\end{array}$ & $\begin{array}{l}\text { September 26-27, } \\
2006\end{array}$ & $\begin{array}{l}\text { No concerns } \\
\text { identified. }\end{array}$ \\
\hline $\begin{array}{l}\text { Environmental Permitting } \\
\text { Process Audit (SNL } \\
\text { corporate) }\end{array}$ & $\begin{array}{l}\text { Process for environmental } \\
\text { permit applications / } \\
\text { modifications }\end{array}$ & October 30, 2006 & $\begin{array}{l}2 \text { concerns applicable } \\
\text { to SNL/CA; } 2 \\
\text { SNL/CA strengths }\end{array}$ \\
\hline
\end{tabular}

\subsection{Permits}

Environmental permits and clean-up orders held by SNL/CA are listed in Table 3-5. Additional information is provided in previous sections under the relative program or regulation. 
Table 3-5 SNL/CA Environmental Permits and Orders, 2006

\begin{tabular}{|c|c|c|c|c|}
\hline Type & Description & Effective Date & $\begin{array}{l}\text { Statute / } \\
\text { Regulation }\end{array}$ & Issuing Agency \\
\hline $\begin{array}{l}\text { Environmental } \\
\text { restoration }\end{array}$ & $\begin{array}{l}\text { Site Clean-up Order No. } \\
\text { 89-184 }\end{array}$ & $\begin{array}{l}\text { December } 1989 \text { (no } \\
\text { expiration date) }\end{array}$ & $\begin{array}{l}\text { California Water } \\
\text { Code }\end{array}$ & $\begin{array}{l}\text { Regional Water Quality } \\
\text { Control Board, San } \\
\text { Francisco Bay }\end{array}$ \\
\hline $\begin{array}{l}\text { Hazardous } \\
\text { materials }\end{array}$ & $\begin{array}{l}\text { Business Plan Permit to } \\
\text { Operate }\end{array}$ & $\begin{array}{l}\text { November 1, } 2006 \text { - } \\
\text { October 31, } 2007\end{array}$ & $\begin{array}{l}\text { California Health } \\
\text { and Safety Code }\end{array}$ & $\begin{array}{l}\text { Alameda County } \\
\text { Environmental Health } \\
\text { Department }\end{array}$ \\
\hline Hazardous waste & $\begin{array}{l}\text { RCRA Hazardous Waste } \\
\text { Facility Permit }\end{array}$ & $\begin{array}{l}\text { March } 2004 \text { - } \\
\text { March } 2014\end{array}$ & $\begin{array}{l}\text { Resource } \\
\text { Conservation and } \\
\text { Recovery Act } \\
\end{array}$ & $\begin{array}{l}\text { California Department of } \\
\text { Toxic Substances Control }\end{array}$ \\
\hline Hazardous waste & Permit by Rule & $\begin{array}{l}\text { November 1, } 2006 \text { - } \\
\text { October 31, } 2007\end{array}$ & $\begin{array}{l}\text { California Health } \\
\text { and Safety Code }\end{array}$ & $\begin{array}{l}\text { Alameda County } \\
\text { Environmental Health } \\
\text { Department }\end{array}$ \\
\hline Hazardous waste & $\begin{array}{l}\text { Conditionally Authorized } \\
\text { Permit to Operate }\end{array}$ & $\begin{array}{l}\text { November 1, } 2006 \text { - } \\
\text { October 31, } 2007\end{array}$ & $\begin{array}{l}\text { California Health } \\
\text { and Safety Code }\end{array}$ & $\begin{array}{l}\text { Alameda County } \\
\text { Environmental Health } \\
\text { Department }\end{array}$ \\
\hline Medical waste & $\begin{array}{l}\text { Small Quantity Generator } \\
\text { with Onsite Treatment }\end{array}$ & $\begin{array}{l}\text { August 9, } 2006 \text { - } \\
\text { August 8, } 2007\end{array}$ & $\begin{array}{l}\text { California Health } \\
\text { and Safety Code }\end{array}$ & $\begin{array}{l}\text { Alameda County } \\
\text { Environmental Health } \\
\text { Department }\end{array}$ \\
\hline Medical waste & $\begin{array}{l}\text { Small Quantity Generator } \\
\text { without Onsite Treatment }\end{array}$ & $\begin{array}{l}\text { April 11, } 2006 \text { - } \\
\text { April 10, } 2007\end{array}$ & $\begin{array}{l}\text { California Health } \\
\text { and Safety Code }\end{array}$ & $\begin{array}{l}\text { Alameda County } \\
\text { Environmental Health } \\
\text { Department }\end{array}$ \\
\hline Wastewater & $\begin{array}{l}\text { Wastewater Discharge } \\
\text { Permit }\end{array}$ & $\begin{array}{l}\text { August 4, } 2006 \text { - } \\
\text { August 3, } 2007\end{array}$ & Clean Water Act & $\begin{array}{l}\text { City of Livermore Water } \\
\text { Reclamation Plant }\end{array}$ \\
\hline Storm water & $\begin{array}{l}\text { State of California General } \\
\text { Industrial Permit }\end{array}$ & $\begin{array}{l}\text { July } 1997 \text { - July } \\
2002^{\text {a }}\end{array}$ & Clean Water Act & $\begin{array}{l}\text { California Water } \\
\text { Resources Control Board }\end{array}$ \\
\hline $\begin{array}{l}\text { Jurisdictional } \\
\text { waters of the U.S. }\end{array}$ & $\begin{array}{l}\text { Nationwide Permit } \\
\text { Authorization }\end{array}$ & $\begin{array}{l}\text { July 14, } 2005- \\
\text { March 18, } 2007\end{array}$ & Clean Water Act & Army Corp of Engineers \\
\hline $\begin{array}{l}\text { Underground } \\
\text { storage tank }\end{array}$ & Permit to Operate & $\begin{array}{l}\text { November 1, } 2006 \text { - } \\
\text { October 31, } 2007\end{array}$ & $\begin{array}{l}\text { Resource } \\
\text { Conservation and } \\
\text { Recovery Act and } \\
\text { California Health } \\
\text { and Safety Code } \\
\end{array}$ & $\begin{array}{l}\text { Alameda County } \\
\text { Environmental Health } \\
\text { Department }\end{array}$ \\
\hline $\begin{array}{l}\text { Aboveground } \\
\text { storage tanks }\end{array}$ & Storage statement & $\begin{array}{l}\text { July 1, } 2006 \text { - June } \\
\text { 30, } 2007\end{array}$ & $\begin{array}{l}\text { Aboveground } \\
\text { Petroleum Storage } \\
\text { Act }\end{array}$ & $\begin{array}{l}\text { California Water } \\
\text { Resources Control Board }\end{array}$ \\
\hline Air & $\begin{array}{l}\text { Permit to Operate } 15 \\
\text { emission sources: } \\
1 \text { degreaser; } 1 \text { paint spray } \\
\text { booth; } 1 \text { non-retail gasoline } \\
\text { dispensing facility; } 1 \\
\text { chromium electroplating } \\
\text { operation; } 5 \text { miscellaneous } \\
\text { (decontamination sink, } \\
\text { waste compactor, drum } \\
\text { crusher, two site wide } \\
\text { sources for solvent } \\
\text { emissions); } 6 \text { emergency } \\
\text { generators }\end{array}$ & $\begin{array}{l}\text { July 1, } 2006 \text { - June } \\
30,2007\end{array}$ & Clean Air Act & $\begin{array}{l}\text { Bay Area Air Quality } \\
\text { Management District }\end{array}$ \\
\hline
\end{tabular}




\section{Environmental Management}

Sandia National Laboratories, California (SNL/CA) is firmly committed to sound environmental stewardship practices as well as compliance with environmental requirements. SNL/CA meets this commitment through an environmental management system (EMS) that integrates traditional environmental program elements with objectives for improving the environmental footprint of site operations. The site's EMS program is dynamic, encompassing an annual cycle of planning, implementing, assessing, and improving operations in support of site-specific environmental goals.

SNL/CA's EMS program conforms to the international standard for environmental management systems, ISO 14001. In September 2006, an independent third-party registrar completed an audit of SNL/CA's EMS that resulted in a recommendation for registration under the standard. On September 25, 2006 the site received ISO 14001:2004 certification. To ensure that the site maintains conformance with the standard, surveillance audits will be conducted every six months by a third-party registrar, and recertification is required every three years. SNL/CA is the first Sandia division to receive ISO 14001 certification.

\subsection{EMS Elements}

SNL/CA Environment, Safety, and Health (ES\&H) Standard of Performance

SNL/CA is firmly committed to meeting all corporate and regulatory ES\&H policies and requirements that apply to its operations. The application of compliant ES\&H principles and practices is considered a fundamental element of everyone's work assignment.

In this regard, SNL/CA commits to:

$>\quad$ Nurture a safety and health conscious work ethic and culture. We will all assume responsibility for creating and maintaining a worksite, as well as performing our work, in a manner that respects and supports the safety and health of every individual. SNL/CA believes that all accidents are preventable. We will all strive to create a workplace that is free of accidents and injuries.

$>\quad$ Be a responsible steward of the environmental resources in our care. We will integrate environmental risk assessment, planning and impact mitigation into every aspect of our work. SNL/CA programs, operations, processes, and facilities will be planned and managed such that they support environmental objectives and targets to minimize the creation of waste, pollution, and adverse impact on the public and the environment. SNL/CA will remain committed to an efficient and effective Environmental Management System as part of the laboratory’s Integrated Safety Management System.

$>$ Comply with all applicable laws, regulations and permits. Compliance with the letter and the spirit of ES\&H laws and regulations is viewed as the minimum acceptable standard. When necessary and appropriate we will go beyond legal mandates in order to implement more effective approaches and to nurture a positive and learning ES\&H culture. SNL/CA is committed to continual improvement in all aspects of our environment, safety, and health performance and commits to establish performance indicators to guide these efforts and measure our progress.

SNL/CA's EMS Program encompasses the seventeen elements of an effective EMS Program as identified in the ISO 14001 standard. The ISO elements overlap with those of Department of Energy (DOE) Order 450.1, thus SNL/CA's EMS Program also meets the DOE requirements. Table 4-1 identifies the EMS elements and summarizes the methods, tools, and programs implemented in support of each. 
Table 4-1 Elements of the SNL/CA EMS Program

EMS Element Implementation Summary

SNL/CA operates under a site-specific ES\&H standard of performance that reinforces

Environmental individual accountability, environmental stewardship, and compliance. SNL/CA stresses the

policy need to move beyond compliance to nurturing of a positive ES\&H culture at all levels of the workforce. 


\begin{tabular}{|c|c|}
\hline EMS Element & Implementation Summary \\
\hline $\begin{array}{l}\text { Environmental } \\
\text { programs }\end{array}$ & $\begin{array}{l}\text { SNL/CA's EMS Program is supported by six functional environmental programs. } \\
>\text { Air Quality } \\
>\text { Environmental Monitoring and Restoration } \\
>\text { Environmental Planning and Ecology } \\
>\text { Hazardous Materials Management } \\
>\text { Pollution Prevention and Waste Minimization } \\
>\text { Waste Management }\end{array}$ \\
\hline $\begin{array}{l}\text { Structure, } \\
\text { responsibilities, } \\
\text { and authorities }\end{array}$ & $\begin{array}{l}\text { SNL/CA's EMS Program is implemented through existing site management and } \\
\text { organizational structures. The site Vice President holds overall responsibility for success of } \\
\text { the EMS Program. Director and senior management personnel ensure availability of } \\
\text { resources. An environmental management representative and EMS core team are responsible } \\
\text { for day-to-day management of the program. All members of the workforce hold } \\
\text { responsibility and authority to implement EMS elements into their operations. }\end{array}$ \\
\hline $\begin{array}{l}\text { Competence, } \\
\text { training, and } \\
\text { awareness }\end{array}$ & $\begin{array}{l}\text { SNL/CA employs a variety of mechanisms to ensure that the site workforce and visitors } \\
\text { maintain the appropriate training and competence levels for their assignments, and to foster } \\
\text { awareness. These mechanisms include corporate training programs, site-specific training } \\
\text { programs, and activity-specific training programs. For contractor-directed activities that } \\
\text { occur on site, SNL/CA issues standard specifications that identify training, credentials, and } \\
\text { certifications required for each project. }\end{array}$ \\
\hline Communication & $\begin{array}{l}\text { SNL/CA communicates EMS information internally through project review teams, an EMS } \\
\text { Advisory Team, publications, websites, briefings, assessments, and promotional } \\
\text { information. Information is communicated externally through publications, websites, } \\
\text { SNL/CA's Public and Media Relations Office, and regulatory-driven documents. }\end{array}$ \\
\hline $\begin{array}{c}\text { EMS } \\
\text { documentation }\end{array}$ & $\begin{array}{l}\text { SNL/CA maintains an EMS Program Manual as the primary EMS document for the site. } \\
\text { General corporate and site policies, document systems, and databases provide supporting } \\
\text { documentation for the EMS Program. }\end{array}$ \\
\hline $\begin{array}{c}\text { Document } \\
\text { control }\end{array}$ & $\begin{array}{l}\text { At SNL/CA, document control is accomplished with electronic documents that are available } \\
\text { in online databases at the point of use. Permits and other regulatory documents of external } \\
\text { origin are typically marked as valid for a specified period and controlled by limited } \\
\text { distribution coordinated by environmental program leads. In the last year, Sandia } \\
\text { implemented improvements in the document control process by adding a change summary to } \\
\text { EMS program and technical work documents when updated. }\end{array}$ \\
\hline $\begin{array}{l}\text { Operational } \\
\text { controls }\end{array}$ & $\begin{array}{l}\text { Sandia employs an integrated system to address ES\&H concerns associated with site } \\
\text { operations. This integrated system provides the framework for planning work, evaluating } \\
\text { hazards, identifying controls, conducting work, and improving work processes. Unique to } \\
\text { SNL/CA, the ES\&H, Facilities, and Security Interdisciplinary Team supports integrated } \\
\text { safety and environmental management to ensure requirements and controls are identified } \\
\text { during project planning. Typical operational controls used at SNL/CA include technical } \\
\text { work documents, environmental permits and compliance documents, contract specifications, } \\
\text { and a variety of engineered controls. }\end{array}$ \\
\hline $\begin{array}{l}\text { Emergency } \\
\text { preparedness } \\
\text { and response }\end{array}$ & $\begin{array}{l}\text { An established Emergency Management Program that maintains responsibility for } \\
\text { preparedness and response supports SNL/CA's EMS Program. Emergency Management } \\
\text { conducts routine drills and communication tests, and annually conducts site-wide training } \\
\text { exercises. Environmental representatives are active members of emergency response teams } \\
\text { to ensure that potential environmental risks are managed and mitigated appropriately. }\end{array}$ \\
\hline $\begin{array}{l}\text { Monitoring and } \\
\text { measurement }\end{array}$ & $\begin{array}{l}\text { Each of the six SNL/CA functional environmental programs monitors and measures the key } \\
\text { characteristics of site operations that can affect the environment. Data collected supports } \\
\text { compliance requirements as well as assessment of the site's overall progress in meeting } \\
\text { EMS objectives. Monitoring data and metrics are available to the public in annual } \\
\text { environmental reports. }\end{array}$ \\
\hline $\begin{array}{l}\text { Evaluating } \\
\text { compliance }\end{array}$ & $\begin{array}{l}\text { SNL/CA evaluates compliance with all environmental requirements through the } \\
\text { Interdisciplinary Team process, self-assessments, and audits. }\end{array}$ \\
\hline
\end{tabular}




\begin{tabular}{cl}
\hline EMS Element & Implementation Summary \\
\hline $\begin{array}{c}\text { Nonconformity, } \\
\text { corrective, and } \\
\text { preventive } \\
\text { action }\end{array}$ & $\begin{array}{l}\text { During 2006, SNL/CA implemented improvements in documenting, tracking, and verifying } \\
\text { corrective and preventive actions with electronic assessment tracking and corrective action } \\
\text { systems. The EMS Core Team also established a procedure for validating the effectiveness } \\
\text { of select actions and reduce the potential for recurrence of significant nonconformities. }\end{array}$ \\
\hline \multirow{2}{*}{ Records } & $\begin{array}{c}\text { All information created by Sandia operations is managed as a record. ES\&H information } \\
\text { created at SNL/CA is managed by the site ES\&H Records Center. }\end{array}$ \\
\hline \multirow{2}{*}{$\begin{array}{c}\text { Management } \\
\text { review }\end{array}$} & $\begin{array}{l}\text { SNL/CA's top management team (VP and directors) periodically review the EMS Program. } \\
\text { Two management reviews were completed in 2006 resulting in ten recommendations for }\end{array}$ \\
& $\begin{array}{c}\text { EMS improvement. Efforts are underway to implement recommendations to improve } \\
\text { communications, objectives, and targets. }\end{array}$ \\
\hline
\end{tabular}

\subsection{Environmental Performance}

SNL/CA measures the site's environmental performance by tracking progress towards achieving EMS objectives. Data is available to measure many EMS objectives, but not all. In 2006, the site measured performance towards achieving 14 of the 22 established objectives. The following diagrams and text summarize the site's progress and improvement in the last year. Table 4-1 provides the complete list of EMS objectives.

\section{Program Management Objective: Provide exceptional environmental management for the site}

SNL/CA tracks noncompliance with environmental requirements as a measure of our environmental management performance. Figure 4-1 shows the number of findings from third-party audits (includes DOE), notices of violation, and other environmental occurrences ${ }^{5}$

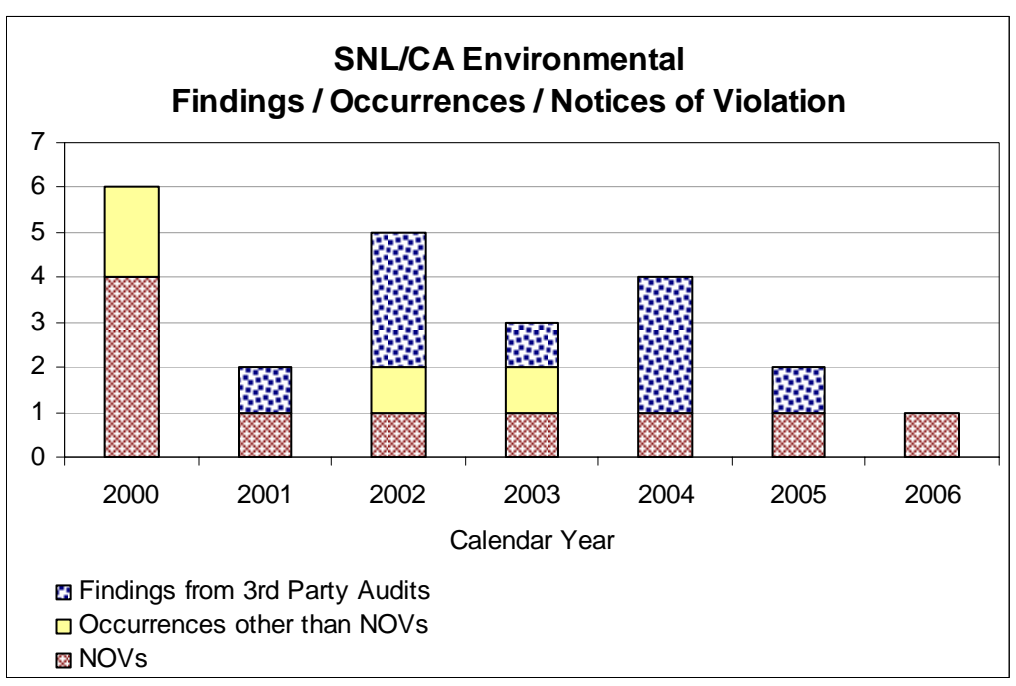

Figure 4-1 Measurement of Excellence in Environmental Management since 2000. The site goal is zero findings and zero violations. SNL/CA received one violation in 2006 but zero findings, an improvement over previous years. Sandia attributes the improvements achieved in the last two years (2005 and 2006) to implementation of a robust EMS program, modifications to the self-assessment process for environmental programs, and increased site awareness of environmental issues.

\footnotetext{
${ }^{5}$ All notices of violation are also environmental occurrences and are not counted as "other environmental occurrences".
} 
Certification and recognition of SNL/CA's EMS program provide another indicator of excellence in environmental management. SNL/CA became the first Sandia division to obtain ISO 14001:2004 certification for its EMS. By conforming to the ISO standard, SNL/CA integrates sound environmental stewardship practices with regulatory compliance to reduce the site's environmental footprint. Also in 2006, SNL/CA received two DOE Environmental Stewardship Awards for pollution prevention activities recognizing efforts to redistribute unused chemicals and recycle empty containers.

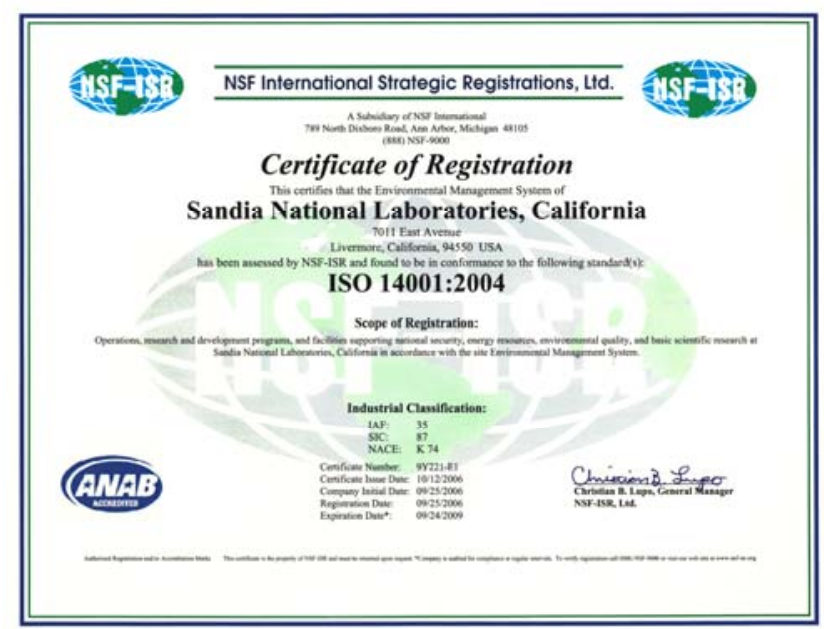

Water Discharge Objective: Minimize the volume and contamination of sewer water

SNL/CA continuously monitors wastewater generated on site. Figures 4-2 and 4-3 show the trend in weekly monitoring results since 2000 for copper and zinc, respectively. As shown, the site has experienced a gradual downward trend in levels of both copper and zinc at the sewer outfall. This trend indicates a steady improvement in the quality of sewer water effluent generated at SNL/CA. Efforts that support improvement in sewer water quality are described in Chapter 5, Environmental Monitoring. Also reflected on the graphs are SNL/CA's goals of maintaining the level of copper in the effluent at less than $0.3 \mathrm{mg} / \mathrm{L}$ and the level of zinc in the effluent at less than $1.0 \mathrm{mg} / \mathrm{L}$.

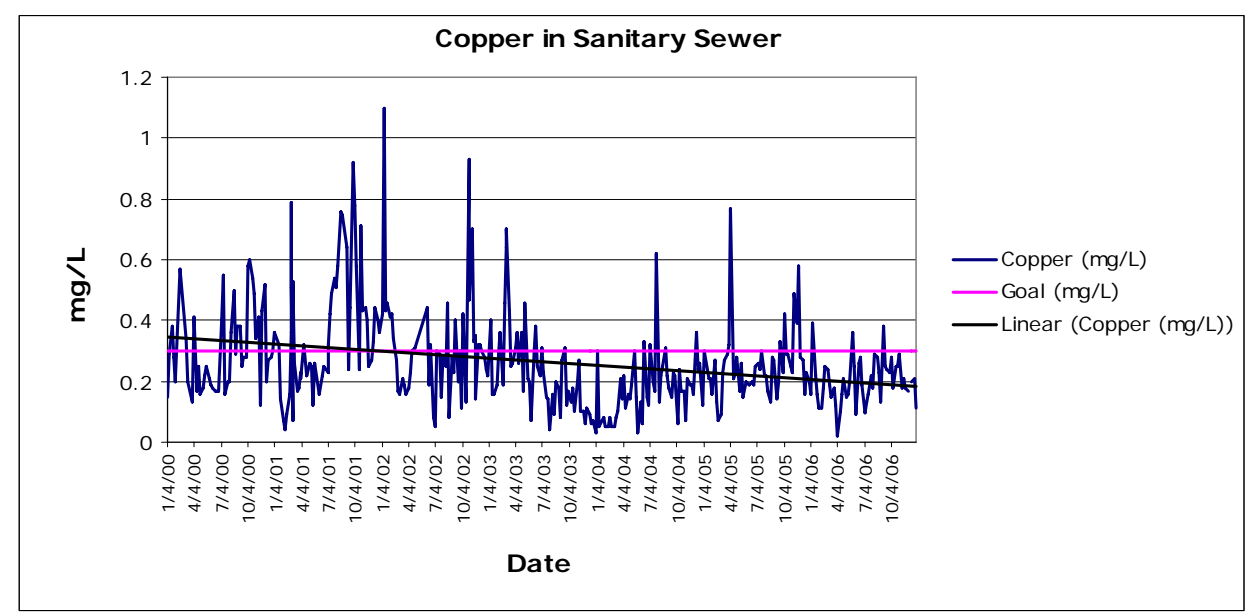

Figure 4-2 Weekly Composite Copper Concentrations in Wastewater 


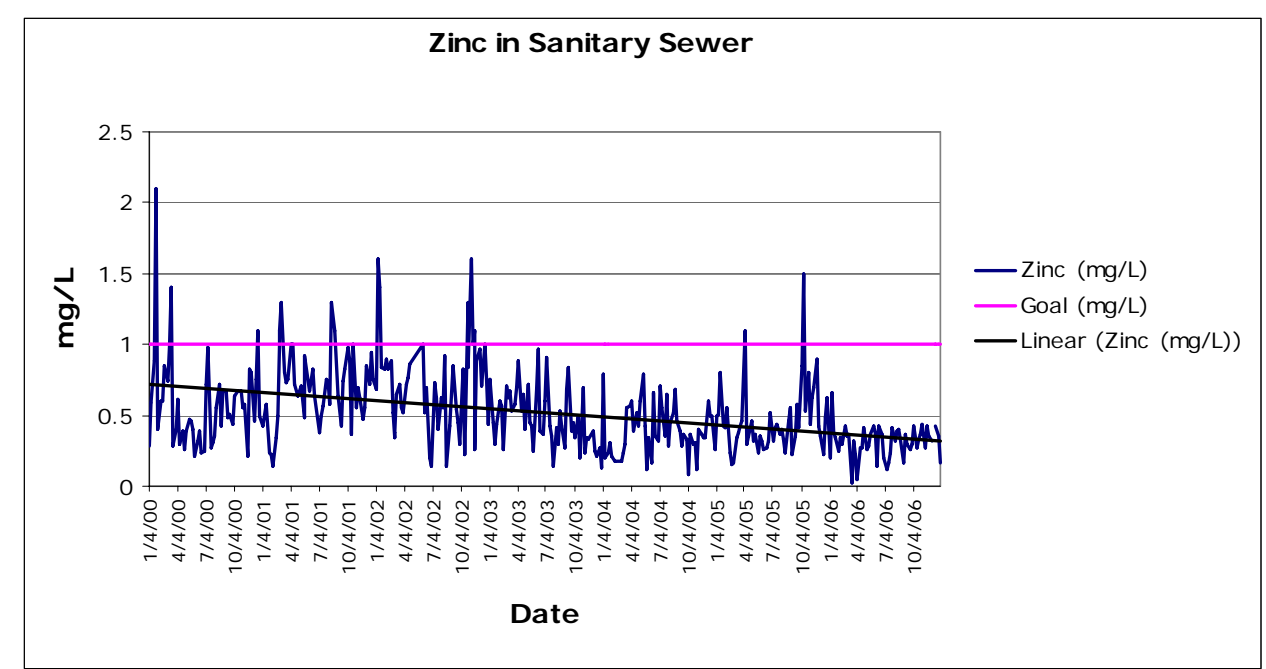

Figure 4-3 Weekly Composite Zinc Concentrations in Wastewater

Figure 4-4 shows volume of sewer effluent discharged by SNL/CA from 2000 through $2006 .{ }^{6}$ Sewer discharge in 2006 was 11.2 million gallons, approximately 800,000 gallons more than in 2005. SNL/CA has a stated goal of reducing the quantity of sewer effluent, although no numeric targets have been set.

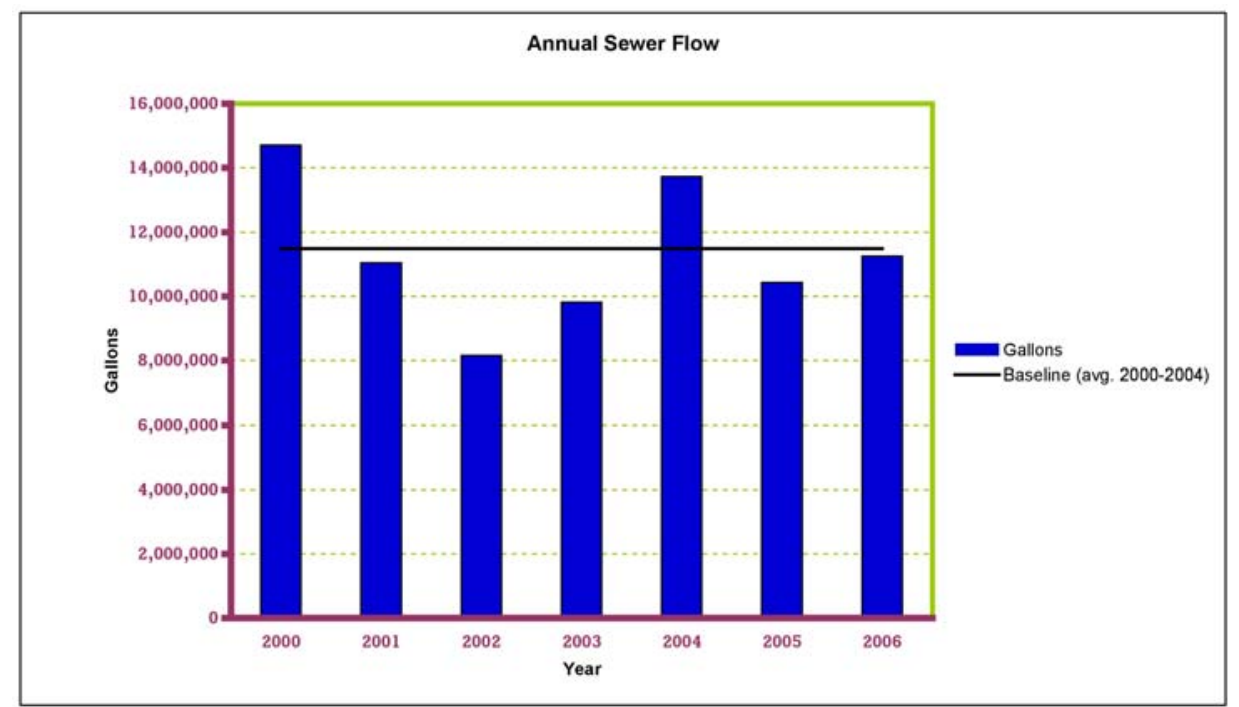

Figure 4-4 Annual Wastewater Discharges

\section{Water Discharge Objective: Minimize the volume and pollution of storm water runoff}

The State of California has not yet implemented numeric limits for pollutants in storm water. However, parameters such as total suspended solids (TSS) and oil and grease (O\&G) are indicative of the quality of storm water runoff from SNL/CA parking lots and roads. Many factors can affect the quantities of TSS and O\&G in the runoff, such as the length of dry

\footnotetext{
${ }^{6}$ The baseline measure displayed in Figure 4-4 is the average sewer flow from 2000 through 2004.
} 
weather before sample collection, volume of runoff during the storm, etc. Annually, SNL/CA clears debris from the storm water drainage system and sweeps streets to minimize pollutants in storm water runoff. In 2005 and 2006, Sandia collected approximately 250 cubic yards of debris during street cleaning efforts, thus removing potential storm water pollutants. Figure 4-5 shows the highest TSS and O\&G concentrations obtained at SNL/CA storm water sampling locations during the 2005/2006 rainy season. The concentration of TSS in storm water improved during 2005/2006 as the highest concentration $(160 \mathrm{mg} / \mathrm{L})$ was less than obtained during the 2004/2005 rainy season (520 mg/L). The concentration of O\&G in 2005/2006 (2.2 mg/L) was slightly higher than 2004/2005 levels (2.0 mg/L).

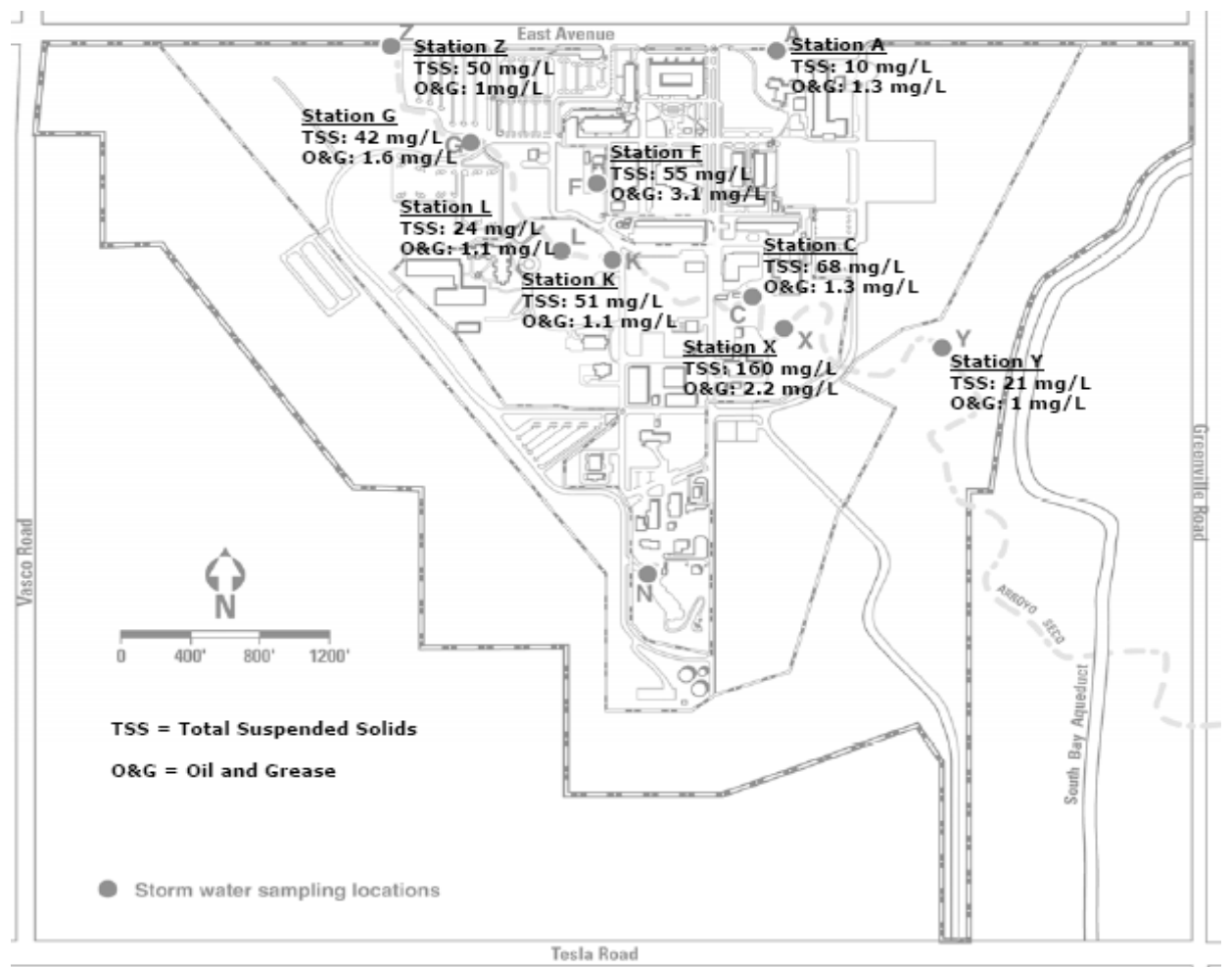

Figure 4-5 Constituents in Storm Water, 2005/2006 Rainy Season

\section{Air Emissions Objective: Minimize air emissions related to operations and transportation with emphasis on Spare the Air (STA) days}

During the summer of 2006, the Bay Area experienced several periods of unhealthy air quality, with the Bay Area Air Quality Management District (BAAQMD) issuing nine weekday STA advisories, compared to the 2005 STA season when just one weekday advisory was issued. Advisories are used to notify the public when air pollution is expected to reach unhealthy concentrations and to encourage Bay Area residents to take individual action to reduce harmful pollutants. In 2005, the Air Quality Program established an EMS target to reduce on-site fueling operations on STA days by 50 percent from the FY03/04 baseline. A program was developed and implemented that encourages site personnel to plan their gasoline fueling activities for either before or after a STA day. The site's workforce appears to be committed to meeting this target, as there were just 26 fill-ups over the nine STA days in 2006. This averages to less than three fill-ups per STA day, compared to an 
average of seven on a typical work day. Figure 4-6 shows the number of fill-ups on STA days over the last four years.

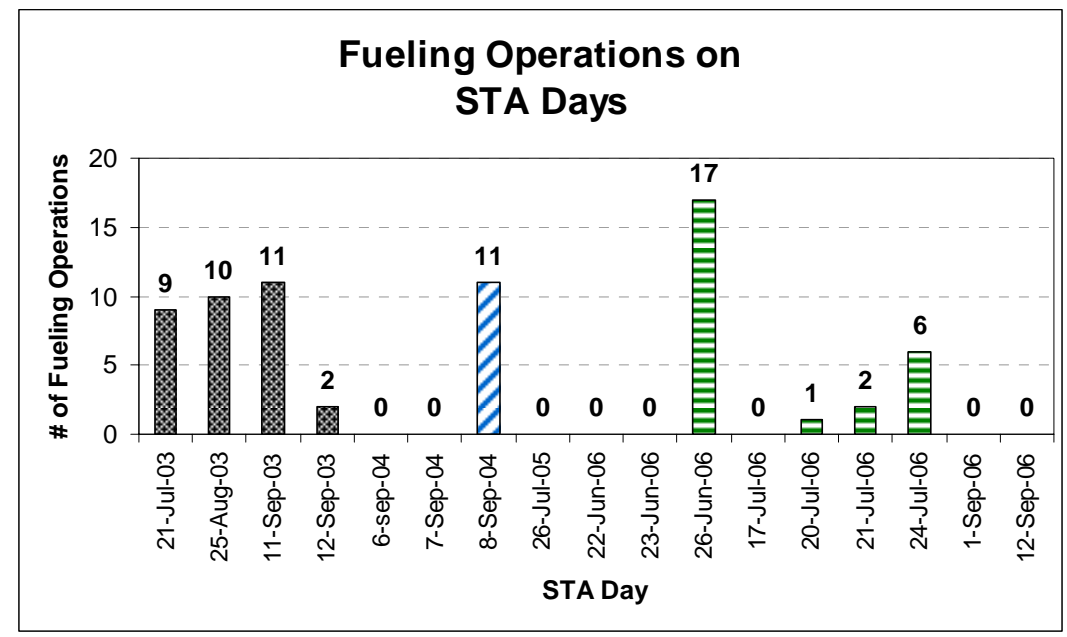

Figure 4-6 Number of Vehicle Fill-ups on STA Days ${ }^{7}$

SNL/CA has a second EMS target under the air emissions objective of reducing the site wide mobile source emissions by ten percent by the end of 2008. As a first step in meeting this target, the Air Quality Program established an emissions baseline for onsite mobile sources using 2004 data. $^{8}$ Onsite mobile sources include vehicles, carts, landscaping equipment, and construction and maintenance equipment that are not permanently attached to a stationary foundation.

In order to determine the progress in meeting this target, an annual follow-up analysis was completed using 2005 activity data ${ }^{9}$ (i.e., hours of operation or miles driven). The methodology, calculations, results and recommendations of this 2005 analysis are documented in the 2005 Emission Inventory of Mobile Sources Annual Progress Report (SNL/CA 2007). The estimated emissions of reactive organic gases (ROG), carbon monoxide (CO), nitrogen oxides (NOx), and respirable particulate matter $\left(\mathrm{PM}_{10}\right)$ and relative change between the 2004 baseline and 2005 are presented in Table 4-2.

SNL/CA's expectation was that very little would have changed between the baseline year (2004) and 2005 because implementation of plans to reduce site-wide mobile source emissions were just starting. In addition, the activity data for the baseline and the 2005 analysis are similar because the baseline incorporates some 2005 data (see footnote 8). The one significant change noted is the $18 \%$ reduction in total NOx emissions, which is largely attributed to the replacement of the 1990 street sweeper with a 2005 model. Other reductions $\left(\mathrm{PM}_{10}\right.$ by $3 \%$ ) and increases (ROG by $3 \%$ and $\mathrm{CO}$ by $2 \%$ ) are not, at this time, considered to

\footnotetext{
${ }^{7}$ In June 2006, the Bay Area experienced consecutive spare-the-air days, covering three consecutive workdays at SNL/CA. Site personnel deferred all fueling operations on the first two days, but were unable to sustain the delay on the third day, resulting in 17 fill-ups on June 26, 2006.

8 The 2004 baseline emission report (SNL, 2005) was completed in December 2005 and was in part based on 2005 data because complete 2004 data were not available.

${ }^{9} 2005$ activity data is the most current data available.
} 
be significant due to (1) the uncertainty and assumptions inherent in the emissions calculations and (2) the fact that the 2004 baseline included some 2005 data.

Table 4-2 2005 Emission Inventory (tons/yr)

\begin{tabular}{|c|c|c|c|c|c|c|c|c|c|c|c|c|}
\hline \multirow[t]{2}{*}{ Source } & \multicolumn{3}{|c|}{ ROG } & \multicolumn{3}{|c|}{$\mathrm{CO}$} & \multicolumn{3}{|c|}{ NOx } & \multicolumn{3}{|c|}{$\mathbf{P M}_{10}$} \\
\hline & Baseline & 2005 & Change & Baseline & 2005 & Change & Baseline & 2005 & Change & Baseline & 2005 & Change \\
\hline GSA & 0.05 & 0.03 & $-41 \%$ & 0.71 & 0.46 & $-34 \%$ & 0.32 & 0.18 & $-44 \%$ & 0.01 & 0.01 & $-26 \%$ \\
\hline Carts & 5.26 & 5.52 & $5 \%$ & 64.0 & 65.8 & $3 \%$ & 1.16 & 1.19 & $3 \%$ & 0.10 & 0.11 & $6 \%$ \\
\hline Landscaping & 6.54 & 6.72 & $3 \%$ & 15.65 & 16.0 & $2 \%$ & 0.33 & 0.33 & $0 \%$ & 0.257 & 0.264 & $3 \%$ \\
\hline Construction & 1.24 & 1.18 & $-4 \%$ & 14.3 & 13.8 & $-3 \%$ & 1.72 & 1.19 & $-31 \%$ & 0.12 & 0.10 & $-19 \%$ \\
\hline Total & 13.09 & 13.45 & $3 \%$ & 94.6 & 96.2 & $2 \%$ & 3.53 & 2.90 & $-18 \%$ & 0.49 & 0.48 & $-3 \%$ \\
\hline
\end{tabular}

Although the total percentage decreases or increases in ROG, $\mathrm{CO}$ and $\mathrm{PM}_{10}$ emissions may not be of significance, some observations and conclusions can be drawn from the relative numbers:

1. In order to significantly reduce ROG emissions, cart and landscaping usage (age of fleet, technology type, or hours used) must be affected.

2. Overall CO emissions can be most effectively reduced by influencing cart usage.

3. Overall $\mathrm{PM}_{10}$ emissions can be most effectively reduced by affecting landscaping equipment usage.

\section{Material Procurement and Use Objective: Procure and use environmentally friendly products and materials}

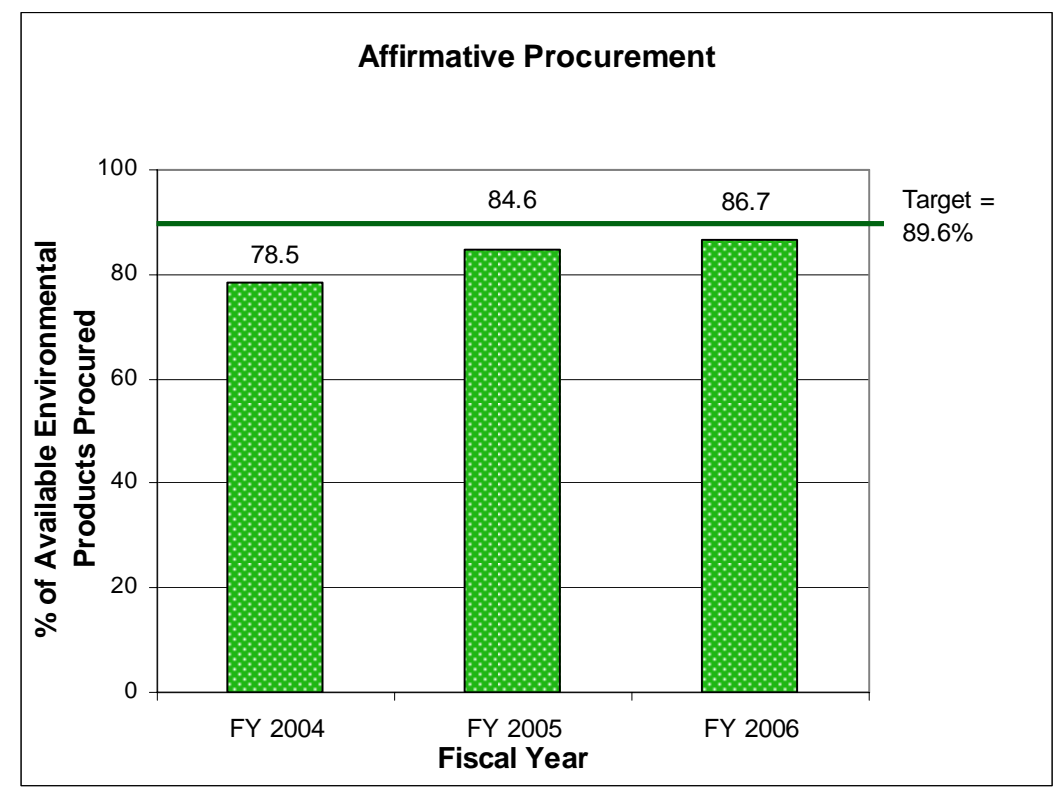

Figure 4-7 Procurement of Environmentally Friendly Products

SNL/CA's target for material procurement and use is to increase affirmative procurement in 2007 by ten percent over the fiscal year 2004/2005 average, from 81.5 to 89.6 percent of total 
available products procured. In 2006, Sandia achieved an increase of 6.4 percent in affirmative procurement and is well positioned to reach the ten percent target in 2007. The increase in fiscal year 2006 was due primarily to increases in recycled content paper, filing products, and furniture. During 2006, the Green Purchasing Team initiated efforts to review a variety of office product categories for procurement improvements that can be implemented in 2007. Additionally, SNL/CA will begin using bio-based products in 2007, which will also contribute to achieving our ten percent target.

\section{Land Use Objective: Enhance the natural habitat}

In June 2006, SNL/CA initiated an Arroyo Seco Improvement Program to address erosion and storm water control within the arroyo. The improvement program includes restoration of riparian habitat at select locations along the arroyo. SNL/CA restored approximately 0.05 acres of riparian habitat in 2006 by planting a variety of native trees and reseeding disturbed areas with native grasses. Plant survival and growth in restored areas and habitat use by bird species will be monitored annually to evaluate success of restoration efforts. Also in 2006, SNL/CA reseeded approximately two acres that burned during a grass fire with native grasses and wildflowers.

\section{Hazardous Materials Objective: Minimize the use of hazardous materials}

The overall goal of SNL/CA's EMS Program is protection of the environment from the negative effects of site activities including hazardous materials use. Central to this defense of the environment, is proper hazardous material inventory management. Right-sizing the inventory and minimizing toxicity is, therefore, key to environmentally friendly hazardous materials management, and was selected as an EMS target in 2006. SNL/CA has been using a barcoded container tracking system since 1993. Figure 4-8 suggests that amounts of hazardous materials, including the more toxic NFPA Health 3 and 4 rated materials, increased through the 1990's and peaked in 2002. A successful EMS goal-driven site wide campaign reduced the inventory by twelve percent in 2006 surpassing the five percent reduction goal. While SNL/CA accomplished significant progress in 2006, there is potential for additional reduction in future years to attain an inventory sized appropriately for site operations. 


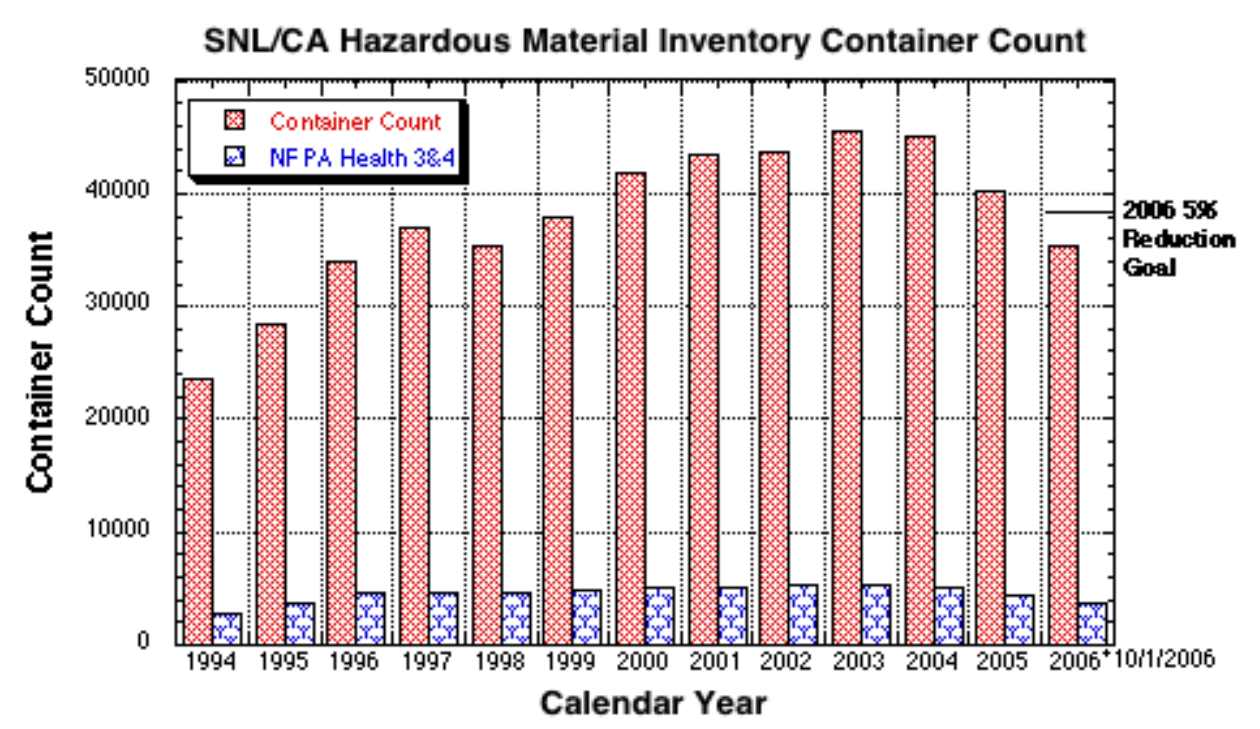

Figure 4-8 Quantity and Toxicity of Hazardous Materials at SNL/CA

\section{Radioactive and Hazardous Waste Objectives: Minimize the generation of radioactive and hazardous waste}

Although SNL/CA does not have a specific target for this objective, we strive to minimize generation of radioactive and hazardous waste through process controls, recycling, and reapplication of chemicals from one activity to another. Figures 4-9 and 4-10 show hazardous and radioactive waste generated since 2000, respectively. For both categories of waste, the trend shows a steady decline in quantities generated.

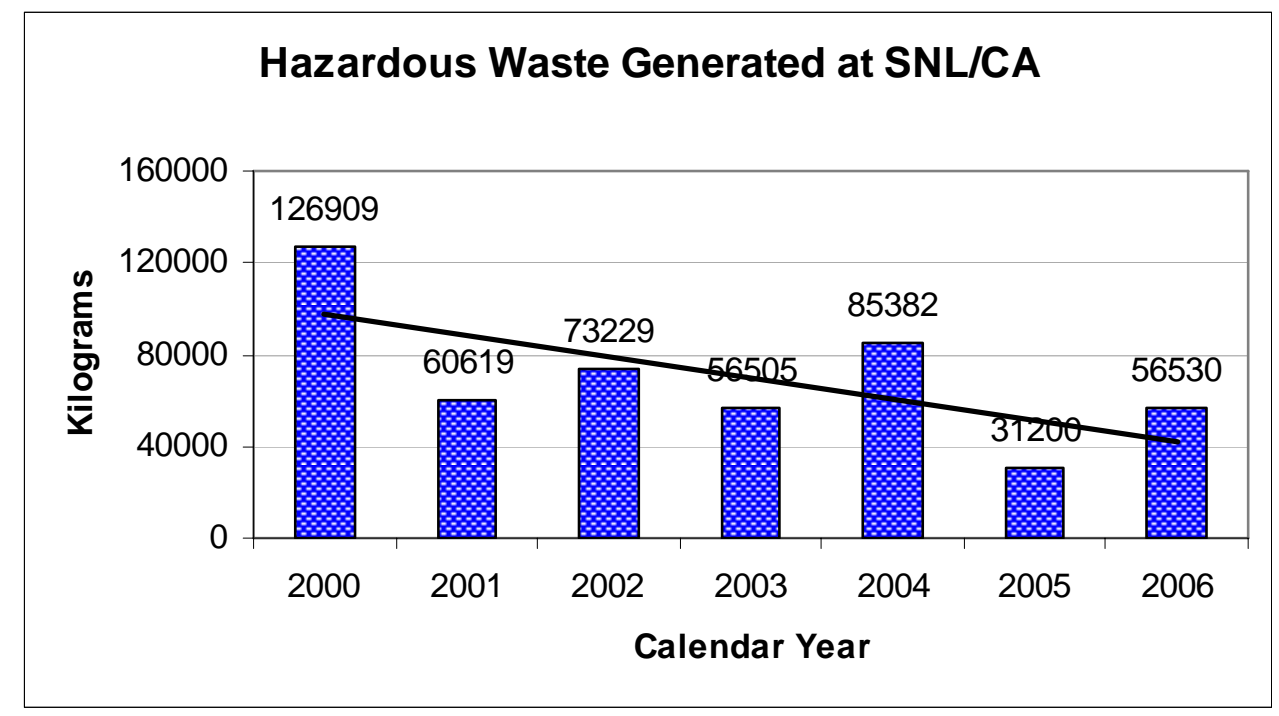

Figure 4-9 Hazardous Waste Generated at SNL/CA 


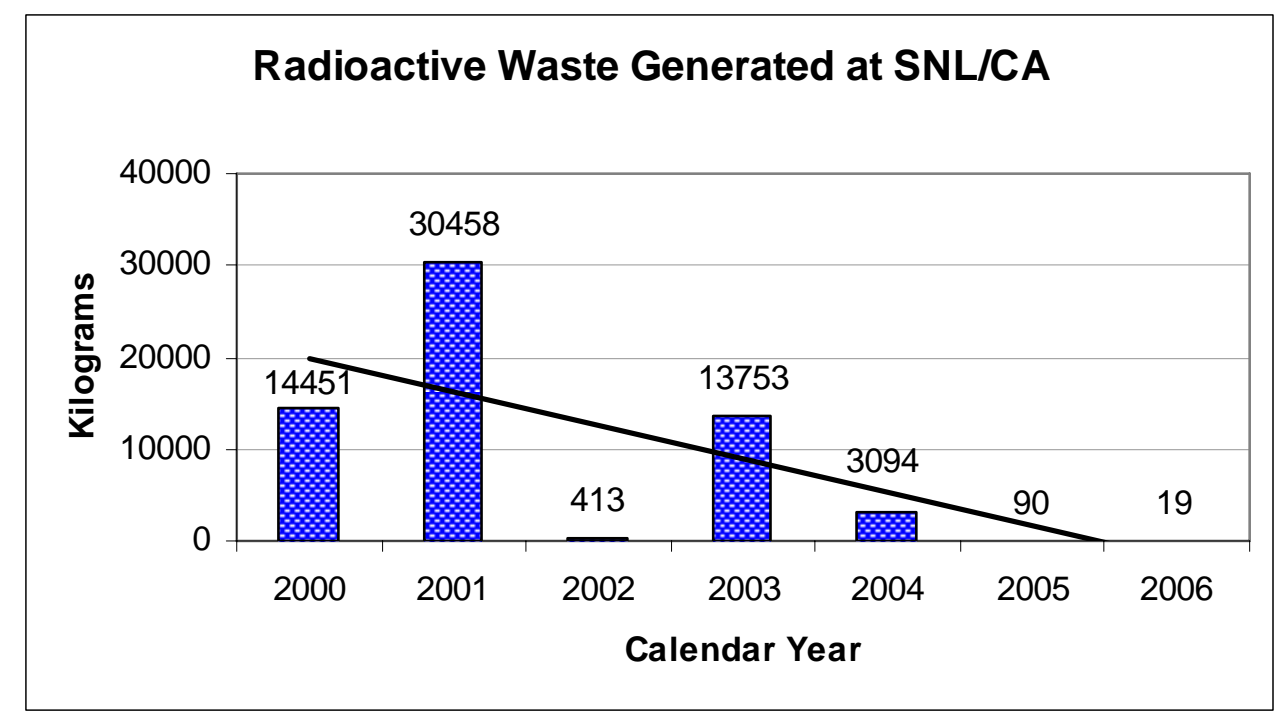

Figure 4-10 Radioactive Waste Generated at SNL/CA

\section{Asbestos Objective: Reduce site legacy asbestos material}

SNL/CA reduces site legacy asbestos material through routine abatement completed along with facility modification projects. In 2006, Sandia completed four asbestos abatement activities generating 354 kilograms of asbestos waste. Asbestos waste is a component of total hazardous waste presented in Figure 4-9.

\section{Solid Waste Objective: Minimize the quantity of landfill waste through reduced consumption and/or reuse/recycling}

SNL/CA transports non-hazardous solid waste (trash and construction debris) generated from site operations to local landfills for disposal. In fiscal year 2006, SNL/CA transported 137 metric tons of solid waste to landfills, a decrease of 28 metric tons from 2005. SNL/CA attributes the reduction in quantity of solid waste transported to landfills to the addition of four waste streams to the recycling program in 2006. Figure 4-11 presents solid waste data for fiscal years 2003 to 2006. Recycling data for most waste streams are presented in Figures 4-12 through 4-14. 


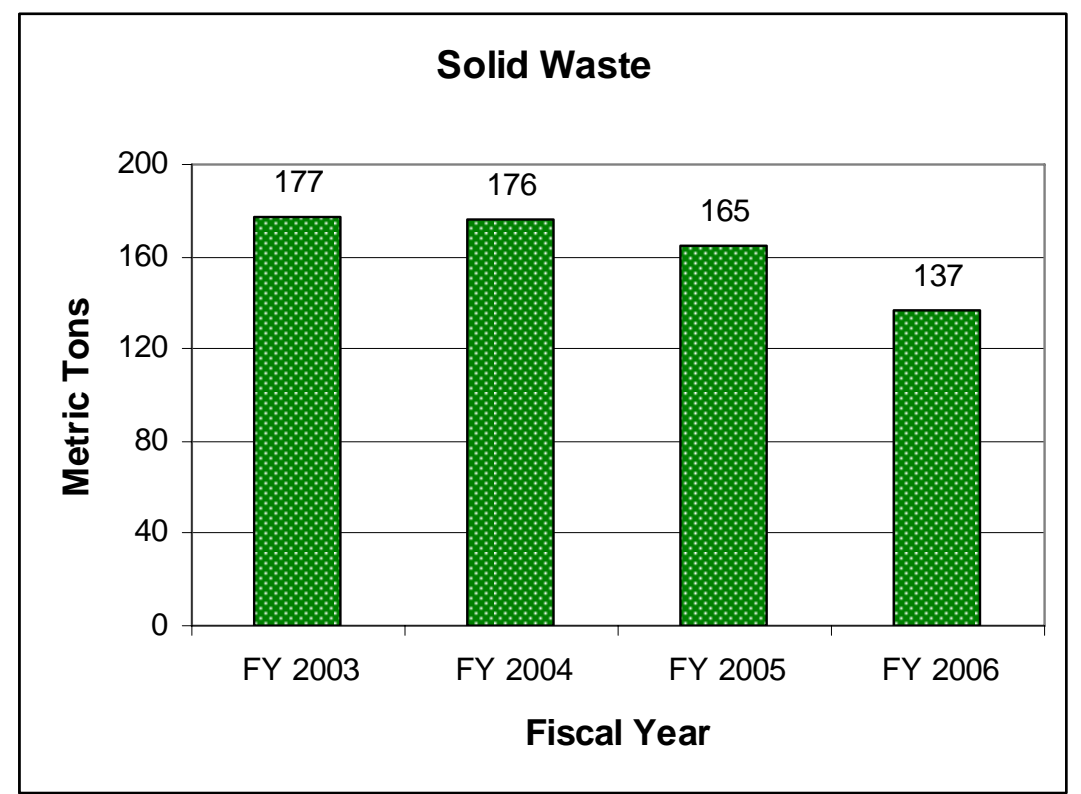

Figure 4-11 SNL/CA Landfill Waste

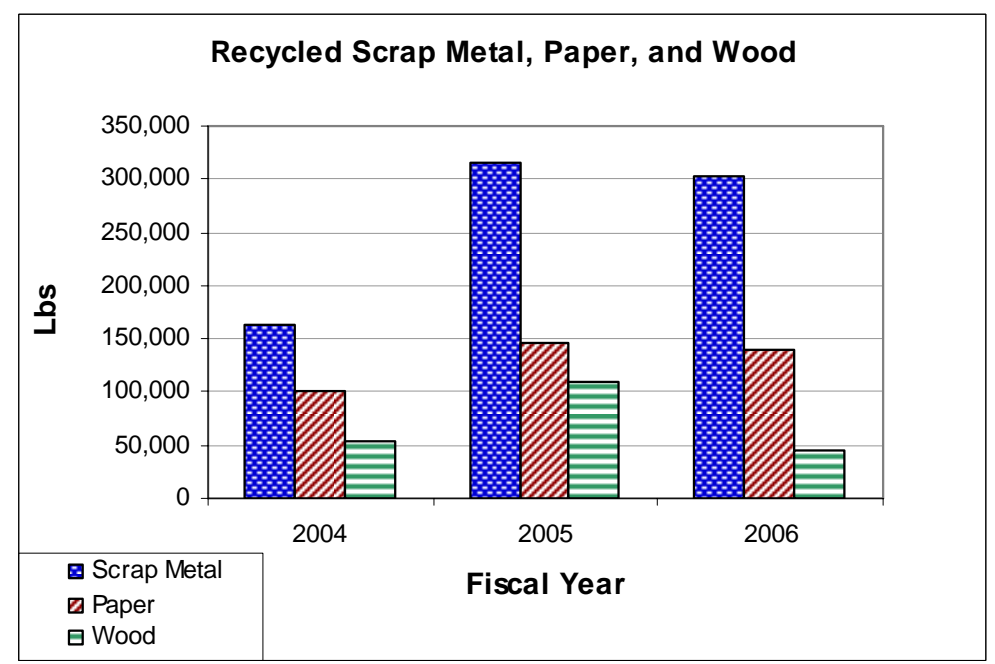

Figure 4-12 Recycled Scrap Metal, Paper, and Wood 


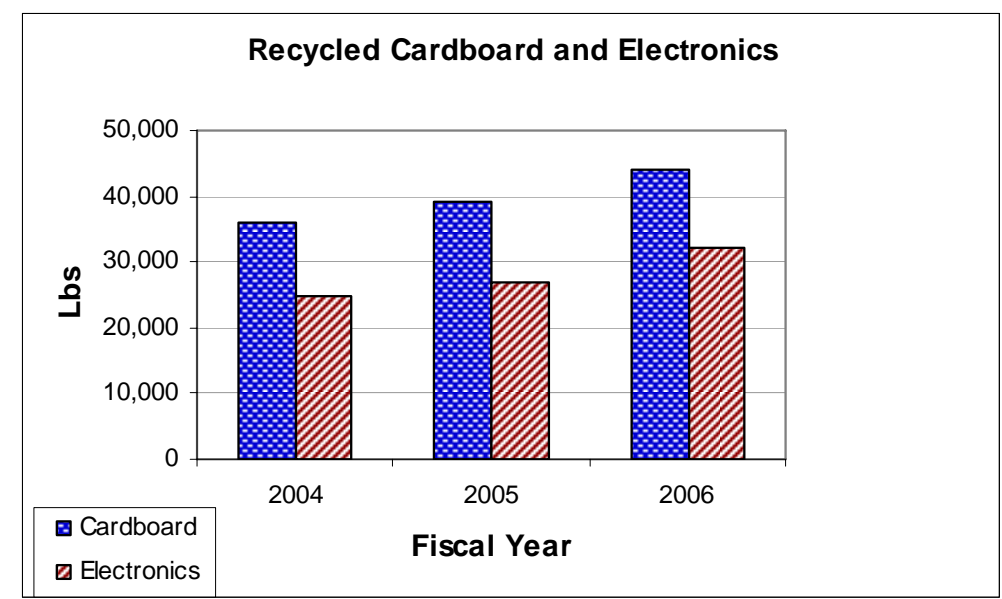

Figure 4-13 Recycled Cardboard and Electronics

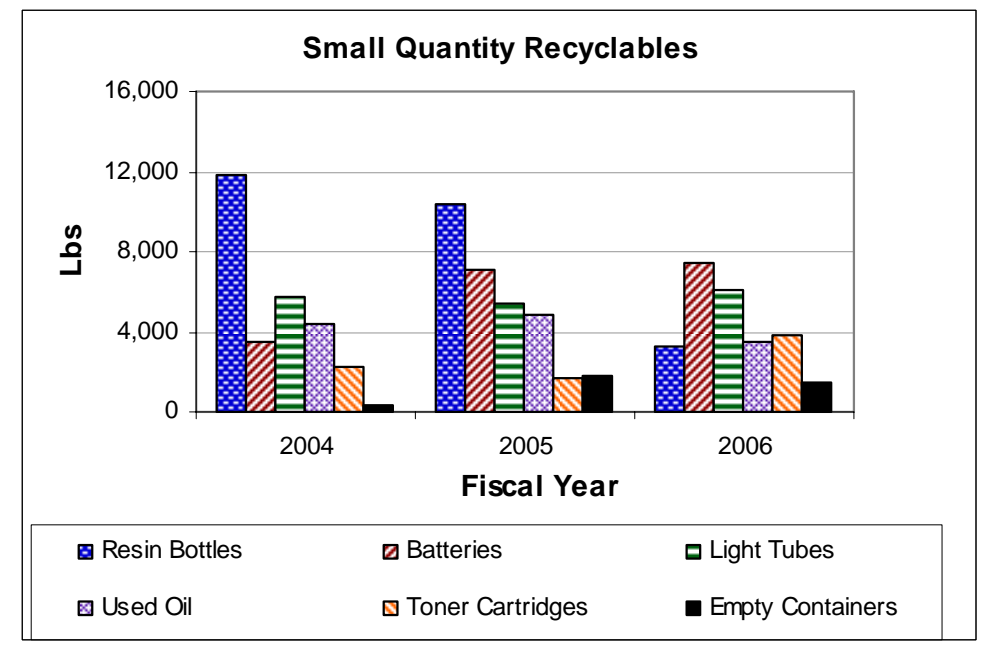

Figure 4-14 Small Quantity Recyclables

\section{Energy Use Objectives: Minimize site consumption of natural gas and electricity}

The Energy Policy Act of 2005 (HR 2005) establishes an energy reduction goal for federal agencies of two percent per year over a ten-year period starting in fiscal year 2006, using 2003 data as the baseline. Figure 4-15 displays SNL/CA's energy reduction target for 2006 through 2015. Data shows electricity and natural gas combined into British Thermal Units (BTUs). Between 2003 and 2006, SNL/CA reduced energy consumption by about seven percent, exceeding the established target for 2006 by five percent. SNL/CA attributes the reduction in energy consumption to two factors: 1) bringing two large facilities online that are energy efficient, and 2) a targeted energy conservation campaign. 


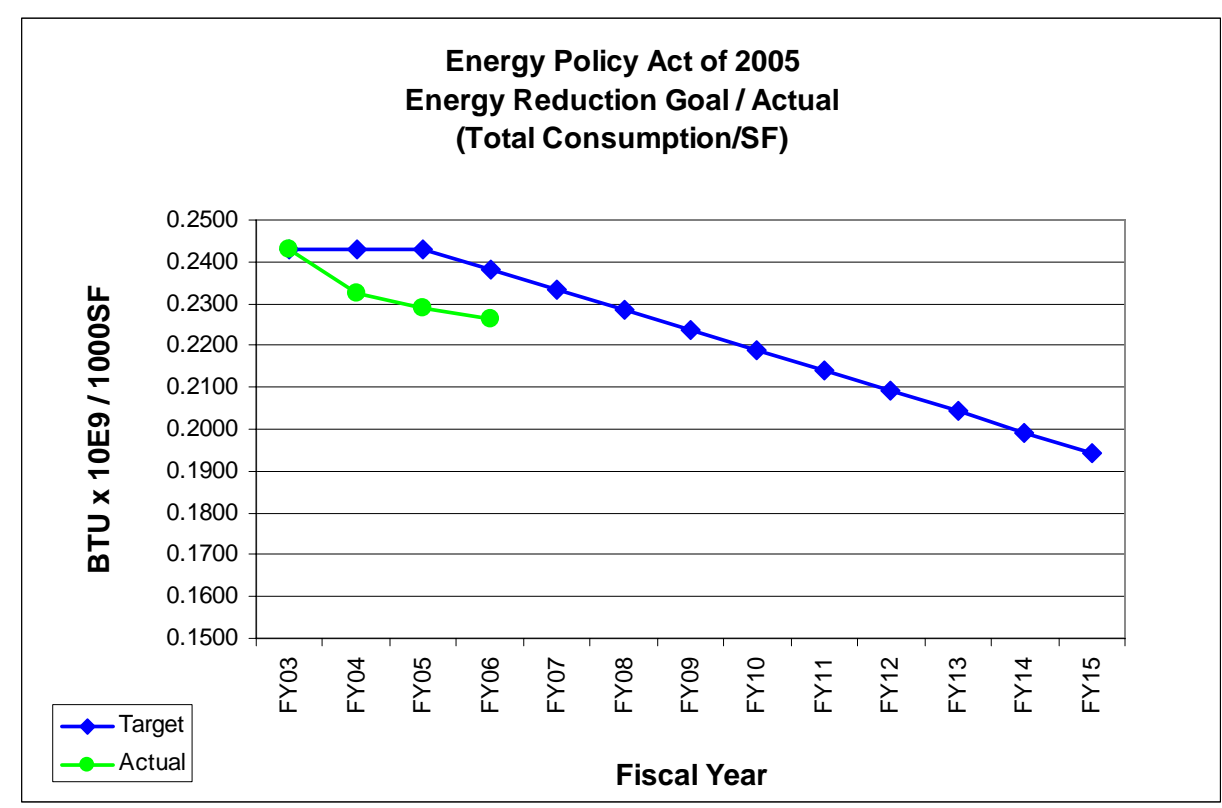

Figure 4-15 SNL/CA Energy Consumption

In fiscal year 2006, the National Nuclear Security Administration (NNSA) issued a one-year challenge to reduce overall energy consumption by ten percent at all NNSA facilities using 2004 as the baseline. Although SNL/CA implemented a targeted energy conservation campaign, the challenge was not met primarily because the site experienced a twelve percent increase in building square footage between 2004 and 2006. The increase in total energy use at SNL/CA in 2006 was 0.6 percent.

\section{Water Use Objective: Minimize site water consumption}

Figure 4-16 presents water use data for SNL/CA since 2001. As shown, the site has experienced an overall reduction in water use over the last six-years. The cause of the increase in 2006 is not known at this time. SNL/CA's water conservation efforts will continue through education and awareness of the site population, surveys for leaking fixtures, and modifications to and repair of fixtures. 


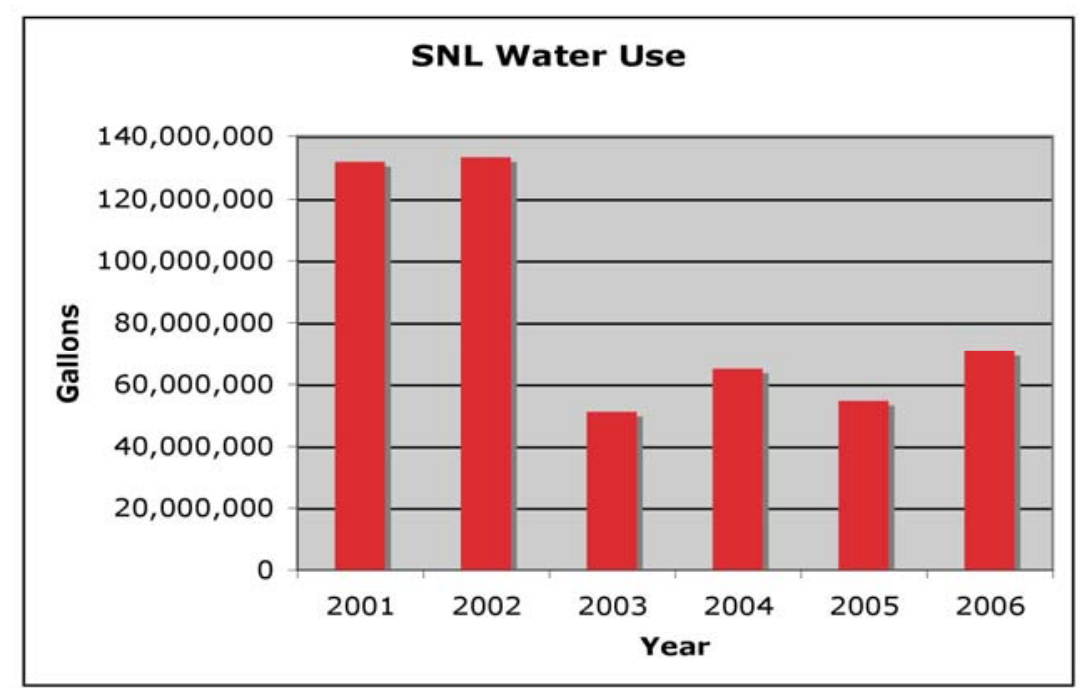

Figure 4-16 Water Consumption at SNL/CA

\subsection{Functional Environmental Program Highlights}

Six functional environmental programs support environmental management at SNL/CA, air quality, environmental monitoring and restoration, environmental planning and ecology, hazardous materials management, pollution prevention and waste minimization, and waste management. The following sections summarize the responsibilities of each program and identify the highlights that occurred during 2006.

\subsubsection{Air Quality Program}

The Air Quality Program provides compliance assistance for all nonradiological air emission sources at SNL/CA. Program staff review all directives, laws, and regulations relevant to air emissions for applicability to the site. This program manages the air permit process, from the initial steps of preparing permit applications through implementation of permit conditions and annual renewals. The Air Quality Program is responsible for evaluating proposed projects, assessing chemical use, and assessing emissions of all criteria pollutants and toxic air contaminants.

In 2006, Sandia's painting operations reduced volatile organic compound (VOC) emissions as a result of Air Quality Program actions completed in 2005. In 2005, the Air Quality Program was instrumental in acquiring the following two new pieces of cleaning equipment for Sandia's painting operations. This new equipment and the resulting process changes not only reduce the VOC emissions to the atmosphere, but also reduce the risk of violating the strict regulations governing the use of solvents.

A new paint-gun cleaner provides a closed-loop cleaning process for the spray guns. Although this equipment still uses a solvent for cleaning, the closed-loop design greatly decreases the VOC emissions compared to the hand cleaning process previously employed. A total of 0.25 gallons of solvent evaporated from the use of the 
gun cleaner in 2006, compared to ten gallons evaporating from the gun cleaning process in 2004.

> A parts wash rack uses hot pressurized water to clean metal parts prior to painting. This piece of equipment replaces a hand-cleaning method that used high VOC solvents. A total of 1.5 gallons of solvent were used for wipe cleaning / surface preparation tasks in 2006, compared to 6.75 gallons evaporated in 2004.

\subsubsection{Environmental Monitoring and Restoration Program}

The Environmental Monitoring and Restoration Program routinely monitors wastewater, storm water, and groundwater systems at SNL/CA to assess the affect of site operations on the public and local environment. Monitoring of external radiation at the site perimeter is also conducted under this program. Routine monitoring activities and results are presented in Chapter 5.

During 2006, the Environmental Monitoring and Restoration Program implemented several equipment upgrades. Satellite sewer samplers were converted from battery to solar power, storm water flow monitors were installed in the Arroyo Seco, and aging equipment was replaced at several liquid effluent control systems.

\subsubsection{Environmental Planning and Ecology Program}

The Environmental Planning and Ecology Program provides oversight for ecological resource management, site-wide National Environmental Policy Act (NEPA) review, and cultural and historic resource reviews. Each year, the Environmental Planning and Ecology Program compares actual site operations to the maximum operations scenario presented in a site-wide environmental assessment (SWEA) to determine whether SNL/CA operations remain within the bounding impact analysis. Table 4-3 presents a summary of the comparison and an evaluation of the results. 
Table 4-3 Comparison of 2006 Operations with SWEA Envelope

\begin{tabular}{|c|c|c|c|}
\hline Activity / Unit & $\begin{array}{l}\text { SWEA Envelope (maximum } \\
\text { operations) }\end{array}$ & Calendar Year 2006 & $\begin{array}{l}\text { Site Operations Remain } \\
\text { Within Impact Analysis } \\
\end{array}$ \\
\hline \multicolumn{4}{|l|}{ Proposed Action } \\
\hline Site mission & Supports DOE, NNSA, DHS & No change & Yes \\
\hline $\begin{array}{l}\text { Arroyo Seco } \\
\text { improvements }\end{array}$ & 20 tasks over ten years & 5 tasks completed & Yes \\
\hline Increase operations & Increase to 2 shifts & 1 shift & Yes \\
\hline New facilities & $\begin{array}{l}\text { 5,000 sf badge office; new } \\
16,000 \text { sf laboratory; } 84,000 \text { sf } \\
\text { laboratory replacement for } \\
\text { Building } 916\end{array}$ & $\begin{array}{l}\text { A } 500 \text { sf trailer installed } \\
\text { as badge office at East } \\
\text { Ave entrance }\end{array}$ & Yes \\
\hline Demolition & 100,000 sf over ten years & $\begin{array}{l}1,656 \mathrm{sf} \text { as of December } \\
31,2006\end{array}$ & Yes \\
\hline \multicolumn{4}{|l|}{ Land Use } \\
\hline Construction area & 93 acres over ten years & $\begin{array}{l}8 \text { acres as of December } \\
31,2006\end{array}$ & Yes \\
\hline Wildlife reserve & 30 acres over ten years & 106 acres & $\begin{array}{l}\text { Yes - results in a positive } \\
\text { effect }\end{array}$ \\
\hline \multicolumn{4}{|l|}{ Geology / Soil } \\
\hline $\begin{array}{l}\text { Solid waste } \\
\text { management units }\end{array}$ & 23 units total & 22 units & Yes \\
\hline Soil removed & $5000 \mathrm{cu} \mathrm{yd} / \mathrm{yr}$ & 0 cu yd & Yes \\
\hline Soil managed onsite & $5000 \mathrm{cu} \mathrm{yd} / \mathrm{yr}$ & 1200 cu yd & Yes \\
\hline $\begin{array}{l}\text { Backfill material } \\
\text { brought onsite }\end{array}$ & $6000 \mathrm{cu} \mathrm{yd} / \mathrm{yr}$ & $500 \mathrm{cu}$ yd & Yes \\
\hline \multicolumn{4}{|l|}{ Infrastructure } \\
\hline Water use & $91.8 \mathrm{million} \mathrm{gal} / \mathrm{yr}$ & 70.7 million gals & Yes \\
\hline $\begin{array}{l}\text { Sanitary sewer } \\
\text { discharge }\end{array}$ & $29.1 \mathrm{million}$ gal $/ \mathrm{yr}$ & 11.2 million gals & Yes \\
\hline Natural gas use & 94 million cu ft/yr & 72.2 million $\mathrm{cu} \mathrm{ft}^{\mathrm{e}}$ & Yes \\
\hline Electricity use & $48,800 \mathrm{MW} \mathrm{h} / \mathrm{yr}$ & 35,928.8 MW hrs ${ }^{\mathrm{e}}$ & Yes \\
\hline \multicolumn{4}{|l|}{$\begin{array}{l}\text { Biological and Ecological } \\
\text { Resources }\end{array}$} \\
\hline $\begin{array}{l}\text { Construct flood plains } \\
\text { in Arroyo Seco }\end{array}$ & 1800 linear feet over ten years & None & Yes \\
\hline Create riparian habitat & 0.2 acres over ten years & $\begin{array}{l}0.05 \text { acres as of } \\
\text { December 31. } 2006\end{array}$ & Yes \\
\hline $\begin{array}{l}\text { Ground disturbance in / } \\
\text { along arroyo }\end{array}$ & 10 acres over ten years & $\begin{array}{l}<3 \text { acres as of } \\
\text { December 31, } 2006\end{array}$ & Yes \\
\hline Cultural Resources & None known onsite & No change & Yes \\
\hline \multicolumn{4}{|l|}{ Water Resources } \\
\hline Impervious surface area & 76.9 acres total & 54.3 acres & Yes \\
\hline Irrigation water use & 17 million gal/yr & 16.6 million gals & Yes \\
\hline \multicolumn{4}{|l|}{ Waste Generation } \\
\hline Radioactive waste & $8,811 \mathrm{~kg} / \mathrm{yr}$ & $19 \mathrm{~kg}$ & Yes \\
\hline Hazardous waste & $133,820 \mathrm{~kg} / \mathrm{yr}$ & $56,530 \mathrm{~kg}$ & Yes \\
\hline $\begin{array}{l}\text { Construction debris } \\
\text { (sub-set of solid waste) }\end{array}$ & 200 tons/yr & $\begin{array}{l}259 \text { metric } \text { tons }^{\mathrm{e}}- \\
\text { recycled } \\
16.5 \text { metric tons }{ }^{\mathrm{e}}- \\
\text { waste }\end{array}$ & Yes \\
\hline $\begin{array}{l}\text { Solid waste (non- } \\
\text { hazardous, excludes } \\
\text { construction debris) }\end{array}$ & 378.7 metric tons/yr & 120.5 metric tons $^{\mathrm{e}}$ & Yes \\
\hline
\end{tabular}




\begin{tabular}{|c|c|c|c|}
\hline Activity / Unit & $\begin{array}{l}\text { SWEA Envelope (maximum } \\
\text { operations) }\end{array}$ & Calendar Year 2006 & $\begin{array}{l}\text { Site Operations Remain } \\
\text { Within Impact Analysis }\end{array}$ \\
\hline \multicolumn{4}{|l|}{ Proposed Action } \\
\hline \multicolumn{4}{|l|}{ Transportation } \\
\hline $\begin{array}{l}\text { Hazardous / radioactive } \\
\text { waste shipments }\end{array}$ & 116 shipments/yr & 22 shipments & Yes \\
\hline $\begin{array}{l}\text { Non-hazardous waste } \\
\text { shipments (solid waste and } \\
\text { construction debris) }\end{array}$ & 80 shipments/yr & 26 shipments & Yes \\
\hline \multicolumn{4}{|l|}{ Air Emissions } \\
\hline Total criteria pollutants & $8,212 \mathrm{~kg} / \mathrm{yr}$ & $6,525 \mathrm{~kg}^{\mathrm{a}}$ & Yes \\
\hline Total air toxics & $2,880.16 \mathrm{~kg} / \mathrm{yr}$ & $2,500 \mathrm{~kg}^{\mathrm{a}}$ & Yes \\
\hline Radioactive & 0 emissions & 0 emissions & Yes \\
\hline Permits & 57 permits annually & $15 / 15$ permits $^{b}$ & Yes \\
\hline \multicolumn{4}{|l|}{ Human Health } \\
\hline $\begin{array}{l}\text { Recordable accidents / } \\
\text { injuries }\end{array}$ & 78 accidents / injuries annually & 21 accident / injuries & Yes \\
\hline Lost work-day cases & 19 days annually ${ }^{\mathrm{c}}$ & 11 days & Yes \\
\hline \multicolumn{4}{|l|}{ Socioeconomics } \\
\hline Employment & Up to 1931 persons annually & 1040 persons $^{\mathrm{d}}$ & Yes \\
\hline Operating budget & $\$ 262$ million/yr & 220 million $^{\mathrm{e}}$ & Yes \\
\hline \multicolumn{4}{|c|}{$\begin{array}{l}\text { Annual emissions were calculated by multiplying the daily emissions reported in the BAAQMD Permit tc } \\
\text { Emissions are based on } 2005 \text { data. } \\
\text { b Data provided for the } 2005 / 2006 \text { and 2006/2007 permit periods. See Section } 3.3 .1 \text { for more information. } \\
\text { c Extrapolated from historical average. } \\
\text { d Sandia employees only. Does not include contract staff. Data from September } 2006 \text {. } \\
\text { e Fiscal year data (October 1, } 2005 \text { - September 30, 2006). }\end{array}$} \\
\hline
\end{tabular}

\subsubsection{Hazardous Materials Management Program}

The Hazardous Materials Management Program is responsible for tracking hazardous materials (chemical and biological), managing the Material Safety Data Sheet (MSDS) library, providing MSDS information to site personnel, and for regulatory compliance reporting required under various hazardous materials regulations.

Each year, the Hazardous Materials Management Program conducts annual hazardous material inventory reconciliation. In 2006, the reconciliation team achieved a 93 percent found rate, the highest achieved rate since annual reconciliations began over ten years ago. This result surpasses by three percent the corporate performance target of 90 percent.

A successful EMS goal driven site-wide campaign reduced the hazardous material inventory by twelve percent (by container count) in 2006 surpassing the five percent reduction goal (see Section 4.1). The redesigned Chemical Information System implemented in December 2004 aided this success greatly. New inventory management tools developed in the system were refined throughout 2006 providing information critical to the success of the inventory reduction campaign.

\subsubsection{Pollution Prevention and Waste Minimization Program}

The Pollution Prevention and Waste Minimization Program promotes the elimination or reduction of all waste types generated at SNL/CA. Program staff work closely with other SNL/CA organizations to establish routine and project-specific recycling programs. The program provides guidance for resource and energy conservation and assists in identifying 
recycled-content products for use throughout the site. See Section 4.1 for recycling and waste minimization data.

During 2006, SNL/CA implemented improvements to reduce waste generated from several site operations. Sandia removed 4,828 pounds of lead slag from the on-site firing range during a renovation project. The lead slag was shipped offsite for recycling at a cost savings of \$61,300 estimated for hazardous waste disposal fees. The Pollution Prevention and Waste Minimization Program was instrumental in reapplying 90 containers of chemicals and eight pallets of plating supplies that became available for alternate uses when a plating laboratory closed. Program staff also implemented processes to recycle four new waste streams: glass and plastic beverage containers, pipette boxes, and wood pallets.

\subsubsection{Waste Management Program}

The Waste Management Program manages hazardous, radioactive, and mixed wastes generated by SNL/CA operations. Program personnel collect waste from the point of generation and transfer waste to onsite waste storage facilities for storage, consolidation, commingling, and packaging. The Waste Management Program establishes and maintains several contracts for offsite reclamation, recycling, treatment, and disposal of wastes. Waste Management provides regulatory oversight in accordance with federal, state, and local regulations. The Program manages the Resource Conservation and Recovery Act (RCRA) and Tiered permit process, and implements RCRA and Tiered permit conditions. Program staff conduct process knowledge evaluations to characterize waste types generated from specific operations. The Waste Management Program also provides waste generator training to the Sandia workforce.

In 2006, Waste Management revised its Hazardous Waste Operation Plan to reflect current administrative conditions, to update processes, and to correct informational and typographical errors. SNL/CA also continued the process of transferring management of radioactive waste to SNL New Mexico, which is expected to be completed by winter 2007. Radioactive waste generated at SNL/CA will continue to be tracked locally and reported in the site annual reports. Waste Management supported the site-wide campaign for chemical inventory reduction and continued its efforts to minimize routine hazardous waste generation at SNL/CA. 


\section{Environmental Monitoring}

Sandia National Laboratories, California (SNL/CA) monitors storm water, wastewater, groundwater, and gamma radiation. This chapter provides a summary of monitoring activities and results for each of these media. Both radiological and non-radiological data are presented.

SNL/CA does not directly monitor airborne effluents. Non-radiological (chemical) emission sources do not require routine or continuous monitoring of ambient air quality concentrations. However, SNL/CA does maintain equipment and process usage records (e.g. hours of operation or quantity of solvents used) for emission sources. Similarly, there are no radionuclide emission sources that require routine monitoring. SNL/CA maintains an inventory of radioactive isotopes (small quantity sealed and unsealed sources), and operates several radiation generating devices. Emission monitoring is not required for these materials and devices.

Typically, radiological emission data that would be obtained from radionuclide effluent monitoring is used to evaluate the potential effect that a particular site's operations may have on local populations and the environment. Because there are no radionuclide emission sources and no monitoring data for site operations, calculations for maximum individual dose or collective population dose are not possible. As an alternative to these calculations, SNL/CA compares gamma radiation data collected at the site perimeter to offsite data. Results of this comparison are presented in Section 5.4.

SNL/CA is not required to monitor biota or vegetation. The Department of Energy (DOE) RAD-BCG Calculator, a computer tool developed by DOE, is used each year to determine the need and level of monitoring required. The results from applying the tool in 2006 are presented in Section 5.4 .

\subsection{Storm Water}

All storm water runoff from SNL/CA is conveyed to the Arroyo Seco, which discharges into Alameda Creek and eventually to the San Francisco Bay. Storm water that flows off buildings, material-handling areas, parking lots, and other impervious surfaces, may pick up pollutants, such as oil and grease, soil, litter, pesticides, and fertilizers. During heavy or continuing storms, runoff may transport pollutants to Arroyo Seco before the storm water has time to evaporate or infiltrate into the ground.

To assess the impact of site operations to storm water discharges, SNL/CA collects samples of surface runoff at nine locations around the site. These locations, identified on Figure 5-1, were selected because they provide the best representation of drainage areas and activities onsite. Each of the nine locations is sampled twice each wet season, once each during two 


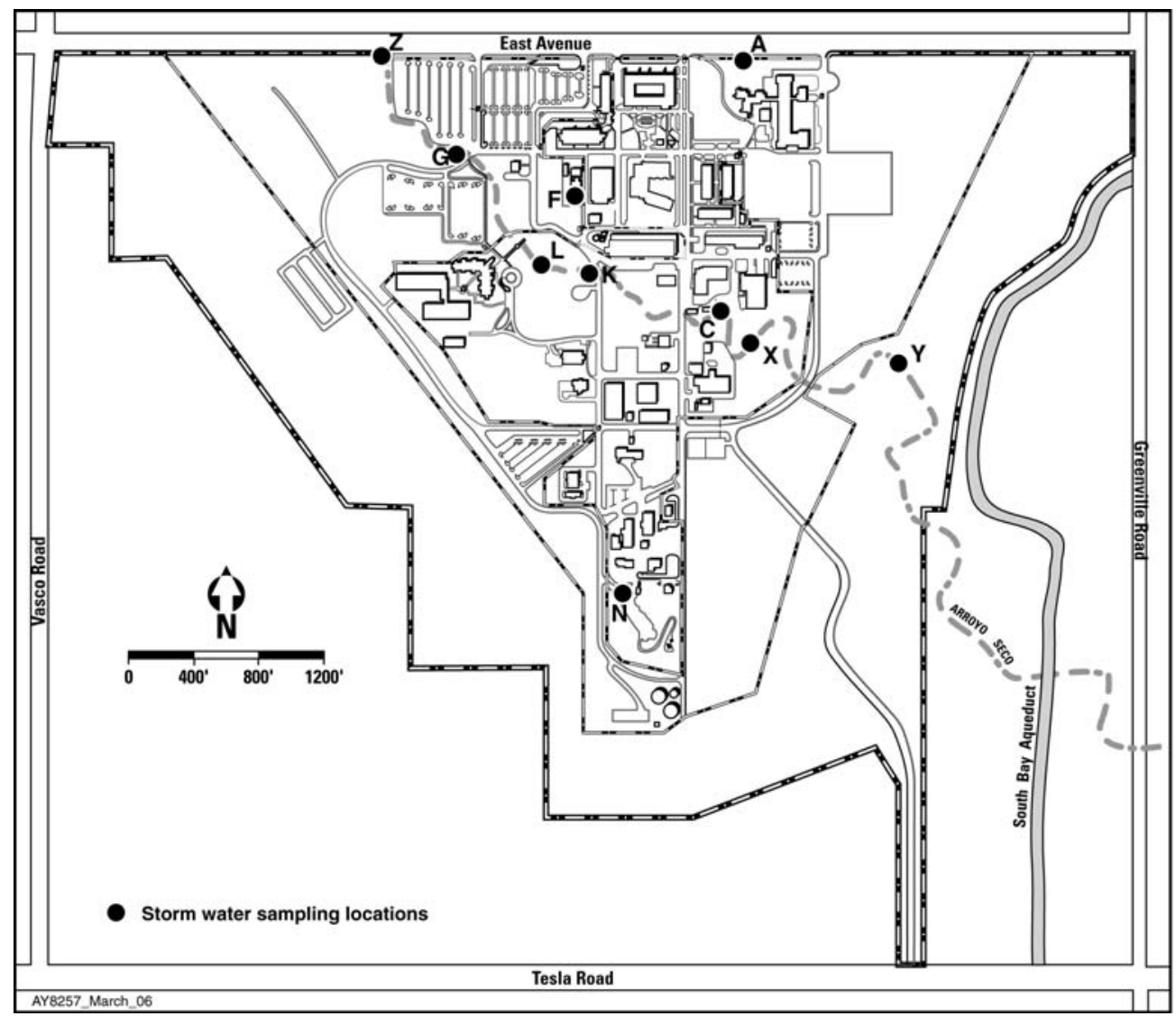

Figure 5-1 Storm Water Sampling Locations

separate storm events, provided there is sufficient runoff. The wet season is from October 1 through May 31. Because any one storm may not produce enough runoff to allow for sample collection at all nine locations, sampling during more than two storm events is generally required.

One additional sampling location, Station N, is used to monitor erosion from the Navy Landfill, but is not sampled for the storm water program. During the 2005/2006 rainy season, Station $\mathrm{N}$ was not sampled due to insufficient runoff.

Storm water discharges at SNL/CA are covered under the State of California NPDES General Permit for Storm Water Discharge Associated with Industrial Activities (General Permit) (California Water Resources Control Board 1997). The General Permit does not establish water quality standards for storm water discharges. Consequently, a comparison of analytical results with regulatory standards cannot be made. Instead, the analytical data obtained from monitoring storm water discharge is used to optimize storm water pollution prevention activities at SNL/CA.

\begin{tabular}{|ll|}
\hline & Analytical Parameters - Stormwater \\
$>$ & Specific conductivity \\
$>$ & $\mathrm{pH}$ \\
$>$ & Total suspended solids \\
$>$ & Oil and grease \\
$>$ & Cyanide \\
$>$ & Chetals \\
$>$ & Nitrite + nitrate \\
$>$ & Ammonia \\
$>$ & Tritium \\
\hline
\end{tabular}


Analytical results of storm water sampling for the 2005/2006 wet season (October 2005 through May 2006) are presented in Table 5-1. No pollutants were detected in storm water runoff at levels that are a cause for concern. The concentrations of constituents detected in storm water are similar to those detected historically.

Table 5-1 Summary of Analytical Results for Storm Water, 2005/2006 Wet Season

\begin{tabular}{|c|c|c|c|c|c|}
\hline Parameter & $\begin{array}{l}\text { Number of } \\
\text { Samples } \\
\text { Analyzed }\end{array}$ & $\begin{array}{l}\text { Number Found } \\
\text { Below Detection } \\
\text { Limit }\end{array}$ & Detection Limit & $\begin{array}{l}\text { Minimum } \\
\text { Concentration }\end{array}$ & $\begin{array}{l}\text { Maximum } \\
\text { Concentration }\end{array}$ \\
\hline Total suspended solids & 16 & 0 & $3 \mathrm{mg} / \mathrm{L}$ & $7 \mathrm{mg} / \mathrm{L}$ & $160 \mathrm{mg} / \mathrm{L}$ \\
\hline Specific conductivity & 16 & 0 & $1 \mu \mathrm{mho} / \mathrm{cm}$ & $22 \mu \mathrm{mho} / \mathrm{cm}$ & $1900 \mu \mathrm{mho} / \mathrm{cm}$ \\
\hline $\mathrm{pH}$ & 16 & 0 & None & 6.2 & 8.2 \\
\hline Oil and grease & 16 & 6 & $1 \mathrm{mg} / \mathrm{L}$ & $<1.0 \mathrm{mg} / \mathrm{L}$ & $3.1 \mathrm{mg} / \mathrm{L}$ \\
\hline $\begin{array}{l}\text { Chemical oxygen } \\
\text { demand }\end{array}$ & 16 & 0 & $5 \mathrm{mg} / \mathrm{L}$ & $26 \mathrm{mg} / \mathrm{L}$ & $120 \mathrm{mg} / \mathrm{L}$ \\
\hline Cyanide & 16 & 16 & $0.01 \mathrm{mg} / \mathrm{L}$ & $<0.01 \mathrm{mg} / \mathrm{L}$ & $<0.01 \mathrm{mg} / \mathrm{L}$ \\
\hline Tritium & 16 & 16 & $\begin{array}{l}1.45-1.53 \\
\mathrm{pCi} / \mathrm{L}\end{array}$ & $<1.45 \mathrm{pCi} / \mathrm{L}$ & $<1.53 \mathrm{pCi} / \mathrm{L}$ \\
\hline Aluminum & 16 & 0 & $0.05 \mathrm{mg} / \mathrm{L}$ & $0.15 \mathrm{mg} / \mathrm{L}$ & $5.1 \mathrm{mg} / \mathrm{L}$ \\
\hline Arsenic & 16 & 15 & $0.002 \mathrm{mg} / \mathrm{L}$ & $<0.002 \mathrm{mg} / \mathrm{L}$ & $0.003 \mathrm{mg} / \mathrm{L}$ \\
\hline Cadmium & 16 & 16 & $\begin{array}{l}0.002-0.01 \\
\mathrm{mg} / \mathrm{L}\end{array}$ & $<0.002 \mathrm{mg} / \mathrm{L}$ & $<0.01 \mathrm{mg} / \mathrm{L}$ \\
\hline Iron & 16 & 0 & $0.05 \mathrm{mg} / \mathrm{L}$ & $0.20 \mathrm{mg} / \mathrm{L}$ & $8.2 \mathrm{mg} / \mathrm{L}$ \\
\hline Lead & 16 & 12 & $0.005 \mathrm{mg} / \mathrm{L}$ & $<0.005 \mathrm{mg} / \mathrm{L}$ & $0.077 \mathrm{mg} / \mathrm{L}$ \\
\hline Magnesium & 11 & 0 & $0.10 \mathrm{mg} / \mathrm{L}$ & $0.73 \mathrm{mg} / \mathrm{L}$ & $66 \mathrm{mg} / \mathrm{L}$ \\
\hline Mercury & 16 & 16 & $\begin{array}{l}0.0002-0.0004 \\
\mathrm{mg} / \mathrm{L}\end{array}$ & $<0.0002 \mathrm{mg} / \mathrm{L}$ & $0.0004 \mathrm{mg} / \mathrm{L}$ \\
\hline Selenium & 16 & 16 & $0.002 \mathrm{mg} / \mathrm{L}$ & $<0.002 \mathrm{mg} / \mathrm{L}$ & $0.002 \mathrm{mg} / \mathrm{L}$ \\
\hline Silver & 16 & 16 & $\begin{array}{l}0.005-0.01 \\
\mathrm{mg} / \mathrm{L}\end{array}$ & $<0.005 \mathrm{mg} / \mathrm{L}$ & $<0.01 \mathrm{mg} / \mathrm{L}$ \\
\hline Zinc & 16 & 1 & $0.02 \mathrm{mg} / \mathrm{L}$ & $<0.02 \mathrm{mg} / \mathrm{L}$ & $0.38 \mathrm{mg} / \mathrm{L}$ \\
\hline Ammonia-N & 16 & 11 & $0.5-1 \mathrm{mg} / \mathrm{L}$ & $<0.5 \mathrm{mg} / \mathrm{L}$ & $<1 \mathrm{mg} / \mathrm{L}$ \\
\hline Nitrite + nitrate & 16 & $1 / 12$ & $1.0 / 0.05 \mathrm{mg} / \mathrm{L}$ & $<1.0 /<0.05 \mathrm{mg} / \mathrm{L}$ & $10 / 0.15 \mathrm{mg} / \mathrm{L}$ \\
\hline
\end{tabular}

Annually, SNL/CA evaluates storm water pollution prevention practices at each drainage location as part of its monitoring activities. No discharges of unauthorized storm water were found during the annual site inspection.

During years of sufficient runoff, SNL/CA compares the analytical results from storm water entering the site to storm water exiting the site. In 2006, the following parameter concentrations were higher leaving the site than entering the site: aluminum, ammonia, chemical oxygen demand, iron, total suspended solids (one sample), and zinc. Although some of the constituent concentrations were higher leaving the site than entering the site, these concentrations are not considered elevated. The following parameter concentrations were lower leaving the site than entering the site: nitrate (one sample), nitrite, magnesium, and specific conductance. One sample from location $\mathrm{X}$ was uncharacteristically high in total suspended solids, oil and grease, specific conductance, and some metals. Construction 
activities in the area may have contributed to the higher than normal concentrations at this location.

\subsection{Wastewater}

Wastewater effluent generated at SNL/CA consists of sanitary and laboratory discharges. Sanitary effluent is discharged directly to the sewer system. Sewer discharges exit the site through a sewer outfall located at the northern boundary, and join with the Lawrence Livermore National Laboratory (LLNL) sewer system. Laboratory discharges are generated from general research activities, and from operations that qualify as categorical processes subject to Federal pretreatment standards. Laboratory effluent from most laboratory areas is diverted to liquid effluent control system (LECS) holding tanks prior to discharge to the sanitary sewer. SNL/CA monitors wastewater at the sewer outfall, LECS tanks, and at categorical process point sources.

\subsubsection{Sewer Outfall}

SNL/CA operates a sewer outfall and monitoring station at the northern site boundary to continuously monitor wastewater for flow and $\mathrm{pH}$. Samples are also collected at the outfall to monitor compliance with wastewater discharge limits established in the site's Wastewater Discharge Permit. The outfall sampling schedule and analytical parameters are presented in Table 5-2. Consistent with permit requirements, SNL/CA does not analyze wastewater samples collected at the sewer outfall for radioactive constituents.

Table 5-2 Sewer Outfall Sampling Schedule, 2006

\begin{tabular}{lll}
\hline Frequency & Sample Type & Analytical Parameter \\
\hline Daily & Composite & $\begin{array}{l}\text { Archive sample; analyzed only } \\
\text { when weekly composite sample } \\
\text { shows concentration greater than or } \\
\text { equal to 50\% of discharge limit for } \\
\text { metals. }\end{array}$ \\
\hline Weekly & & Metals \\
\hline Monthly & Composite & Total dissolved solids \\
& Composite & Total suspended solids \\
& & Biochemical oxygen demand \\
& & Chemical oxygen demand
\end{tabular}

${ }^{\mathrm{a}}$ Chemical oxygen demand analyses are not required by the Wastewater Discharge Permit.

A summary of analytical results for physical parameters and metals from the SNL/CA sanitary sewer outfall is presented in Table 5-3. In 2006, all liquid effluent from the outfall complied with the site outfall discharge limits for regulated physical parameters and metals. 
Table 5-3 Weekly Composite Sewer Outfall Monitoring Results - Physical Parameters and Metals, 2006

\begin{tabular}{|c|c|c|c|c|c|c|}
\hline Parameter & $\begin{array}{l}\text { Number of } \\
\text { Samples } \\
\text { Analyzed }\end{array}$ & $\begin{array}{l}\text { Quantity } \\
\text { Found Below } \\
\text { Detection } \\
\text { Limit } \\
\end{array}$ & $\begin{array}{l}\text { Detection } \\
\text { Limit }\end{array}$ & $\begin{array}{l}\text { Sewer } \\
\text { Discharge } \\
\text { Limit }\end{array}$ & $\begin{array}{l}\text { Minimum } \\
\text { Concentration }\end{array}$ & $\begin{array}{l}\text { Maximum } \\
\text { Concentration }\end{array}$ \\
\hline $\begin{array}{l}\text { Total suspended } \\
\text { solids }\end{array}$ & 12 & 0 & $5 \mathrm{mg} / \mathrm{L}$ & None & $91 \mathrm{mg} / \mathrm{L}$ & 1700 mg/L \\
\hline $\begin{array}{l}\text { Total dissolved } \\
\text { solids }\end{array}$ & 12 & 0 & $5 \mathrm{mg} / \mathrm{L}$ & None & $83 \mathrm{mg} / \mathrm{L}$ & $260 \mathrm{mg} / \mathrm{L}$ \\
\hline $\begin{array}{l}\text { Biochemical } \\
\text { oxygen demand }\end{array}$ & 12 & 0 & $5 \mathrm{mg} / \mathrm{L}$ & None & $520 \mathrm{mg} / \mathrm{L}$ & $1300 \mathrm{mg} / \mathrm{L}$ \\
\hline $\begin{array}{l}\text { Chemical oxygen } \\
\text { demand }^{\text {a }}\end{array}$ & 12 & 0 & $5 \mathrm{mg} / \mathrm{L}$ & None & $15 \mathrm{mg} / \mathrm{L}$ & $610 \mathrm{mg} / \mathrm{L}$ \\
\hline Cyanide & 12 & 12 & $\begin{array}{l}0.01-0.02 \\
\mathrm{mg} / \mathrm{L}\end{array}$ & $0.04 \mathrm{mg} / \mathrm{L}$ & $<0.01 \mathrm{mg} / \mathrm{L}$ & $<0.02 \mathrm{mg} / \mathrm{L}$ \\
\hline Arsenic & 52 & 37 & $0.005 \mathrm{mg} / \mathrm{L}$ & $0.06 \mathrm{mg} / \mathrm{L}$ & $<0.005 \mathrm{mg} / \mathrm{L}$ & $0.01 \mathrm{mg} / \mathrm{L}$ \\
\hline Cadmium & 52 & 49 & $\begin{array}{l}0.001-0.005 \\
\mathrm{mg} / \mathrm{L}\end{array}$ & $0.14 \mathrm{mg} / \mathrm{L}$ & $<0.001 \mathrm{mg} / \mathrm{L}$ & $0.011 \mathrm{mg} / \mathrm{L}$ \\
\hline Chromium & 52 & 48 & $0.01 \mathrm{mg} / \mathrm{L}$ & $0.62 \mathrm{mg} / \mathrm{L}$ & $<0.01 \mathrm{mg} / \mathrm{L}$ & $0.013 \mathrm{mg} / \mathrm{L}$ \\
\hline Copper & 52 & 0 & $0.01 \mathrm{mg} / \mathrm{L}$ & $1 \mathrm{mg} / \mathrm{L}$ & $0.021 \mathrm{mg} / \mathrm{L}$ & $0.46 \mathrm{mg} / \mathrm{L}$ \\
\hline Lead & 52 & 50 & $0.05 \mathrm{mg} / \mathrm{L}$ & $0.2 \mathrm{mg} / \mathrm{L}$ & $<0.05 \mathrm{mg} / \mathrm{L}$ & $0.07 \mathrm{mg} / \mathrm{L}$ \\
\hline Mercury & 52 & 46 & $0.0005 \mathrm{mg} / \mathrm{L}$ & $0.01 \mathrm{mg} / \mathrm{L}$ & $<0.0005 \mathrm{mg} / \mathrm{L}$ & $0.0074 \mathrm{mg} / \mathrm{L}$ \\
\hline Nickel & 52 & 52 & $0.02 \mathrm{mg} / \mathrm{L}$ & $0.61 \mathrm{mg} / \mathrm{L}$ & $<0.02 \mathrm{mg} / \mathrm{L}$ & $<0.02 \mathrm{mg} / \mathrm{L}$ \\
\hline Silver & 52 & 52 & $0.01 \mathrm{mg} / \mathrm{L}$ & $0.2 \mathrm{mg} / \mathrm{L}$ & $<0.01 \mathrm{mg} / \mathrm{L}$ & $0.01 \mathrm{mg} / \mathrm{L}$ \\
\hline Zinc & 52 & 2 & $0.02 \mathrm{mg} / \mathrm{L}$ & $3 \mathrm{mg} / \mathrm{L}$ & $<0.02 \mathrm{mg} / \mathrm{L}$ & $0.66 \mathrm{mg} / \mathrm{L}$ \\
\hline
\end{tabular}

${ }^{\mathrm{a}}$ Chemical oxygen demand analyses are not required by the Wastewater Discharge Permit.

Sewer outfall samples are also analyzed for priority pollutants that are listed by the U.S. Environmental Protection Agency (EPA) as toxic organics. Because the list is lengthy, SNL/CA routinely reports only positively identified organic constituents. In 2006, sewer outfall samples showed concentrations of acetone $(<5-330 \mu \mathrm{g} / \mathrm{L})$, chloroform $(5.1-12$ $\mu \mathrm{g} / \mathrm{L}$ ), and bromoform at $22 \mu \mathrm{g} / \mathrm{L}$. All other constituents on the EPA toxic organic list were below minimum detection limits. The toxic organic discharge limit for the site is $1000 \mu \mathrm{g} / \mathrm{L}$. In 2006, SNL/CA did not exceed this discharge limit.

\subsubsection{Liquid Effluent Control System}

Effluent from major laboratory facilities is diverted to LECS holding tanks where wastewater can be sampled and analyzed prior to release to the sewer system. SNL/CA operated six LECS for the majority of 2006. During 2006, the Printed Circuit Board laboratory and LECS that supported this laboratory were shut down. Wastewater from LECS tanks is typically analyzed for metals. Analyses for other parameters associated with the process generating the wastewater may also be done. Four of the five remaining LECS tanks are also continuously monitored for $\mathrm{pH}$. One LECS tank is monitored every few years for tritium and uranium; however, in 2006, analyses for radioactive constituents were not warranted.

Wastewater that does not meet the discharge limits at the sewer outfall is transferred to Waste Management for disposal. Depending on the constituents of the wastewater, it may be 
disposed as hazardous or non-hazardous waste. In 2006, SNL/CA disposed of one tank of non-hazardous wastewater through Sandia’s Waste Management Program due to contamination of the wastewater with diesel fuel.

\subsubsection{Categorical Processes}

Three research operations at SNL/CA are defined as federal categorical processes subject to the EPA's pretreatment standards for point sources (40 CFR Part 403, 40 CFR Part 433). These categorical processes include two metal finishing operations and a semiconductor manufacturing operation. ${ }^{10}$ Wastewater from the semiconductor manufacturing operation is sampled semiannually. The two metal finishing operations are closed-loop systems that do not discharge effluent to the sanitary sewer, and, therefore, wastewater monitoring is not required. A fourth categorical process, the Printed Circuit Board laboratory, had been monitored in past years but was shut down in February 2006. No wastewater samples were collected from the Printed Circuit Board operation in 2006.

Samples collected from the semiconductor manufacturing operation are analyzed for $\mathrm{pH}$, arsenic, and toxic organic pollutants. Table 5-4 presents a summary of semiannual monitoring results for the semiconductor manufacturing operation. In 2006, all wastewater from this operation met the pretreatment standards.

Table 5-4 Monitoring for Semiconductor Manufacturing Categorical Process, 2006

\begin{tabular}{lllllll}
\hline Parameter & $\begin{array}{l}\text { Number } \\
\text { of } \\
\text { Samples } \\
\text { Analyzed }\end{array}$ & $\begin{array}{l}\text { Number } \\
\text { Found } \\
\text { Below } \\
\text { Detection } \\
\text { Limit }\end{array}$ & $\begin{array}{l}\text { Detection } \\
\text { Limit }\end{array}$ & $\begin{array}{l}\text { Minimum } \\
\text { Concentration }\end{array}$ & $\begin{array}{l}\text { Maximum } \\
\text { Concentration }\end{array}$ & $\begin{array}{l}\text { Permit } \\
\text { Limit }\end{array}$ \\
& 2 & -- & None & 6.5 & 7.0 & $5-10^{\mathrm{b}}$ \\
\hline $\mathrm{pH}$ & 2 & 2 & $0.002 \mathrm{mg} / \mathrm{L}$ & $<0.002 \mathrm{mg} / \mathrm{L}$ & $<0.002 \mathrm{mg} / \mathrm{L}$ & $2.09 \mathrm{mg} / \mathrm{L}$ \\
\hline Arsenic & 2 & -- & Range & $<0.02 \mathrm{mg} / \mathrm{L}$ & $<0.05 \mathrm{mg} / \mathrm{L}$ & $1.37 \mathrm{mg} / \mathrm{L}^{\mathrm{c}}$ \\
\hline $\begin{array}{l}\text { Total toxic } \\
\text { organics }\end{array}$ & & & & & \\
\hline
\end{tabular}

\subsection{Groundwater}

SNL/CA has seven groundwater monitoring wells. Sandia monitors groundwater at two former restoration areas and along Arroyo Seco. Three groundwater monitoring wells are used to monitor residual contamination at former restoration areas under a 1989 site clean-up order issued by the Regional Water Quality Control Board, San Francisco Bay Region (RWQCB). Two of these wells are located at the Fuel Oil Spill site, and one at the Navy Landfill. Four monitoring wells are located along Arroyo Seco to monitor the effect of site operations on groundwater quality. Well AS-4 is located upgradient of the developed area of the site and provides background data about local groundwater quality. Groundwater

\footnotetext{
${ }^{10}$ The semiconductor manufacturing operation is a research and development activity exempt from local air pollution regulations.
} 
monitoring well locations are shown on Figure 5-2. MW-406, an LLNL well, is also shown on Figure 5-2. SNL/CA discontinued monitoring at this location in 2005, but will continue to report the results of LLNL's monitoring efforts that occur every two years. Table 5-5 provides the sampling schedule for each SNL/CA well location.

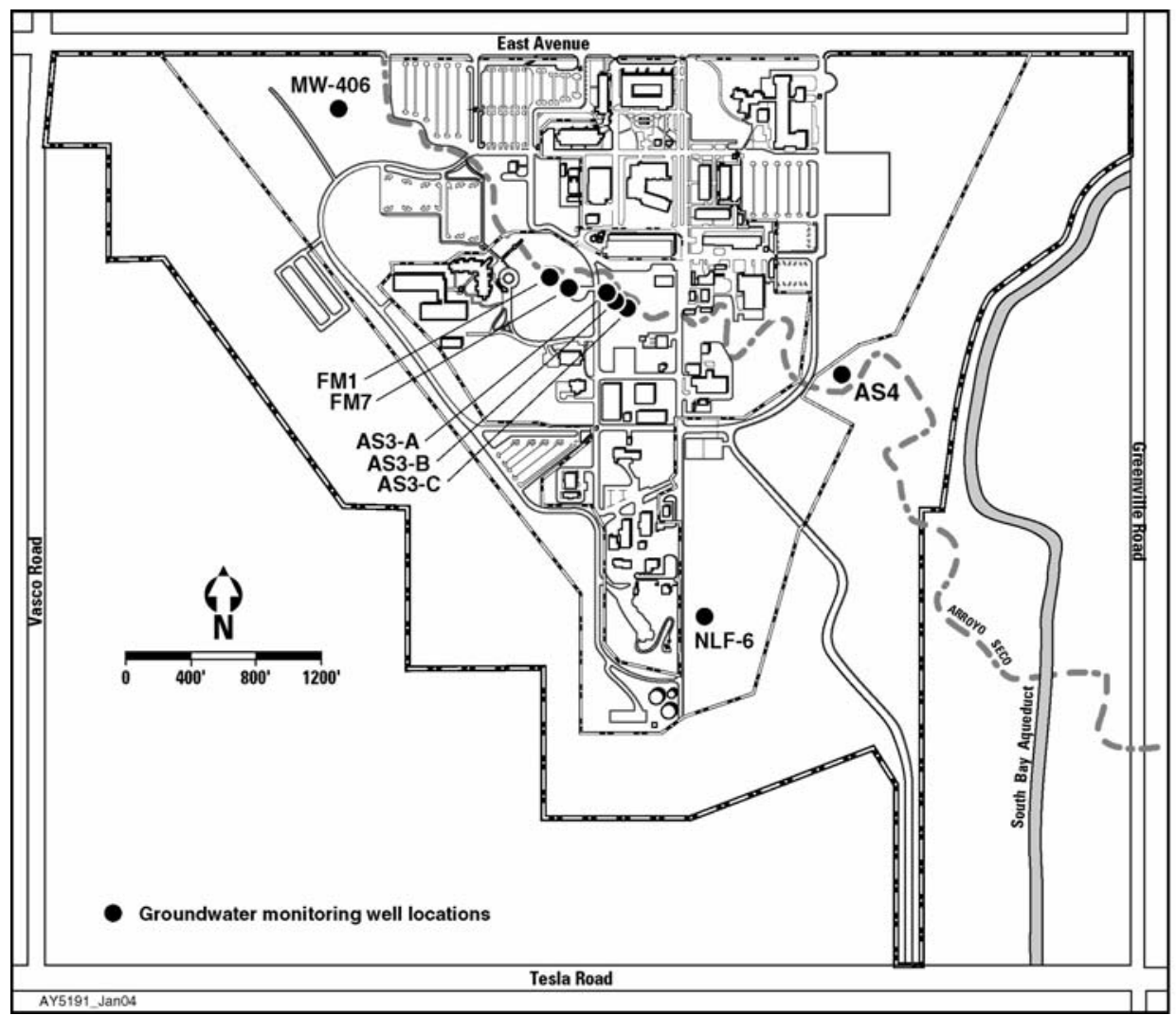

Figure 5-2 Groundwater Monitoring Well Locations

Table 5-5 Groundwater Sampling Schedule, 2006

\begin{tabular}{lll}
\hline Well location & Sampling frequency & Analytical parameter \\
\hline $\begin{array}{l}\text { Fuel Oil Spill site } \\
\text { (Wells FM-1, FM-7) }\end{array}$ & Semi-annually & $\begin{array}{l}\text { Total petroleum hydrocarbons diesel- } \\
\text { methane (TPHD) (8015); water } \\
\text { elevation }\end{array}$ \\
\hline $\begin{array}{l}\text { Navy Landfill } \\
\text { (Well NLF-6) }\end{array}$ & Annually & $\begin{array}{l}\text { Volatile halogenated organics (EPA } \\
601) ; \text { water elevation }\end{array}$ \\
\hline $\begin{array}{l}\text { Arroyo Seco } \\
\text { (Wells AS-3A, AS-3B, AS-3C, and }\end{array}$ & Annually & $\begin{array}{l}\text { Metals, volatile halogenated organics } \\
\text { (EPA 601), total petroleum }\end{array}$ \\
AS-4) & & $\begin{array}{l}\text { hydrocarbons-diesel (8015), tritium, } \\
\text { water elevation }\end{array}$ \\
\hline Arroyo Seco & Every two years & General minerals \\
(Wells AS-3A, AS-3B, AS-3C, and & & \\
AS-4) & & \\
\hline
\end{tabular}

Table 5-6 presents a summary of groundwater analytical results for the Navy Landfill. Groundwater analytical results for Arroyo Seco wells are summarized in Tables 5-7 and 5-8. All wells at the Fuel Oil Spill had insufficient water for sampling during 2006; consequently, 
no samples were collected. LLNL did not sample MW-406 in 2006; consequently there is no data available for the Trudell Auto Repair site. Complete groundwater analytical results are provided in Chapter 9. As a point of reference, analytical results are compared to federal and state maximum contaminant levels (MCLs), which are applicable for drinking water sources. There are no wells at SNL/CA used as a source for drinking water and MCLs are not standards applied to groundwater at the site.

As in past years, SNL/CA continued to detect carbon tetrachloride at the Navy Landfill well (NLF-6) in 2006. Carbon tetrachloride was detected in two samples during 2006. The concentration was above the state MCL of $0.5 \mu \mathrm{g} / \mathrm{L}$, but below the federal MCL of $5.0 \mu \mathrm{g} / \mathrm{L}$. The result is similar to that detected in past years.

Table 5-6 Summary of Groundwater Analyses at Navy Landfill, 2006

\begin{tabular}{|c|c|c|c|c|}
\hline & Date & $\begin{array}{l}\text { Trichloromethane }^{a} \\
\text { (chloroform) } \mu \mathrm{g} / \mathrm{L}\end{array}$ & $\begin{array}{l}\text { Carbon } \\
\text { Tetrachloride }^{\mathrm{a}} \mu \mathrm{g} / \mathrm{L}\end{array}$ & $\begin{array}{l}\text { Tetrachloroethene }^{\text {a }} \\
\text { (PCE) } \mu \mathrm{g} / \mathrm{L}\end{array}$ \\
\hline Detection limit & & 0.5 & 0.5 & 0.5 \\
\hline MCL - California & & & 0.5 & 5 \\
\hline MCL - Federal & & 100 & 5 & 5 \\
\hline \multicolumn{5}{|l|}{ Navy Landfill } \\
\hline NLF-6 & $6 / 14 / 06$ & $<0.5$ & 0.73 & $<0.5$ \\
\hline
\end{tabular}

${ }^{\mathrm{a}}$ All other EPA 601 parameters were non-detectable.

MCL - Maximum contaminant levels.

Table 5-7 Summary of Groundwater Analyses at Arroyo Seco Wells - Metals, 2006

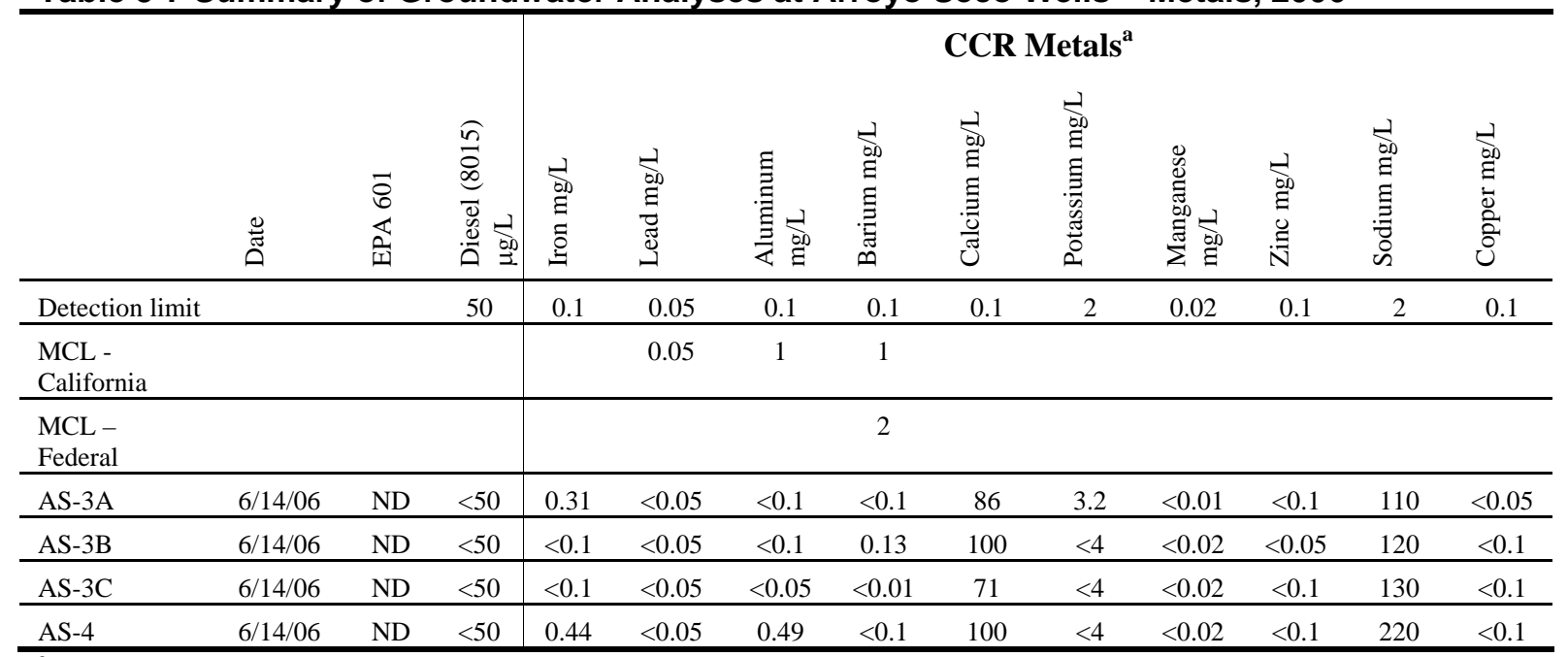

\footnotetext{
${ }^{\mathrm{a}}$ All other California Code of Regulations (CCR) parameters were non-detectable. MCL - Maximum contaminant levels.

ND - Non-detectable.
} 
Table 5-8 Summary of Groundwater Analyses at Arroyo Seco Wells - Minerals and Tritium, 2006

\section{CCR General Minerals ${ }^{\mathrm{a}}$}

\begin{tabular}{|c|c|c|c|c|c|c|c|c|c|c|c|c|c|c|}
\hline & $\stackrel{\tilde{\Xi}}{\tilde{\Xi}}$ & 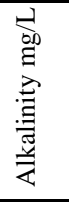 & 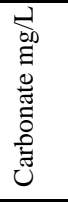 & 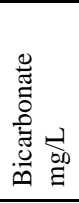 & 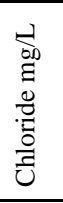 & 总 & 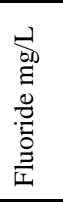 & 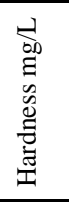 & 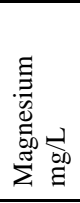 & 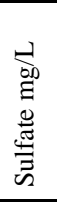 & 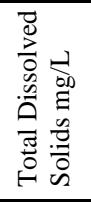 & 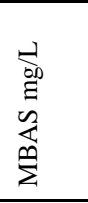 & 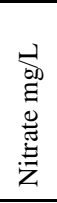 & 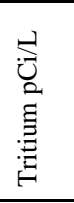 \\
\hline Detection limit & & & 1.0 & & 3.0 & 1.0 & 0.3 & 1.0 & 0.1 & 6.0 & 5.0 & 0.05 & 2 & 500 \\
\hline AS-3A & 6/14/06 & 220 & $<1.0$ & 220 & $\mathrm{~b}$ & 980 & $\mathrm{~b}$ & $\mathrm{~b}$ & 37 & $\mathrm{~b}$ & 510 & $<0.05$ & $\mathrm{~b}$ & $<500$ \\
\hline AS-3B & $6 / 14 / 06$ & 250 & $<1.0$ & 250 & 140 & 1200 & 0.3 & 500 & 48 & 180 & 760 & $<0.05$ & 15 & $<500$ \\
\hline AS-3C & $6 / 14 / 06$ & 150 & 5.7 & 140 & 69 & 820 & 0.3 & 280 & 26 & 160 & 540 & $<0.05$ & 25 & $<500$ \\
\hline AS-4 & $6 / 14 / 06$ & 460 & $<1.0$ & 460 & 180 & 1600 & 0.6 & 550 & 61 & 260 & 960 & $<0.05$ & 4.0 & $<500$ \\
\hline
\end{tabular}

a All other CCR parameters were non-detectable.

b Analysis not performed by contract laboratory.

\subsection{Biological Dose Assessment}

To meet the requirements of DOE Order 450.1 and 5400.5, SNL/CA conducts a biological dose assessment each year using the graded approach presented in DOE Standard 1153-2002 A Graded Approach for Evaluating Doses to Aquatic and Terrestrial Biota. The technical standard includes models for calculating doses from radionuclide concentration data obtained from sediment and water analyses. In 2006, the RAD-BCG Calculator, a computer tool developed by DOE, was used to calculate doses and determine the need for and level of monitoring required.

The first step in the graded approach is a general screening that compares concentrations of radionuclides in environmental media with derived concentration guides. The ratios of the concentrations to the concentration guides are then summed. If the total equals or exceeds one, then additional analyses are required.

The radionuclides handled in greatest quantity at SNL/CA during past or present operations are tritium and depleted uranium. Typically, SNL/CA uses tritium data from storm water sampling in the RAD-BCG Calculator. ${ }^{11}$ However, because tritium was not detected above analytical detection limits in storm water samples collected in 2006, the detection limit value was used. The sum of fractions from storm water data totaled $1.89 \times 10^{-6}$. This small fraction indicates that further analysis is not required and that SNL/CA is not required to monitor aquatic or terrestrial biota.

\footnotetext{
${ }^{11}$ In 2002, the first time that the RAD-BCG Calculator was used, sediment data collected by LLNL within Arroyo Seco was also used to calculate doses and determine the need for monitoring. LLNL did not analyze sediments from Arroyo Seco in 2006. SNL/CA is also not required to analyze sediments for radionuclides.
} 


\subsection{Radiation Monitoring}

SNL/CA monitors gamma radiation to ensure that site operations are not contributing significantly to the ambient radiation dose in the surrounding environment. Onsite sources that could contribute to gamma radiation include small, unsealed radioactive isotopes, sealed sources, and several radiation generating devices. SNL/CA maintains four onsite monitoring stations equipped with thermoluminescent dosimeters. Monitoring stations are shown on Figure 5-3. The dosimeters are collected and evaluated quarterly. The data obtained from Sandia monitoring stations is combined with that from LLNL monitoring stations located around the perimeter of the Sandia site to determine the average annual gamma radiation dose at the site perimeter. The combined dose is then compared to the average annual gamma radiation dose at more distant locations in the Livermore Valley, shown on Figure 5-4. If site operations were contributing significantly to the gamma radiation dose, the dosimeters at the site perimeter would show a higher dose than those at more distant locations.

In 2006, the average annual perimeter dose was 62 mrem (0.62 mSv). The average annual dose measurement for distant locations was $55 \mathrm{mrem}(0.55 \mathrm{mSv})$. The 2006 data for both perimeter and distant locations are within the range measured over the last fifteen years. Since 1992, the average annual dose at the SNL/CA perimeter ranged from 54.3 mrem to 68 mrem. Over this same period, the average annual dose measured at distant locations ranged from 53.4 mrem to 73 mrem.

Normal fluctuations and natural variations in ambient radiation are most likely the difference between the perimeter and distant location measurements for 2006. SNL/CA does not appear to be a significant contributor to gamma radiation dose in the surrounding environment. 


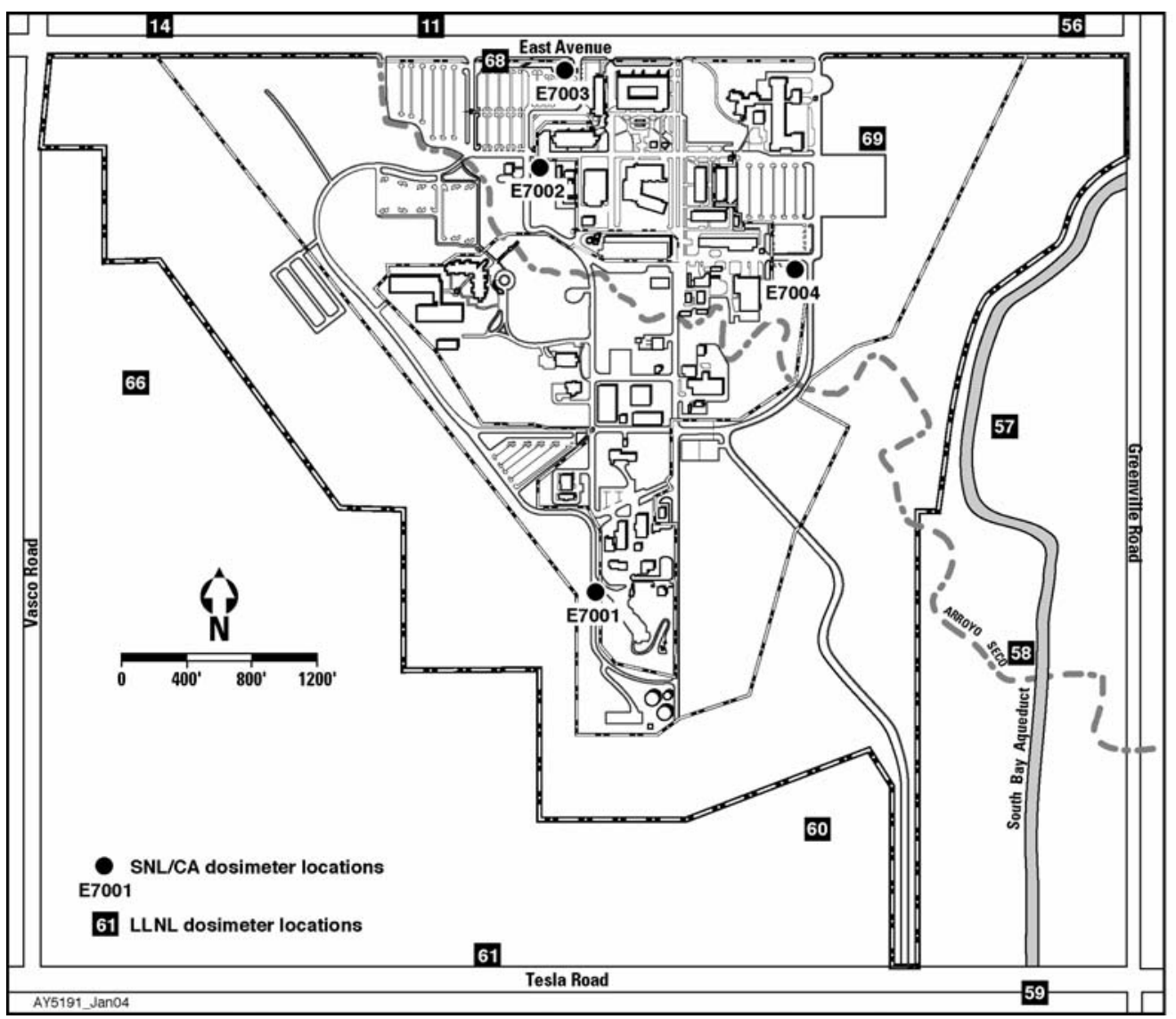

Figure 5-3 Dosimeter Locations at SNL/CA and Around Site Perimeter 


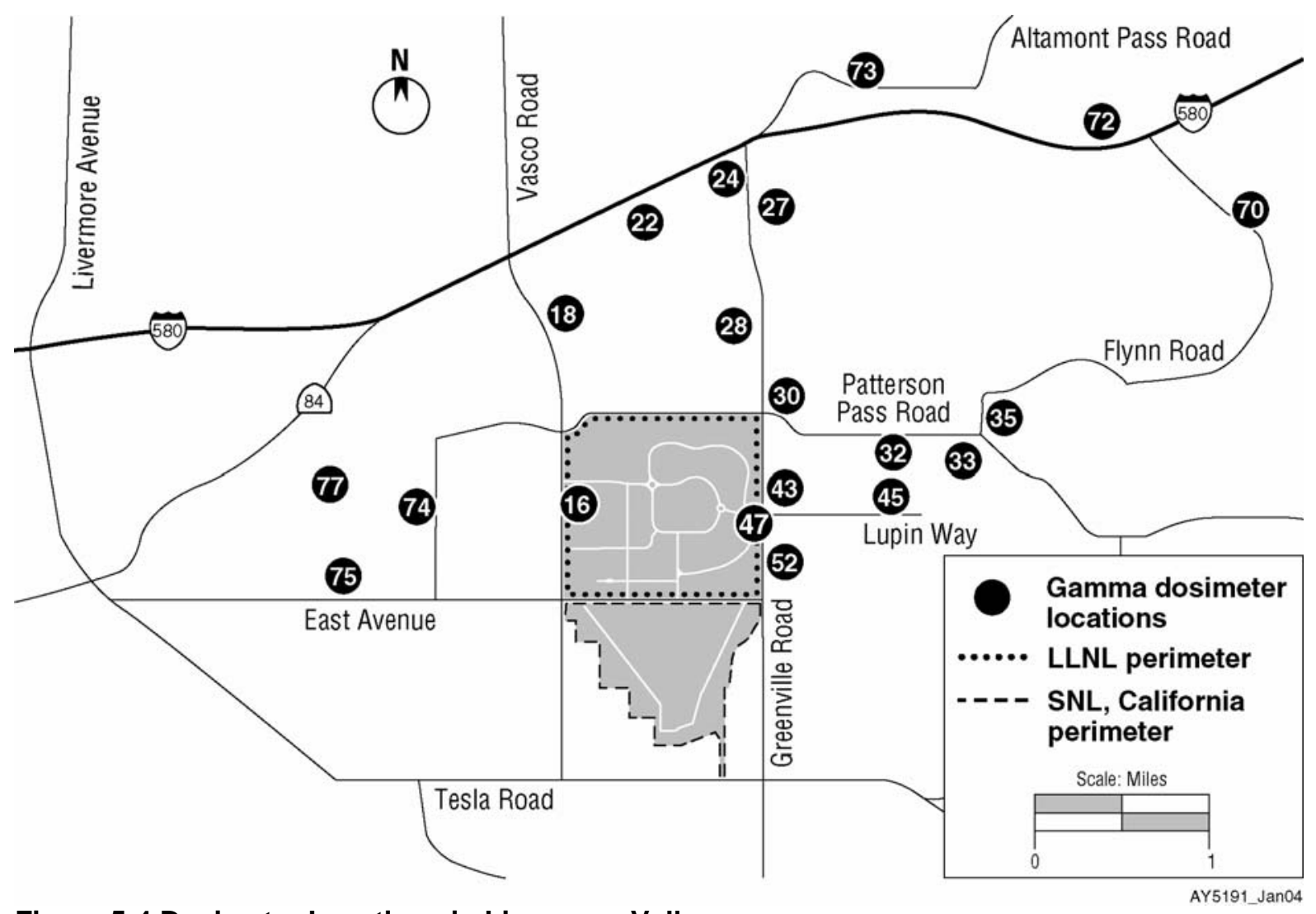

Figure 5-4 Dosimeter Locations in Livermore Valley 


\section{Quality Assurance}

The Sandia Corporate Quality Assurance Program, defined in CPR001.3.2 (SNL 2006a) is implemented at Sandia National Laboratories, California (SNL/CA) through the Sandia National Laboratories Division 8000, Quality Management Manual (SNL/CA 2006b). Compliance with the Quality Management Manual satisfies the requirements established in the Department of Energy (DOE) Nuclear Safety Management Regulations, Subpart A, Quality Assurance Requirements (10 CFR 830), and DOE Order 414.1C, Quality Assurance (DOE 2005a). The Environmental Management Department maintains a Quality Assurance Project Plan that describes the general quality requirements for SNL/CA environmental programs. Programspecific quality requirements are presented in annual program reports and

DOE Order 414.1C identifies ten criteria that are integral to a quality program:

$>$ Quality assurance program

$>$ Personnel training and qualification

$>$ Quality improvement process

$>$ Documents and records

$>$ Established work processes

$>$ Established standards for design and verification

$>$ Established procurement requirements

$>$ Inspection and acceptance testing

$>$ Management assessment

$>$ Independent assessment implemented through operating procedures.

\subsection{Environmental Monitoring Quality Assurance}

The Environmental Monitoring and Restoration Program ensures quality in its activities through implementation of quality assurance plans and procedures. A program-specific quality assurance project plan (QAPP) addresses each of the ten criteria listed above, and documents quality assurance activities performed for the program (SNL/CA 2005b). The SNL/CA Environmental Monitoring Annual Program Report provides a detailed description of the monitoring and surveillance activities conducted at SNL/CA (SNL/CA 2006a). Additional program operating procedures specify training requirements, establish work processes, define data verification and validation processes, and identify reporting and records management requirements. The operating procedures are reviewed by subject matter experts and approved by the Environmental Management Department Manager.

\subsection{Environmental Sampling}

Protocols for environmental sampling at SNL/CA are contained in activity specific operating procedures. Elements of these protocols include appropriate sampling methods and equipment; sampling frequency; sampling locations; and sample handling, storage, and packaging. Implementation of established protocols ensures that samples are representative of the environmental medium monitored and that monitoring requirements outlined in permits, DOE orders, and regulations are met. Chain-of-custody protocols are also used to 
ensure quality control through proper transfer of samples from the point of collection to the analytical laboratory.

\subsection{Sample Analyses}

Analyses of samples collected at SNL/CA are performed using one of three avenues, depending on the sample medium or constituent analyzed. The three avenues are: a State accredited laboratory; the SNL/CA Health Protection Laboratory; or the Sandia National Laboratories, New Mexico (SNL/NM) Health Instrumentation Laboratory.

\subsubsection{Accredited Laboratory}

A State of California accredited laboratory performs analyses of non-radiological samples collected at SNL/CA. To receive accreditation, a laboratory must implement a quality assurance plan. These laboratories are periodically inspected by the California Environmental Protection Agency to ensure that they are operating within regulatory and quality assurance requirements. Consistent with industry standards, non-radiological samples are processed according to federal Environmental Protection Agency methods.

\subsubsection{SNL/CA Health Physics Laboratory}

Tritium analyses of storm water are performed by the SNL/CA Health Protection Department in an onsite laboratory. These samples are analyzed by liquid scintillation counting, a standard technique for tritium analysis. The Health Physics Laboratory follows the guidance in the Sandia National Laboratories (SNL) Radiation Protection Department Quality Assurance Plan (SNL 2006c), and meets the Sandia and DOE quality criteria.

\subsubsection{SNL/NM Health Instrumentation Laboratory}

Thermoluminescent dosimeters used to collect gamma radiation measurements are processed by the Health Instrumentation Department at SNL/NM following established protocols and quality assurance/quality control requirements under the SNL Radiation Protection Department Quality Assurance Plan (SNL 2006c). Automated equipment is used to process the samples and analyze the resulting data.

\subsection{Data Verification and Validation}

SNL/CA conducts data verification and validation to ensure that environmental data is precise, accurate, representative, comparable, and complete. Verification and validation are accomplished through analyses of quality control samples and by conducting statistical analyses. 


\subsubsection{Quality Control Samples}

Types of quality control samples prepared for the Environmental Monitoring and Restoration Program include duplicate, spiked, and blank samples. A definition of each sample type follows.

$>$ Duplicate samples are collected at the same time and location, and follow the same method, as a routine sample. These samples are used to assess the precision of sample collection and analytical processes.

$>$ Spiked samples resemble a routine sample, but contain a known amount of one or more of the constituents of interest. These samples are obtained from an independent laboratory that certifies the concentration of the constituents.

> Blank samples resemble a routine sample matrix (e.g. deionized water is used for blank water samples), but lack the constituents of interest. These samples are used to assess background levels of constituents, and possible contamination of the samples in the laboratory or in the field.

SNL/CA's goal for number of quality control samples is 20 percent of the total sample load, where feasible. This includes quality control samples initiated at the laboratory. In 2006, SNL/CA collected twelve wastewater quality control samples representing 23 percent of the sample load. Four groundwater quality control samples were collected representing 27 percent of the sample load. Six storm water quality control samples were collected during the 2005/2006 wet season, representing 33 percent of the sample load.

\subsubsection{Statistical Analyses}

Statistical analyses are used to determine completeness, precision, and accuracy of monitoring and surveillance data. Prior to performing statistical analyses, the data is normalized to ensure that valid results are obtained. Descriptions of the statistical tests follow.

Completeness is evaluated by determining the ratio between the number of samples collected and the number of samples scheduled for collection. The data quality objective for completeness is 85 percent.

Precision is evaluated using three methods: determining the ratio between routine and duplicate samples; tests of significant difference; and calculating the 95 percent confidence interval. Data quality objectives vary for precision depending on the results of laboratory analyses.

Accuracy is also evaluated using three methods: determining the ratio between sample results and known values of spiked samples; tests of significant difference; and calculating the 95 percent confidence interval. Data quality objectives vary for accuracy depending on the results of laboratory analyses.

Table 6.1 summarizes the results of statistical analyses conducted in 2006. The results show that all precision tests passed. No accuracy tests were performed in 2006. The failed completeness tests for groundwater were due to falling groundwater levels and not to a failure of the sampling program. 
Table 6-1 Summary of Statistical Analyses, 2006

\begin{tabular}{|c|c|c|c|c|c|}
\hline \multirow[t]{2}{*}{ Sample Medium } & \multirow{2}{*}{$\begin{array}{l}\text { Completeness Test } \\
\text { Results } \\
\end{array}$} & \multicolumn{2}{|c|}{ Precision Test } & \multicolumn{2}{|c|}{ Accuracy Test } \\
\hline & & \# of Tests & Results & \# of Tests & Results \\
\hline $\begin{array}{l}\text { Wastewater (sanitary } \\
\text { sewer) }\end{array}$ & $100 \%$ & 6 & All passed & None & \\
\hline Storm water & $90 \%$ & 3 & 2 passed $^{\mathrm{b}}$ & None & \\
\hline Groundwater & $56 \%^{\mathrm{a}}$ & 1 & All passed & None & \\
\hline
\end{tabular}




\section{References}

22 California Code of Regulations (CCR), Division 4.5, Environmental Health Standard for Management of Hazardous Waste.

10 Code of Federal Regulations (CFR) Part 830, Department of Energy, Nuclear Safety Management, Subpart A, Quality Assurance Requirements, Federal Register Vol. 66, Number 7, January 10, 2001.

10 CFR Part 1021, Department of Energy, National Environmental Policy Act Implementing Procedures, January 1997.

40 CFR Part 61, Environmental Protection Agency, National Emissions Standards for Hazardous Air Pollutants, Subpart H - National Emissions Standards for Emissions of Radionuclides Other Than Radon From Department of Energy Facilities, December 1989.

40 CFR Part 70, Environmental Protection Agency, State Operating Permit Programs, July 1, 2005.

40 CFR Part 82, Environmental Protection Agency, Protection of Stratospheric Ozone, July $1,2004$.

40 CFR Part 262.41, Environmental Protection Agency, Standards Applicable to Generators of Hazardous Waste, Subpart D, Record-keeping and Reporting, July 1, 2001.

40 CFR Part 403, Environmental Protection Agency, General Pretreatment Regulations for Existing and New Sources of Pollution.

40 CFR Part 433, Environmental Protection Agency, Metal Finishing Point Source Category.

7 United States Code (USC) §136, Federal Insecticide, Fungicide, and Rodenticide Act, 1972.

15 USC §2601 et. seq., Toxic Substances Control Act of 1976.

16 USC § 470, National Historic Preservation Act of 1966.

16 USC § 703 et. seq., Migratory Bird Treaty Act of 1918.

16 USC §1531 et. seq., Endangered Species Act of 1973.

33 USC §1251, Clean Water Act of 1977.

42 USC § 2011 et. seq., Atomic Energy Act of 1954. 
42 USC § 6901 et. seq., Resource Conservation and Recovery Act of 1976.

42 USC § 6961, Federal Facility Compliance Act of 1992.

42 USC § 7401, Clean Air Act Amendments of 1990.

42 USC § 9601, Comprehensive Environmental Response, Compensation, and Liability Act of 1980.

42 USC §11001 et. seq., Superfund Amendments and Reauthorization Act of 1986, Emergency Planning and Community Right-to-Know Act.

42 USC §13101 et. seq., Pollution Prevention Act of 1990.

Assembly Bill 2185, California Hazardous Materials Release Response Plans and Inventory Law, 1987.

California Health and Safety Code, Division 20, Chapter 6.5, § 25100 et. seq., Hazardous Waste Control Law.

California Health and Safety Code, Division 20, Chapter 6.7, §§ 25280-25299.8, Underground Storage of Hazardous Substances.

California Health and Safety Code, Division 20, Chapter 6.95, § 25500, et. Seq., Hazardous Materials Release Response Plans and Inventory.

California Health and Safety Code, Division 104, Part 14, §§ 117600-118360, Medical Waste Management Act.

California Regional Water Quality Control Board, San Francisco Bay Region (California RWQCB) 1989, Order No. 89-184, Revision of Site Cleanup Order, Sandia Corporation and U.S. Department of Energy, Livermore, December 1989.

California Water Resources Control Board 1997, State of California, NPDES General Permit for Storm Water Discharge Associated with Industrial Activities, April 1997.

Department of Energy (DOE) 1986, Comprehensive Environmental Assessment and Response Program, Phase I: Installation Assessment, Sandia National Laboratories, Livermore, September, 1986.

DOE 1993, DOE Order 5400.5, change 2, Radiation Protection of the Public and the Environment, January 7, 1993.

DOE 2001, DOE Order 435.1, change 1, Radioactive Waste Management, August 28, 2001.

DOE 2003a, Final Site-wide Environmental Assessment of the Sandia National Laboratories/California, DOE/EA-1422, January 2003. 
DOE 2003b, Site Wide Environmental Assessment for SNL/CA, Finding of No Significant Impact, March 20, 2003.

DOE 2004a, DOE Order 231.1A, change 1, Environment, Safety, and Health Reporting, June 3, 2004.

DOE 2004b, DOE G 450.1-3, Environmental Guidelines for Development of Cultural Resource Management Plans - Update, September 22, 2004.

DOE 2005a, DOE Order 414.1C, Quality Assurance, June 17, 2005.

DOE 2005b, DOE order 450.1, change 2, Environmental Protection Program, December 7, 2005.

Executive Order (EO) 11988, Floodplain Management, Federal Register, Vol. 42, pp. 26951, May 25, 1977.

EO 11990, Protection of Wetlands, Federal Register, Vol. 42, pp. 26961, May 25, 1977.

EO 13101, Greening the Government Through Waste Prevention, Recycling, and Federal Acquisition, September 14, 1998.

EO 13148, Greening of the Government Through Leadership in Environmental Management, April 21, 2000.

EO 13423, Strengthening Federal Environmental, Energy, and Transportation Management, January 24, 2007.

House of Representatives H.R. 6 Conference Report 2005 (HR 2005), Energy Policy Act of 2005, August 8, 2005.

Lawrence Livermore National Laboratory (LLNL) 2006, LLNL Daily Statistics Weather Report, http://www-metdat.llnl.gov/cgi-pub/metdat/generate_daily_report.pl, January 4, 2007.

Matthews, Graham \& Associates (Matthews) 2002, Management Plan for Arroyo Seco at Sandia National Labs, Livermore, CA, April 2002.

Sandia National Laboratories (SNL) 2002, Historic Building Survey, Sandia National Laboratories/California, October 30, 2002.

SNL 2006a, Corporate Quality Assurance Program, Corporate Process Requirements No. CPR001.3.2, http://www-irn.sandia.gov/policy/leadership/quality.html, February 20, 2006.

SNL 2006b, Environment, Health, and Safety Manual (MN 471001), Section 6S - Toxic Substances Control Act (TSCA), June 28, 2006. 
SNL 2006c, Radiation Protection Department Quality Assurance Plan, RPA-01-01, July 1, 2006.

SNL California (SNL/CA) 2002, Sandia National Laboratories, California Environmental Information Document, SAND 2002-8053, March 2002.

SNL/CA 2004a, Operating Procedure 471741, Storm Drain Spill Prevention and Control, Issue C, July 15, 2004.

SNL/CA 2004b, Standard Operating Procedure SP471911, Handling and Storage of Pesticides, May 10, 2004.

SNL/CA 2005a, Administrative Procedure for Conducting National Environmental Policy Act Reviews of Proposed Projects at Sandia National Laboratories, California, OP471343, Issue I, April 30, 2005.

SNL/CA 2005b, Quality Assurance Project Plan for Environmental Monitoring Program, SAND 2005-6051, September 20, 2005.

SNL/CA 2006a, Sandia National Laboratories, California Environmental Monitoring Annual Program Report for 2005, SAND 2006-1024, February 2006.

SNL/CA 2006b, Sandia National Laboratories Division 8000 Quality Management Manual, https://wfsprod01.sandia.gov/groups/srnuscitizens/documents/document/wfs276273.pdf, October 30, 2006.

SNL/CA 2006c, 2006 Annual Report on Waste Generation and Pollution Prevention Progress (as required by DOE Order 450.1, Section 5 a (2)(b), November 30, 2006.

SNL/CA 2007, Sandia National Laboratories, California 2005 Emission Inventory of Mobile Sources, Annual Progress Report, January 2007.

Senate Bill 14, California Hazardous Waste Source Reduction and Management Review Act of 1989.

United States District Court for the District of Columbia (US District Court) 2002, Case Number 01-1291 (RJL), Home Builders Associations of Northern California, et al., Plaintiffs, and El Dorado County, California, Intervenor-Plaintiff, v. Gale A. Norton, Secretary of the Department of Interior, et. al., Defendants, and Jumping Frog Research Institute, et al., Intervenor-Defendants, November 6, 2002.

US District Court, Northern District of California 2006, Case Number 02-1580-JSW (JL), Stipulated Injunction and Order, Center for Biological Diversity, Plaintiff, v. Stephen L. Johnson, Administrator, Environmental Protection Agency, and Wayne Nastri, Region 9 Administrator, Environmental Protection Agency, Defendants, and Croplife America, American Forest \& Paper Association, Western Plant Health Association, Oregonians for Food and Shelter, and Syngenta Crop Protection, Inc., DefendantsIntervenors, October 17, 2006. 
United States Fish and Wildlife Service (USFWS) 2004, Proposed Rule, Endangered and Threatened Wildlife and Plants; Proposed Designation of Critical habitat for the California Red-legged Frog (Rana aurora draytonii), Federal Register, April 13, 2004 (Volume 69, Number 71).

USFWS 2005, Proposed Rule, Endangered and Threatened Wildlife and Plants: Revised Proposed Designation of Critical Habitat for the California Red-Legged Frog (Rana aurora draytonii), Federal Register, November 3, 2005 (Volume 70, Number 212).

USFWS 2006, Final Rule, Endangered and Threatened Wildlife and Plants; Designation of Critical Habitat for the California Red-Legged Frog, and Special Rule Exemption Associated with Final Listing for Existing Routine Ranching Activities, Federal Register, April 13, 2006 (Volume 71, Number 71). 
SNL/CA Site Environmental Report for 2006

Page Intentionally Left Blank 


\section{Glossary}

Ambient air

Biochemical

oxygen demand

British thermal unit

Categorical process

Chemical oxygen

demand

Dose

Dosimeter

Effluent

Emission

Ephemeral stream

External radiation

Fluvial sediments

Lacustrine

sediments

Mixed waste
The surrounding atmosphere, usually the outside air, as it exists around people, plants, and structures. It does not include the air next to emission sources.

A measure of the amount of dissolved oxygen that microorganisms need to break down organic matter in water. Used as an indicator of water quality.

BTU is the quantity of heat required to raise the temperature of one pound of water from $60^{\circ}$ to $61^{\circ} \mathrm{F}$ at a constant pressure of one atmosphere.

An industrial process that discharges wastewater and is regulated under 40 CFR, Part 403.

The amount of oxygen required to degrade the organic compounds of wastewater. Used to measure the overall level of organic contamination in wastewater.

A term denoting the quantity of radiation energy absorbed.

A portable detection device for measuring the total accumulated exposure to ionizing radiation.

A liquid or gaseous waste discharged to the environment.

A gaseous or liquid stream containing one or more contaminants.

A stream that flows only for a short duration during and following rainfall.

Radiation originating from a source outside the body.

A sedimentary deposit consisting of material transported by, suspended in, or laid down by a river or stream.

Sediments formed in, or relating to, a lake.

Waste that contains both radioactive and hazardous constituents. 
$\mathrm{pH} \quad$ A measure of hydrogen ion concentration in an aqueous solution. Acidic solutions have a $\mathrm{pH}$ less than 7 , basic solutions have a $\mathrm{pH}$ greater than 7 , and neutral solutions have a $\mathrm{pH}$ of 7.

Riparian Pertaining to, situated in, or adapted to living on the banks of rivers and streams.

Specific Measure of the ability of a material to conduct electricity.

conductivity

Strike-slip fault A fault with horizontal movement along the break where slipping is parallel with the strike of the fault.

Thermoluminescent A type of dosimeter. After being exposed to radiation, the material in dosimeter the dosimeter (lithium fluoride) luminesces upon being heated. The amount of light the material emits is proportional to the amount of radiation (dose) to which it was exposed.

Total dissolved Solids in water that pass through a filter. A measure of the amount of solids material dissolved in water.

Total suspended Solids in water that can be trapped in a filter. Solids can include silt, solids decaying plant and animal matter, industrial wastes, and sewage.

Transverse fault A fault that strikes obliquely or perpendicular to the general structural trend of the region. 


\section{Groundwater Analytical Results and Well Completion Data}


Table 9-1 Results of Quarterly Groundwater Analyses at SNL/CA, 2006

\begin{tabular}{|c|c|c|c|c|c|c|c|c|c|c|c|c|c|c|c|c|c|c|}
\hline & Date & 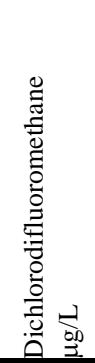 & 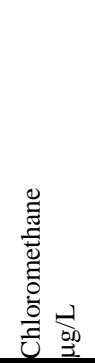 & 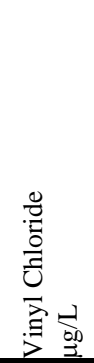 & 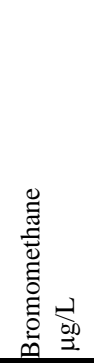 & 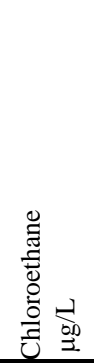 & 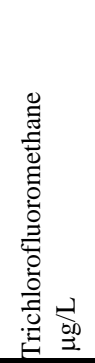 & 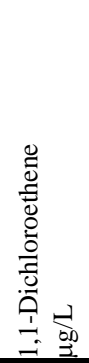 & 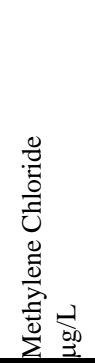 & 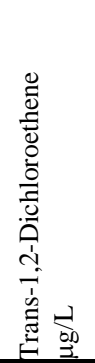 & 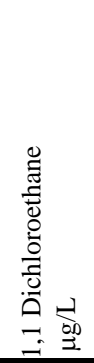 & 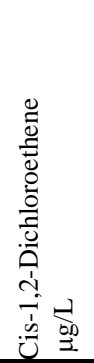 & 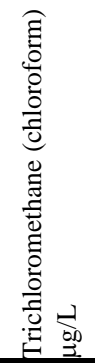 & 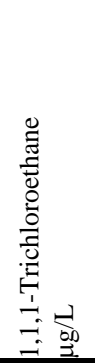 & 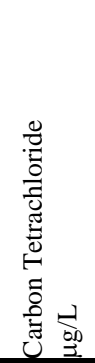 & 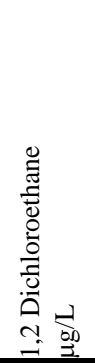 & 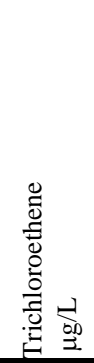 & 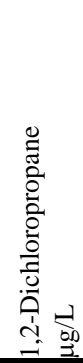 \\
\hline $\begin{array}{l}\text { Detection } \\
\text { limit }\end{array}$ & Detection & 2.0 & 0.5 & 1.0 & 1.0 & 0.5 & 0.5 & 0.5 & 2.0 & 0.5 & 0.5 & 0.5 & 0.5 & 0.5 & 0.5 & 0.5 & 0.5 & 0.5 \\
\hline \multicolumn{19}{|l|}{ MCL - } \\
\hline \multicolumn{19}{|l|}{ MCL - } \\
\hline \multicolumn{19}{|l|}{ Well ID } \\
\hline \multirow[t]{3}{*}{ NLF-6 } & $6 / 14 / 06$ & ND & ND & ND & ND & ND & ND & ND & ND & ND & ND & ND & ND & ND & 0.73 & ND & ND & ND \\
\hline & $6 / 14 / 06^{a}$ & ND & ND & ND & ND & ND & ND & ND & ND & ND & ND & ND & ND & ND & 0.68 & ND & ND & ND \\
\hline & $6 / 14 / 06^{b}$ & ND & ND & ND & ND & ND & ND & ND & ND & ND & ND & ND & ND & ND & ND & ND & ND & ND \\
\hline AS-3A & $6 / 14 / 06$ & ND & ND & ND & ND & ND & ND & ND & ND & ND & ND & ND & ND & ND & ND & ND & ND & ND \\
\hline AS-3B & $6 / 14 / 06$ & ND & ND & ND & ND & ND & ND & ND & ND & ND & ND & ND & ND & ND & ND & ND & ND & ND \\
\hline AS-3C & $6 / 14 / 06$ & ND & ND & $\mathrm{ND}$ & ND & ND & ND & ND & ND & ND & ND & ND & ND & ND & ND & ND & ND & ND \\
\hline FM-1 ${ }^{\mathrm{C}}$ & & -- & -- & -- & -- & -- & -- & -- & -- & -- & -- & -- & -- & -- & -- & -- & -- & -- \\
\hline${\mathrm{FM}-7^{\mathrm{C}}}$ & & -- & -- & -- & -- & -- & -- & -- & -- & -- & -- & -- & -- & -- & -- & -- & -- & -- \\
\hline AS-4 & $\begin{array}{l}6 / 14 / 06 \\
\end{array}$ & -- & -- & -- & -- & -- & -- & -- & -- & -- & -- & -- & -- & -- & -- & -- & -- & -- \\
\hline Trip Blank & 6/14/06 & ND & ND & ND & ND & ND & ND & ND & ND & ND & ND & ND & ND & ND & ND & ND & ND & ND \\
\hline \multicolumn{19}{|c|}{$\begin{array}{l}\text { MCL - Maximum contaminant level. } \\
\text { ND - Non-detectable. } \\
\text {-- Not required to analyze or sample not collected. } \\
{ }^{a} \text { Field duplicate sample. } \\
\text { b Field blank sample. } \\
{ }^{c} \text { Well was dry during } 2006 .\end{array}$} \\
\hline
\end{tabular}


Table 9-1 Results of Groundwater Analyses at SNL/CA, 2006 (continued)

\begin{tabular}{|c|c|c|c|c|c|c|c|c|c|c|c|c|c|c|c|c|c|c|c|}
\hline & Date & 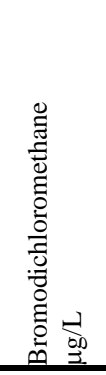 & 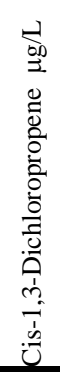 & 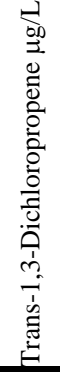 & 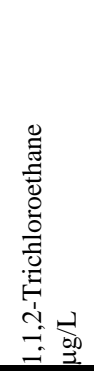 & 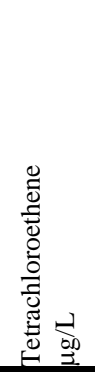 & 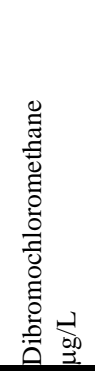 & 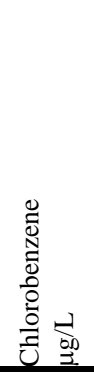 & 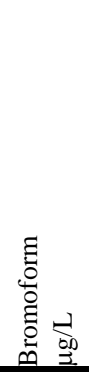 & 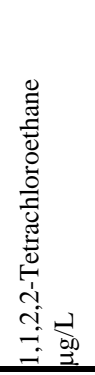 & 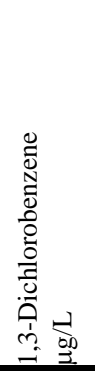 & 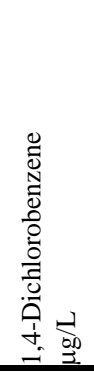 & 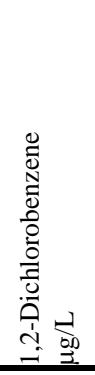 & 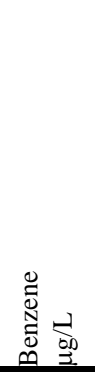 & 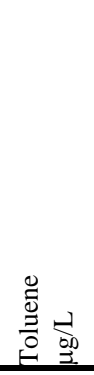 & 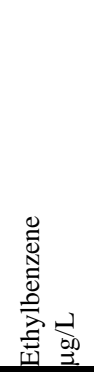 & 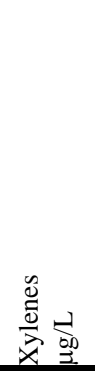 & 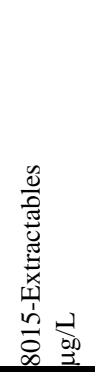 & 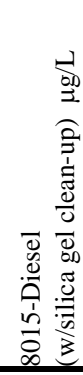 \\
\hline $\begin{array}{l}\text { Detection } \\
\text { limit }\end{array}$ & & 0.5 & 0.5 & 0.5 & 0.5 & 0.5 & 0.5 & 0.5 & 0.5 & 0.5 & 0.5 & 0.5 & 0.5 & 0.5 & 0.5 & 0.5 & 0.5 & 50 & 50 \\
\hline $\begin{array}{l}\text { MCL - } \\
\text { California } \\
\end{array}$ & & & 0.5 & & 32 & 5 & & 30 & & 1 & & 5 & & 1 & & & 1750 & & \\
\hline $\begin{array}{l}\text { MCL - } \\
\text { Federal }\end{array}$ & & 100 & & & 5 & 5 & 100 & 100 & 100 & & 600 & 75 & 600 & 5 & 1000 & 700 & 10000 & & \\
\hline Well ID & & & & & & & & & & & & & & & & & & & \\
\hline NLF-6 & $6 / 14 / 06$ & ND & ND & ND & ND & ND & ND & ND & ND & ND & ND & ND & ND & -- & -- & -- & -- & -- & -- \\
\hline & $6 / 14 / 06^{\mathrm{a}}$ & ND & $\mathrm{ND}$ & ND & $\mathrm{ND}$ & $\mathrm{ND}$ & $\mathrm{ND}$ & ND & ND & ND & ND & $\mathrm{ND}$ & ND & -- & -- & -- & -- & -- & -- \\
\hline & $6 / 14 / 06^{b}$ & ND & $\mathrm{ND}$ & ND & $\mathrm{ND}$ & $\mathrm{ND}$ & $\mathrm{ND}$ & ND & ND & ND & ND & ND & ND & -- & -- & -- & -- & -- & -- \\
\hline AS-3A & $6 / 14 / 06$ & ND & ND & ND & $\mathrm{ND}$ & ND & $\mathrm{ND}$ & ND & ND & ND & ND & ND & ND & -- & -- & -- & -- & -- & ND \\
\hline AS-3B & 6/14/06 & ND & ND & ND & ND & ND & ND & ND & ND & ND & ND & ND & ND & -- & -- & -- & -- & -- & ND \\
\hline AS-3C & $6 / 14 / 06$ & ND & ND & ND & ND & ND & ND & ND & ND & ND & ND & ND & ND & -- & -- & -- & -- & -- & ND \\
\hline FM-1 ${ }^{\mathrm{c}}$ & & -- & -- & -- & -- & -- & -- & -- & -- & -- & -- & -- & -- & -- & -- & -- & -- & -- & -- \\
\hline FM-7 $^{\mathrm{C}}$ & & -- & -- & -- & -- & -- & -- & -- & -- & -- & -- & -- & -- & -- & -- & -- & -- & -- & -- \\
\hline AS-4 & $\begin{array}{l}6 / 14 / 06 \\
\end{array}$ & ND & ND & ND & ND & ND & ND & ND & ND & ND & ND & $\mathrm{ND}$ & ND & -- & -- & -- & -- & -- & ND \\
\hline Trip Blank & $6 / 14 / 06$ & ND & ND & ND & ND & ND & ND & ND & ND & ND & ND & ND & ND & -- & -- & -- & -- & -- & -- \\
\hline $\begin{array}{l}\text { MCL - Max } \\
\text { ND - Non-c } \\
\text {-- Not requi } \\
\text { a Field dupli } \\
{ }^{\mathrm{b}} \text { Field blank } \\
{ }^{\mathrm{c}} \text { Well was }\end{array}$ & $\begin{array}{l}\text { ium contan } \\
\text { ectable. } \\
\text { to analyz } \\
\text { te sample. } \\
\text { ample. } \\
\text { during } 20\end{array}$ & tevel. & 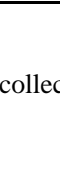 & & & & & & & & & & & & & & & & \\
\hline
\end{tabular}


Table 9-1 Results of Groundwater Analyses at SNL/CA, 2006 (continued)

\begin{tabular}{|c|c|c|c|c|c|c|c|c|c|c|c|c|c|c|c|c|c|c|c|}
\hline & Date & 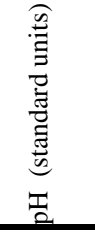 & 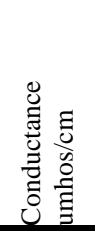 & 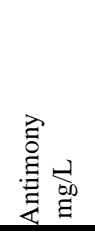 & 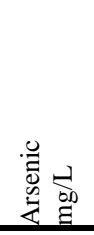 & 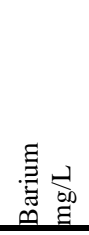 & 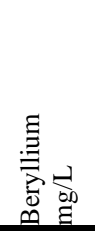 & 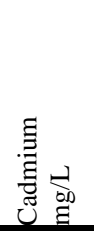 & 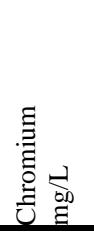 & 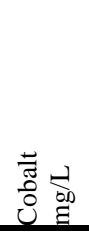 & 芯 & ت્ّ & 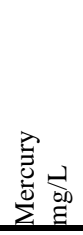 & 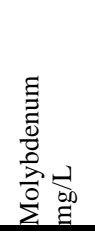 & 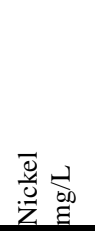 & 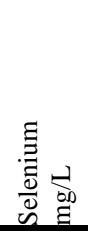 & 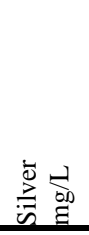 & 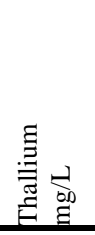 & 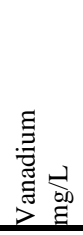 \\
\hline \multicolumn{19}{|l|}{ Detection } & 0.01 \\
\hline $\begin{array}{l}\text { MCL - } \\
\text { California }\end{array}$ & & & & & 0.05 & 1 & & 0.01 & 0.05 & & $1^{\mathrm{d}}$ & 0.05 & 0.002 & & & 0.01 & 0.05 & & \\
\hline $\begin{array}{l}\text { MCL - } \\
\text { Federal } \\
\end{array}$ & & & $900^{d}$ & 0.006 & & 2 & 0.004 & 0.005 & 0.1 & & $1^{\mathrm{d}}$ & & 0.002 & & 0.1 & 0.05 & $0.1^{\mathrm{d}}$ & 0.002 & \\
\hline \multicolumn{20}{|l|}{ Well ID } \\
\hline \multirow[t]{3}{*}{ NLF-6 } & $6 / 14 / 06$ & -- & -- & -- & -- & -- & -- & -- & -- & -- & -- & -- & -- & -- & -- & -- & -- & -- & -- \\
\hline & $6 / 14 / 06^{a}$ & -- & -- & -- & -- & -- & -- & -- & -- & -- & -- & -- & -- & -- & -- & -- & -- & -- & -- \\
\hline & $6 / 14 / 06^{\mathrm{b}}$ & -- & -- & -- & -- & -- & -- & -- & -- & -- & -- & -- & -- & -- & -- & -- & -- & -- & -- \\
\hline AS-3A & $6 / 14 / 06$ & 8.0 & 980 & ND & ND & ND & ND & ND & ND & ND & ND & ND & ND & ND & ND & ND & ND & ND & ND \\
\hline AS-3B & $6 / 14 / 06$ & 8.0 & 1200 & ND & ND & 0.13 & ND & ND & ND & ND & ND & ND & ND & ND & ND & ND & ND & ND & ND \\
\hline AS-3C & $6 / 14 / 06$ & 8.3 & 820 & ND & ND & ND & ND & ND & ND & ND & ND & ND & ND & ND & ND & ND & ND & ND & ND \\
\hline FM-1 ${ }^{\mathrm{c}}$ & & -- & -- & -- & -- & -- & -- & -- & -- & -- & -- & -- & -- & -- & -- & -- & -- & -- & -- \\
\hline FM-7 $^{\text {c }}$ & & -- & -- & -- & -- & -- & -- & -- & -- & -- & -- & -- & -- & -- & -- & -- & -- & -- & -- \\
\hline AS-4 & $6 / 14 / 06$ & 7.9 & 1600 & ND & ND & ND & ND & ND & ND & ND & ND & ND & ND & ND & ND & ND & ND & ND & ND \\
\hline Trip Blank & $6 / 14 / 06$ & -- & -- & -- & -- & -- & -- & -- & -- & -- & -- & -- & -- & -- & -- & -- & -- & -- & -- \\
\hline $\begin{array}{l}\text { MCL - Max } \\
\text { ND - Non-c } \\
\text {-- Not requi } \\
{ }^{\mathrm{a}} \text { Field dupl } \\
{ }^{\mathrm{b}} \text { Field blan } \\
{ }^{\mathrm{c}} \text { Well was } \\
{ }^{\mathrm{d}} \text { Secondary }\end{array}$ & $\begin{array}{l}\text { 7um contam } \\
\text { ectable. } \\
\text { to analyze } \\
\text { te sample. } \\
\text { ample. } \\
\text { during } 200 \\
\text { inking wate }\end{array}$ & $\begin{array}{l}\text { level. } \\
\text { mple no }\end{array}$ & ollectec & & & & & & & & & & & & & & & & \\
\hline
\end{tabular}


Table 9-1 Results of Groundwater Analyses at SNL/CA, 2006 (continued)

\begin{tabular}{|c|c|c|c|c|c|c|c|c|c|c|c|c|c|c|c|c|c|c|c|c|}
\hline & Date & 岸 & 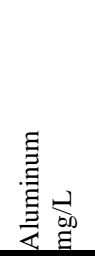 & 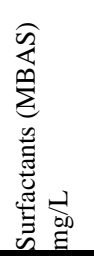 & 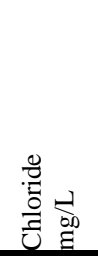 & 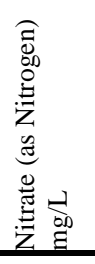 & 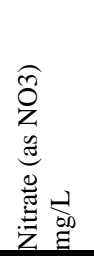 & 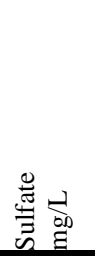 & 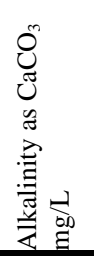 & 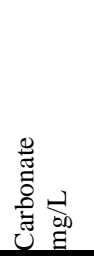 & 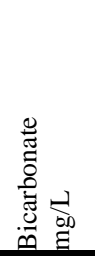 & 홀 & 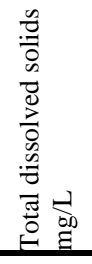 & 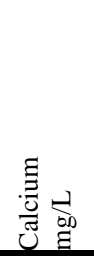 & 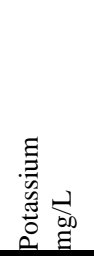 & 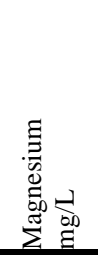 & 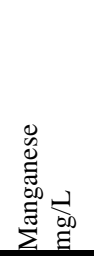 & 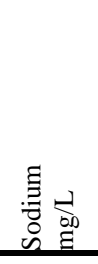 & 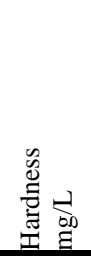 & 罡芯 \\
\hline Detection limit & & 0.05 & 0.05 & 0.05 & 10 & 0.2 & 3 & 20 & 1 & 1 & 1 & 0.05 & 5 & 0.1 & 2 & 0.1 & 0.01 & 1 & 1 & 210 \\
\hline $\begin{array}{l}\text { MCL - } \\
\text { California } \\
\end{array}$ & & $5^{\mathrm{d}}$ & 1 & $0.5^{\mathrm{d}}$ & $500^{\mathrm{d}}$ & & 45 & $500^{\mathrm{d}}$ & & & & $0.3^{\mathrm{d}}$ & $1,000^{\mathrm{d}}$ & & & $0.05^{\mathrm{d}}$ & $0.05^{\mathrm{d}}$ & & & 20000 \\
\hline MCL - Federal & & $5^{\mathrm{d}}$ & $0.2^{\mathrm{d}}$ & $0.5^{\mathrm{d}}$ & $250^{\mathrm{d}}$ & 10 & & $250^{\mathrm{d}}$ & & & & $0.3^{\mathrm{d}}$ & $500^{\mathrm{d}}$ & & & $0.05^{\mathrm{d}}$ & $0.05^{\mathrm{d}}$ & & & \\
\hline \multicolumn{21}{|l|}{$\begin{array}{l}\text { Well ID } \\
\end{array}$} \\
\hline NLF-6 & $6 / 14 / 06$ & -- & -- & -- & -- & -- & -- & -- & -- & -- & -- & -- & -- & -- & -- & -- & -- & -- & -- & -- \\
\hline & $6 / 14 / 06^{\mathrm{a}}$ & -- & -- & -- & -- & -- & -- & -- & -- & -- & -- & -- & -- & -- & -- & -- & -- & -- & -- & -- \\
\hline & $6 / 14 / 06^{\mathrm{b}}$ & -- & -- & -- & -- & -- & -- & -- & -- & -- & -- & -- & -- & -- & -- & -- & -- & -- & -- & -- \\
\hline AS-3A & $6 / 14 / 06$ & ND & ND & ND & -- & -- & -- & -- & 220 & ND & 220 & 0.31 & 510 & 110 & ND & 37 & ND & 87 & -- & $58^{\mathrm{e}}$ \\
\hline AS-3B & $6 / 14 / 06$ & ND & ND & ND & 140 & 3.4 & 15 & 180 & 250 & ND & 250 & ND & 760 & 120 & ND & 48 & ND & 120 & 500 & 420 \\
\hline AS-3C & $6 / 14 / 06$ & ND & ND & ND & 69 & 5.9 & 25 & 160 & 150 & 5.7 & 140 & ND & 540 & 71 & ND & 26 & ND & 130 & 280 & $42^{\mathrm{e}}$ \\
\hline FM-1 $^{\mathrm{C}}$ & & -- & -- & -- & -- & -- & -- & -- & -- & -- & -- & -- & -- & -- & -- & -- & -- & -- & -- & -- \\
\hline FM-7 $^{\mathrm{C}}$ & & -- & -- & -- & -- & -- & -- & -- & -- & -- & -- & -- & -- & -- & -- & -- & -- & -- & -- & -- \\
\hline AS-4 & $6 / 14 / 06$ & ND & 0.49 & ND & 180 & 0.90 & 4.0 & 260 & 460 & ND & 460 & 0.44 & 960 & 120 & ND & 61 & ND & 220 & 550 & $52^{\mathrm{e}}$ \\
\hline Trip Blank & $6 / 14 / 06$ & -- & -- & -- & -- & -- & -- & -- & -- & -- & -- & -- & -- & -- & -- & -- & -- & -- & -- & -- \\
\hline $\begin{array}{l}\text { MCL - Maximur } \\
\text { ND - Non-detect } \\
-- \text { Not required to } \\
{ }^{a} \text { Field duplicate } \\
{ }^{\mathrm{b}} \text { Field blank sam } \\
{ }^{\mathrm{c}} \text { Well was dry du } \\
{ }^{\mathrm{d}} \text { Secondary drin } \\
\mathrm{e}^{\mathrm{e}} \text { Result is less th }\end{array}$ & $\begin{array}{l}\text { m contaminz } \\
\text { able. } \\
\text { analyze or } \\
\text { sample. } \\
\text { iple. } \\
\text { uring } 2006 . \\
\text { king water s } \\
\text { an the samp }\end{array}$ & $\begin{array}{l}\text { el. } \\
\text { e not co }\end{array}$ & lected. & & & & & & & & & & & & & & & & & \\
\hline
\end{tabular}


Table 9-2 Well Depth and Screen Period Interval

\begin{tabular}{llll}
\hline Area & Well ID & Well Depth (ft) & Screen Period Interval (ft) \\
\hline Fuel Oil Spill Site & FM-1 & 106.1 & $90-105$ \\
\hline & FM-7 & 108.56 & $96-106$ \\
\hline Arroyo Seco & AS-3A & 112.58 & $100-110$ \\
\hline & AS-3B & 124.97 & $118-123$ \\
\hline & AS-3C & 157 & $150-155$ \\
\hline Trudell Auto Repair Shop & AS-4 & 28.57 & $15-25$ \\
\hline Navy Landfill & NLF-6 & 94 & $87^{\mathrm{a}}$ \\
\hline${ }^{a}$ Start of screen interva6 & 110 & $87-102$ \\
\hline
\end{tabular}

${ }^{\text {a }}$ Start of screen interval. Length of screen interval is unknown. 


\section{Distribution List}

\section{U.S. Department of Energy}

Karen Agogino (14)

U.S. Department of Energy

Sandia Site Office

P.O. Box 5400, MS 0184

Albuquerque, NM 87185-5400

John Gould

U.S. Department of Energy

Sandia Site Office

P.O. Box 5400, MS 0184

Albuquerque, NM 87185-5400

Jeff Irwin (MS 9221) (CD only)

U.S. Department of Energy

DOE Facility Representative

Sandia National Laboratories, California

Deborah Griswold (2)

U.S. Department of Energy

NNSA Service Center (EPD)

P.O. Box 5400

Albuquerque, NM 87185-5400

Connie Soden

U.S. Department of Energy

NNSA Service Center

Pennsylvania \& H Street

Kirtland Air Force Base

Albuquerque, NM 87185

Michael Thompson

U.S. Department of Energy

NA-17/Forrestal Bldg

1000 Independence Ave, S.W.

Washington, D.C. 20585

Richard Thorpe

U.S. Department of Energy

NA-171/Germantown Bldg 1000 Independence Ave, S.W.

Washington, D.C. 20585-1290
Russell Shearer

U.S. Department of Energy

Chief Deputy for Enforcement and Technical

Matters

HS-1/Forrestal Bldg

1000 Independence Ave., S.W.

Washington, CA 20585

Alice Williams

U.S. Department of Energy

Director Office of Environmental

Projects and Operations

NA-56/ Forrestal Bldg

1000 Independence Ave, S.W.

Washington, D.C. 20585

Robert Goldsmith

U.S. Department of Energy

Director Office of Operations Oversight

EM-62/Cloverleaf Building

1000 Independence Ave., S.W.

Washington, D.C. 20585-2040

Ross Natoli (3)

U.S. Department of Energy

HS-32/Forrestal Bldg

1000 Independence Ave, S.W.

Washington, D.C. 20585

Ray Hardwick

U.S. Department of Energy

MA-50/270 Corporate Square Building

1000 Independence Ave, S.W.

Washington, D.C. 20585-0270

Glenn Podonsky

U.S. Department of Energy

HS-1/Forrestal Bldg

1000 Independence Ave, S.W.

Washington, D.C. 20585

Walter Warnick

U.S. Department of Energy

SC-33, Director Office of Scientific

And Technical Information

19901 Germantown Road

Germantown, MD 20874 
Norbert Golchert

Argonne National Laboratory

9700 S. Cass Avenue

Building 200, Room B-11

Argonne, IL 60439

Roger Dirkes

Battelle Pacific Northwest Laboratories

P.O. Box 999

Richland, WA 99352

Eva Hickey

Battelle Pacific Northwest Laboratories

P.O. Box 999, MS K-3-66

Richland, WA 99352

Michael Ruggieri

Lawrence Berkeley National Laboratory

One Cyclotron Road

Berkeley, CA 94720

Terry Morgan

Los Alamos National Laboratory

Environment and Remediation Support

Services Division

P.O. Box 1663, MS-M992

Los Alamos, NM 87545

Joan Hughes

Oak Ridge National Laboratory

P.O. Box 2008

Oak Ridge, TN 37831

Sharon Thompson

Oak Ridge National Laboratory

P.O. Box 2008

Oak Ridge, TN 37831

Jim Heffner

Savannah River Site

Environmental Permitting and Monitoring

Building 735-B

Aiken, SC 29808

Don Cossairt

Fermilab

P.O. Box 500, MS 119 (WH 7E)

Batavia, IL 60510
Ellen Raber (L-626)

Lawrence Livermore National Laboratory

7000 East Avenue

Livermore, CA 94550

William Hoppes (L-627)

Lawrence Livermore National Laboratory

7000 East Avenue

Livermore, CA 94550

LLNL Public Information Office (L-790)

Lawrence Livermore National Laboratory

7000 East Avenue

Livermore, CA 94550

\section{Other Federal Agencies}

Richard Lessler

U.S. Environmental Protection Agency

Region IX

75 Hawthorne Street

San Francisco, CA 94105

The Honorable Ellen Tauscher

U.S. House of Representatives

California $10^{\text {th }}$ District

1801 N. California, Suite 103

Walnut Creek, CA 94596

The Honorable Ellen Tauscher

U.S. House of Representatives

California $10^{\text {th }}$ District

1239 Longworth House Building

Washington DC 20515

\section{State and Local Agencies}

Edgar D. Bailey

California Department of Health Services

Radiologic Health Branch

P.O. Box 997414, MS 7610

Sacramento, CA 95899-7414

Stephen Woods

California Department of Health Services

Radiologic Health Branch

P.O. Box 997414, MS 7610

Sacramento, CA 95899-7414 
Stephen Hsu

California Department of Health Services

Radiologic Health Branch

P.O. Box 997414, MS 7610

Sacramento, CA 95899-7414

J. Wong

California Department of Health Services

Environmental Management Branch

2151 Berkeley Way, Room 133

Berkeley, CA 94704

Devender Narala

California Regional Water Quality Control

Board

San Francisco Bay Region

1515 Clay Street

Oakland, CA 94612

S. Gittings

Livermore Water Reclamation Plant

101 West Jack London Boulevard

Livermore, CA 94550

D. Greenwood

Livermore Water Reclamation Plant

101 West Jack London Boulevard

Livermore, CA 94550

Kelly Wee

Director of Compliance and Enforcement

Bay Area Air Quality Management District

939 Ellis Street

San Francisco, CA 94109

Robert Weston

Alameda County

Health Care Services Agency

Department of Environmental Health Services

1131 Harbor Bay Parkway

Alameda, CA 94501

Daniel Murphy

California Environmental Protection Agency

Department of Toxic Substances Control

Region 2, Facility Permitting Branch

700 Heinz Avenue, Suite 200

Berkeley, CA 94710
Mike Miller

Public Services Director

City of Livermore

3500 Robertson Park Road

Livermore, CA 94550

Linda Barton

City Manager

City of Livermore

1052 S. Livermore Avenue

Livermore, CA 94550

The Honorable Guy Houston

California State Assembly

$15^{\text {th }}$ District

Capitol Building, Room 4208

Sacramento, CA 95814

The Honorable Guy Houston

California State Assembly

$15^{\text {th }}$ District

1365 Chestnut Street, Suite A

Livermore, CA 94550

Scott Haggerty

Supervisor District 1

Alameda County Board of Supervisors

1221 Oak Street, Suite 536

Oakland, CA 94612

The Honorable Marshall Kamena

Mayor of Livermore

1052 South Livermore Avenue

Livermore, CA 94550

The Honorable Tom Torlakson

California State Senate

$7^{\text {th }}$ District

State Capitol Building, Suite 5061

Sacramento, CA 95814

The Honorable Tom Torlakson

California State Senate

$7^{\text {th }}$ District

2801 Concord Blvd.

Concord, CA 94519 


\section{Individuals and Organizations}

Mike and Ann Mueller

2693 South Vasco Road

Livermore, CA 94550

Marylia Kelley

Tri-Valley CAREs

2528 Old First Street

Livermore, CA 94550

\section{Sandia National Laboratories}

MS 0101

MS 9001

MS 9131

MS 9111

MS 9221

MS 9018

MS 0899

MS 9021

MS 9021
T.O. Hunter, 1

P. J. Hommert, 8000

J. Manchester, 8528 (3)

M.E. Janes, 8528

B. Larsen, 8516 (10)

Central Technical Files, 8945 (2)

Technical Library, 4536 (2)

Classification Office, 8511

Classification Office, 8511

For DOE/OSTI
Internal Notification Only with Web Link

MS 9004

MS 9007

MS 9054

MS 9002

MS 9405

MS 9151

MS 9002

MS 9221

MS 9221

MS 9221

MS 9221

MS 9221

MS 9221

MS 9221

MS 9221

MS 9221

MS 9221

MS 9221

MS 9031

MS 0342

MS 1037

MS 0141

MS 0141

MS 1042

MS 1042

MS 1042

MS 1151

MS 1089

MS 1089

MS 1042
J. Hruby, 8100

D. Henson, 8200

T. Michalske, 8300

P.N. Smith, 8500

R. Carling, 8700

L. Napolitano, 8900

L. Houston, 8500

E. Cull, 8510

G. Shamber, 8516

R. Holland, 8516

L. Gardizi, 8516

A. Leo, 8516

L. Farren, 8516

J. Harris, 8516

M.E. Brynildson, 8516

A. Jackson, 8517

T.B. Garcia, 8517

D. Beyer, 8518

K.C. Olsen, 11600

P. Newman, 10300

B. Brandhuber, 10310

B. Krauss, 11000

A. Blumberg, 11100

C. Fink, 10331

S. Salinas, 10331

H.A. Hwang, 10331

J.J. Thompson, 10339

J.P. Freshour, 6765

F.B. Nimick, 6140

T.W. Cooper, 10333 